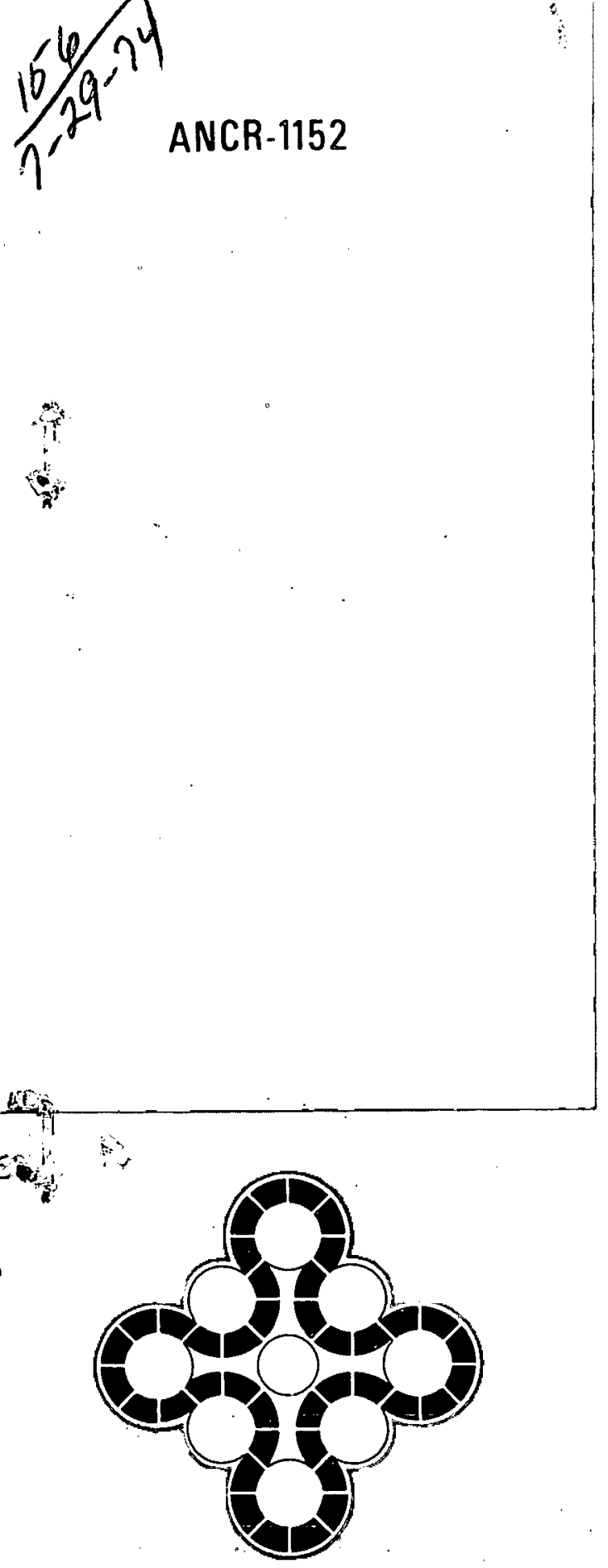

UC-78

\title{
'EXPERIMENT DATA REPORT \\ FOR 1-1/2-LOOP SEMISCALE SYSTEM ISOTHERMAL TEST 1009
}

E.M. Feldman

\section{Aerojet nuclear Company}

\author{
NATIONAL REACTOR TESTING STATION \\ Idaho Falls, Idaho - 8340 I
}

\section{DATE PUBLISHED-JUNE 1974}

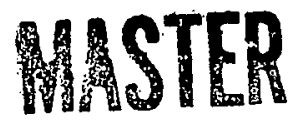

\section{U. S. ATOMIC ENERGY COMMISSION}

IDAHO OPERATIONS OFFICE UNDER CONTRACT AT(10-1)-1375 


\section{DISCLAIMER}

This report was prepared as an account of work sponsored by an agency of the United States Government. Neither the United States Government nor any agency Thereof, nor any of their employees, makes any warranty, express or implied, or assumes any legal liability or responsibility for the accuracy, completeness, or usefulness of any information, apparatus, product, or process disclosed, or represents that its use would not infringe privately owned rights. Reference herein to any specific commercial product, process, or service by trade name, trademark, manufacturer, or otherwise does not necessarily constitute or imply its endorsement, recommendation, or favoring by the United States Government or any agency thereof. The views and opinions of authors expressed herein do not necessarily state or reflect those of the United States Government or any agency thereof. 


\section{DISCLAIMER}

Portions of this document may be illegible in electronic image products. Images are produced from the best available original document. 


\section{DISCLAIMER}

This report was prepared as an account of work sponsored by an agency of the United States Government. Neither the United States Government nor any agency Thereof, nor any of their employees, makes any warranty, express or implied, or assumes any legal liability or responsibility for the accuracy, completeness, or usefulness of any information, apparatus, product, or process disclosed, or represents that its use would not infringe privately owned rights. Reference herein to any specific commercial product, process, or service by trade name, trademark, manufacturer, or otherwise does not necessarily constitute or imply its endorsement, recommendation, or favoring by the United States Government or any agency thereof. The views and opinions of authors expressed herein do not necessarily state or reflect those of the United States Government or any agency thereof. 


\section{DISCLAIMER}

Portions of this document may be illegible in electronic image products. Images are produced from the best available original document. 


$$
\begin{gathered}
\text { Printed In the United States of America } \\
\text { Available from } \\
\text { National Technical Information Service } \\
\text { U. S. Department of Commerce } \\
5285 \text { Port Royal Road } \\
\text { Springfield, Virginia } 22151
\end{gathered}
$$

\section{LEGAL NOTICE}

This report was prepared as an account of work sponsored by the United States Government. Neither the United States nor the United States Atomic Energy. Commission: nor any of their employees, nor any of the ir contractors, subcontractors, or their employees; makes any warranty, express or implied, or assumes ary legal liability or responsibility for the accuracy, conpleteness or usefulness of any information, apparatus, product or process disclosed, or represents that its. use would not infringe privately owned rights. 
EXPERIMENT DATA REPORT FOR 1-1/2-LOOP SEMISCALE

SYSTEM ISOTHERMAL TEST 1009

by

E. M. Fèldman

\begin{abstract}
This report was prepared as an account of work sponsored by the prepared as an account of work the United States nor the United States Atomic Energy Comister Cominission, nor any of their empioyees, nor any of their contractors, subcontractors, or their empioyees, makes any warranty, express or implied, or assumes any legal liability or responsibility for the accuracy, completeness or usefulness of any information, apparatus, product or process disclosed, or represents that its use would not infringe privately owned rights.
\end{abstract}

\title{
AEROJET NUCLEAR COMPANY
}

Date Published - June 1974

PREPARED FOR THE U. S. ATOMIC ENERGY COMMISSION IDAHO OPERATIONS OFFICE UNDER CONTRACT NO. AT(10-1)-1375 


\begin{abstract}
ABSTR.ACT
Recorded test data are presented for Test 1009 of the isothermal portion of the Semiscale Blowdown and Emergency Core Cooling (ECC) Project. These data represent the results of the first isothermal test utilizing an enlarged downcomer gap (1.69 inches) in the pressure vessel to investigate general system hydraulic response with simulated ECC injection. The data, presented in the form of composite graphs in engineering units, have been analyzed only to the extent necessary to assure that they are reasonable and correct. The intent of this report is to make avaiiable the uninterpreted data from Test 1009 for use by others and for support of subsequent interpretive reports and analysis.
\end{abstract}




\section{SUMMARY}

Test 1009 was performed in the isothermal portion of the Semiscale Blowdown and Emergency Core Cooling (ECC) Project conducted by Aerojet Nuclear Company for the Atomic Energy Commission. This decompression test utilized an enlarged downcomer gap (1.69 inches) with a 100\% break area nozzle. The experimental system consisted of a pressure vessel with simulated reactor internals; an operating loop with pump, steam generator, and pressurizer; a blowdown loop with a simulated pump, a simulated steam generator, and rupture assemblies; and a pressure suppression system with header and pressure suppression tank.

Test 1009 was initiated from isothermal conditions of $2245 \mathrm{psig}$ and $575^{\circ} \mathrm{F}$ by a simulated instantaneous large cold leg pipe break. Accumulators injected simulated ECC into the cold legs of the operating and blowdown loops.

In general, instrumentation used in Test 1009 functioned as intended and data loss was

minimal. Of more than 150 measurements attempted during the test, more than $90 \%$ were accomplished. The data appear to be satisfactory for subsequent analysis. 


\section{CONTENTS}

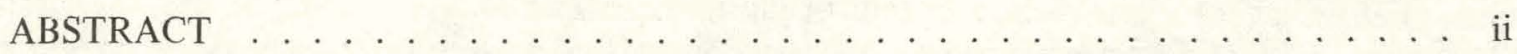

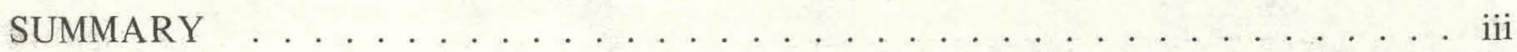

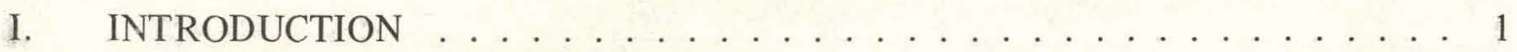

II. SYSTEM AND CONDITIONS FOR TEST $1009 \ldots \ldots \ldots \ldots \ldots \ldots$

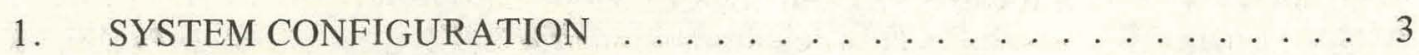

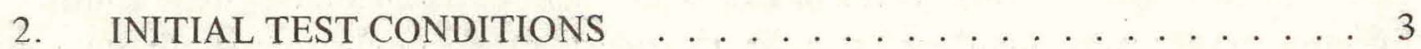

3. EVENTS AND CONDITIONS FOLLOWING BLOWDOWN
INITIATION $\ldots \ldots \ldots \ldots \ldots \ldots \ldots \ldots \ldots \ldots \ldots \ldots \ldots \ldots \ldots \ldots \ldots \ldots \ldots$

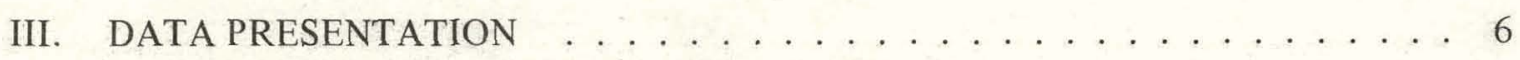

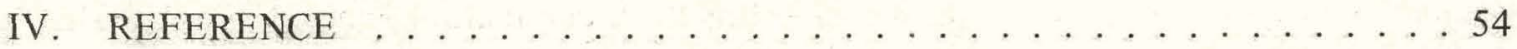

\section{FIGURES}

1. $1-1 / 2$-loop semiscale system and instrumentation - isometric ........ 7

2. 1-1/2-loop semiscale system and instrumentation-schematic . . . . . . 8

3. Pressure vessel -- cross-sectional view showing instrumentation . . . . . . . . . 9

4. Pressure vessel - isometric showing instrumentation . . . . . . . . . . 10

5. Fluid temperatures in operating loop .................. 16

6. Fluid temperatures in blowdown loop ... . . . . . . . . . . 16

7. Fluid temperatures in pressure suppression system . . . . . . . . . 17

8. Fluid temperatures in lower plenum at thermocouple rack . . . . . . . . . 17

9. Fluid temperatures in downcomer gap and outlet plenum . . . . . . . 18

10. Fluid temperatures in downcomer gap and outlet plenum (expansion of Figure 9 for TF-214, TF-217, TF-219, TF-269, and TF-211) . . . . . . . 18 
11. Fluid temperatures in downcomer gap (expansion of Figure 9 for TF-48C-180, TF-215, TF-245, $\mathrm{I} \mathrm{H}-247$, and TF-268) . . . . . . . . . 19

12. Fluid temperatures in ECC lines from blowdown loop accumulator tank and operating loop accumulator tank . . . . . . . . . . . . . . . 19

13. Metal temperatures in core barrel ................... 20

14. Metal temperatures in vessel wall . . . . . . . . . . . . . . . 20

15. Metal temperatures in lower plenum vessel wall . . . . . . . . . . 21

16. Metal temperatures in operating loop hot leg Spool $1 \ldots \ldots$. . . . . . . 21

17. Metal temperatures in operating loop cold leg Spool $19 \ldots \ldots 22$

18. Metal temperatures in operating loop cold leg Spool $22 \ldots . . . . . . . .22$

19. Metal temperatures in blowdown loop ................ . . 23

20. Momentum flux from drag discs in operating loop hot leg . . . . . . . 23

21. Momentum flux from drag discs in operating loop cold leg . . . . . . . . . 24

22. Momentum flux from drag discs in blowdown loop . . . . . . . . . . 24

23. Momentum flux from drag discs at core barrel inlet . . . . . . . . . 25

24. Volumetric flow rate from turbine meters in operating loop . . . . . . . 25

25. Volumetric flow rate from turbine meter in blowdown loop hot leg . . . . . . 26

26. Volumetric flow rate from turbine meter at core barrel inlet . . . . . . . . 26

27. Volumetric flow rate from turbine meter at pressurizer outlet . . . . . . . . 27

28. Volumetric flow rate from ECC accumulator tanks in operating and blowdown loops (turbine meters) . . . . . . . . . . . . . . 27

29. Mass flow rate in operating loop hot leg Spool 1 . . . . . . . . . . . 28

30. Mass flow rate in operating loop at pump discharge (Spool 19) . . . . . . . . 28

31. Mass flow rate in operating loop cold leg Spool 22 . . . . . . . . . . . . . . . . 29

32. Mass flow rate in operating loop Spools 5 and 15 . . . . . . . . . . . 29

33. Mass flow rate in blowdown loop Spool $70 \ldots \ldots$. . . . . . . . . 30 
34. Mass flow rate in blowdown loop Spools 50 and $76 \ldots \ldots$. . . . . . . 30

35. Mass flow rate at core barrel inlet ..................... 31

36. Fluid density in operating loop hot leg . . . . . . . . . . 31

37. Fluid density at operating loop pump inlet and outlet . . . . . . . . 32

38. Fluid density in operating loop cold leg . . . . . . . . . . . 32

39. Fluid density in blowdown loop ... . . . . . . . . . . 33

40. Fluid density in vessel ... . . . . . . . . . . . . . . 33

41. Pressure in operating loop . . . . . . . . . . . . . 34

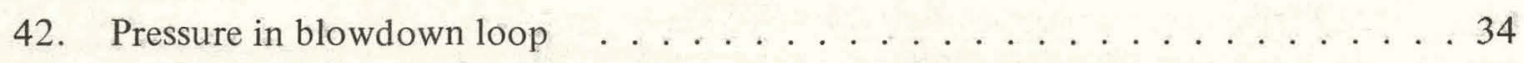

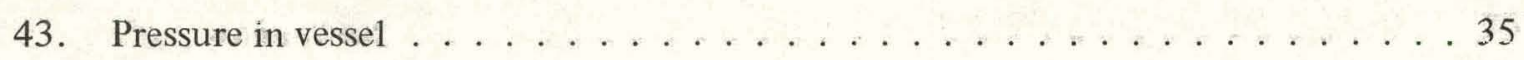

44. Pressure in pressure suppression system ... . . . . . . . 35

45. Pressure at hot leg stub in upper plenum (LOFT free field

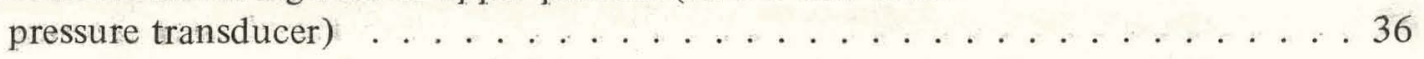

46. Pressure of ECC in accumulators ...................... 36

47. Differential pressure, operating loop hot leg (DP-1-5) . . . . . . . 37

48. Differential pressure across steam generator (DP-5-13) . . . . . . 37

49. Differential pressure across pump suction orifice (DP-8-13) . . . . . . 38

50. Differential pressure across operating loop pump inlet (DP-13-15) . . . . . 38

51. Differential pressure across operating loop pump (DP-19-15) . . . . . . . . . 39

52. Differential pressure across operating loop pump, low range $($ DP-19-15L) . . . . . . . . . . . . . . . . . 39

53. Differential pressure across operating loop cold leg (DP-19-22) . . . . . . . 40

54. Differential pressure between cold leg and lower plenum (DP-22-255) . . . . 40

55. Differential pressure across core $($ DP-255-207) . . . . . . . . . . 41

56. Differential pressure across upper portion of downcomer

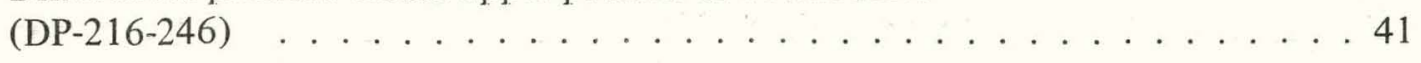


57. Differential pressure across middle portion of downcomer

(DP-246-249)

58. Differential pressure across lower portion of downcomer (DP-249-255)

59. Differential pressure across lower plenum (DP-261-255) . . . . . . . . \3

60. Differential pressure across vessel (DP-LOFT) . . . . . . . . . . . . . 43

61. Differential pressure between vessel upper plenum and blowdown loop hot leg (DP-207-70) . . . . . . . . . . . . . . . . . . 44

62. Differential pressure between vessel inlet annulus and blowdown loop cold leg (DP-264-50) . . . . . . . . . . . . . . . . 44

63. Differential pressure between inner disc cavities (DP-52-62) . . . . . . . . 45

64. Differential pressure across blowdown loop hot leg nozzle (DP-76-61) . . . . . 45

65. Differential pressure between simulated pump and throat of blowdown loop hot leg nozzle $($ DP-76-HN2) . . . . . . . . . . . 46

66. Differential pressure across simulated pump (DP-96-76) . . . . . . . . 46

67. Differential pressure across simulated steam generator (DP-70-96) . . . . . . 47

68. Differential pressure across blowdown loop cold leg nozzle diverging section (DP5-HN2-HN4) . . . . . . . . . . . . . . . 47

69. Differential pressure across blowdown loop hot leg nozzle diverging section (DP6-HN2-HN4) . . . . . . . . . . . . . . 48

70. Differential pressure across blowdown loop hot leg nozzle, Station $61($ DP-HN4-61) . . . . . . . . . . . . . . . . . . . . 48

71. Differential pressure between vessel upper plenum and pressure suppression tank vapor chamber (DP-207-89) . . . . . . . . . . . . . . 49

72. Differential pressure between pressure suppression header and pressure suppression tank vapor chamber (DP-81-89) . . . . . . . . . . . . . 49

73. Differential pressure between pressure suppression header and pressure suppression tank downcomer entrance (DP-81-85) . . . . . . . . . . 50

74. Liquid level in pressure suppression tank (LL-PSS) . . . . . . . . . . . . . 50

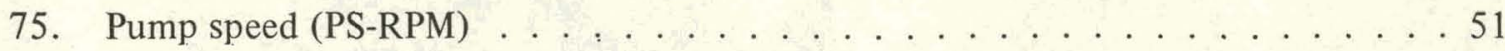

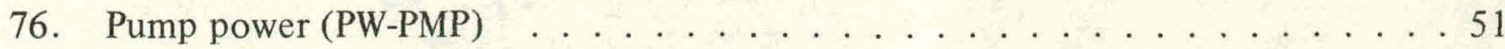




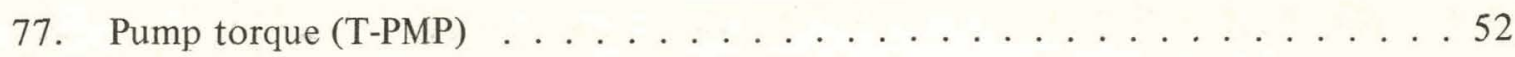

78. Flow direction in downcomer gap $(\mathrm{S}-271) \ldots \ldots \ldots \ldots$

79. Displacement of pressure suppression system . . . . . . . . . . 53

\section{TABLES}

I. Conditions at Blowdown Initiation .............. 4

II. Water Chemistry Prior to Blowdown . . . . . . . . . . . . . 4

III. Sequence of Events Following Blowdown Initiation . . . . . . . . . . 5

IV. Data Presentation for Isothermal Test $1009 \ldots \ldots \ldots \ldots$ 


\section{EXPERIMENT DATA REPORT FOR 1-1/2-LOOP SEMISCALE \\ SYSTEM ISOTHERMAL TEST 1009}

\section{INTRODUCTION}

The isothermal blowdown test program is part of the Semiscale Blowdown and Emergency Core Cooling (ECC) Project conducted by Aerojet Nuclear Company. The project is part of an overall AEC-sponsored research and development program directed at (a) quantifying the physical process controlling system behavior during a postulated loss-of-coolant accident (LOCA) in a pressurized water reactor (PWR), and (b) providing an experimental data base for assessing reactor safety evaluation models.

The 1-1/2-loop semiscale system in which the isothermal test program was conducted includes both an intact operating loop and a broken, or blowdown, loop. The operating loop simulates three unbroken loops of a PWR, and the blowdown loop simulates one broken loop of a PWR. Relative to previous experimental systems, the 1-1/2-loop semiscale system provides a source of more representative coupled-system response data from which to obtain a correspondingly more comprehensive understanding of the thermal and hydraulic processes during an LOCA.

The major emphasis in the isothermal blowdown experiments was on ECC delivery. Test 1009 was conducted with ECC injection and without a core barrel filler piece. The removal of the core barrel filler piece resulted in the largest possible downcomer gap (1.69 inches) relative to the other semiscale isothermal tests. Test 1009 provided data for determining system response to a variation in downcomer gap.

The test configuration and conditions for Test 1009 are as follows:

(1) Initial isothermal conditions were 2245 psig and $575^{\circ} \mathrm{F}$

(2) An enlarged downcomer gap size of 1.69 inches was used

(3) The standard (long) lower plenum configuration ( $/ \mathrm{D}=2.8: 1$ ) was used with the thermal shield installed

(4) The $100 \%$ break area nozzles were used

(5) ECC injection into the cold leg of the operating and blowdown loops was initiated at a primary system pressure of $\sim 600 \mathrm{psig}$

(a) Operating loop accumulator injection flow was $\sim 49 \mathrm{gpm}$ average 
(b) Blowdown loop accumulator injection flow was $\sim 10 \mathrm{gpm}$ average.

The purpose of this report is to present the test data in an uninterpreted, but readily usable, form for use by the nuclear community in advance of detailed analysis and interpretation. Section II briefly describes the system configuration and initial test conditions that are applicable to Test 1009. Section III presents the data graphs and provides comments and supporting information necessary for interpretation of the data.

Reference 1 is recommended as an additional source of information regarding the isothermal experimental system and program; test conditions and procedures; instrument locations, nomenclature, and accuracies; and methods of obtaining and processing the data. 


\section{SYSTEM AND CONDITIONS FOR TEST 1009}

The system configuration and initial test conditions that are specific to Test 1009 are presented.

\section{SYSTEM CONFIGURATION}

The 1-1/2-loop isothermal semiscale system used for Test 1009 consisted of a pressure vessel with internals; an operating loop with a steam generator, pump, and pressurizer; a blowdown loop with a simulated steam generator, a simulated pump, and two rupture assemblies; and a pressure suppression tank and a header.

For Test 1009 the standard lower plenum (L/D $=2.8: 1$ ) was used. This plenum consists of the standard (long) lower head and the downcomer filler extension. The lower plenum was thermally insulated with the thermal shield, which consists of the thermal sleeve and the bottom thermal liner plate. The vessel downcomer filler piece was removed to provide a 1.69-inch downcomer gap for the test. The system was subjected to a double-ended offset cold leg break by means of two rupture disc assemblies each employing $100 \%$ break area nozzles.

\section{INITIAL TEST CONDITIONS}

Conditions in the semiscale system at initiation of blowdown and the primary system water chemistry prior to blowdown are given in Tables I and II, respectively. 
TABLE I

CONDITIONS AT BLOWDOWN INITIATION

\begin{tabular}{lc}
\hline \multicolumn{1}{c}{ Conditions } & Test 1009 \\
\hline Core outlet temperature $\left({ }^{\circ} \mathrm{F}\right)$ & 575 \\
System flow rate (gpm) & 173 \\
System pressure at vessel outlet (psig) & 2245 \\
Pump differential pressure (psid) & 41 \\
Suppression tank water level (in.) & 47.5 \\
Suppression tank water temperature ( $\left.{ }^{\circ} \mathrm{F}\right)$ & Atmospheric \\
Suppression tank pressure & 0.52 \\
Pressurizer water volume (ft ${ }^{3}$ ) & 1120 \\
Operating loop accumulator pressure (psig) & 600 \\
Blowdown loop accumulator pressure (psig) & \\
\hline
\end{tabular}

TABLE II

WATER CHEMISTRY PRIOR TO BLOWDOWN

\begin{tabular}{lc}
\hline \multicolumn{1}{c}{ Conditions } & Test 1009 \\
\hline $\mathrm{pH}$ & 8.3 \\
Chlorides (ppm) & 0.1 \\
Conductivity (urhos/cm) & 20 \\
Suspended solids (ppm) & 2.1 \\
$\mathrm{H}_{2}(\mathrm{cc} / 1)$ & 0.5 \\
$\mathrm{O}_{2}(\mathrm{cc} / 1)$ & 19.2 \\
$\mathrm{~N}_{2}(\mathrm{cc} / 1)$ & 90.9 \\
$\mathrm{CO}_{2}(\mathrm{cc} / 1)$ & 0.03 \\
$\mathrm{Total}_{\mathrm{gas}}(\mathrm{cc} / 1)$ & 111.0 \\
\hline
\end{tabular}




\section{EVENTS AND CONDITIONS FOLLOWING BLOWDOWN INITIATION}

The sequence of events following blowdown initiation is presented in Table III. After coolant injection was terminated and blowdown was over, the lower plenum was found to contain 9.5 gal of water.

TABLE III

SEQUENCE OF EVENTS FOLLOWING BLOWDOWN INITIATIOIN

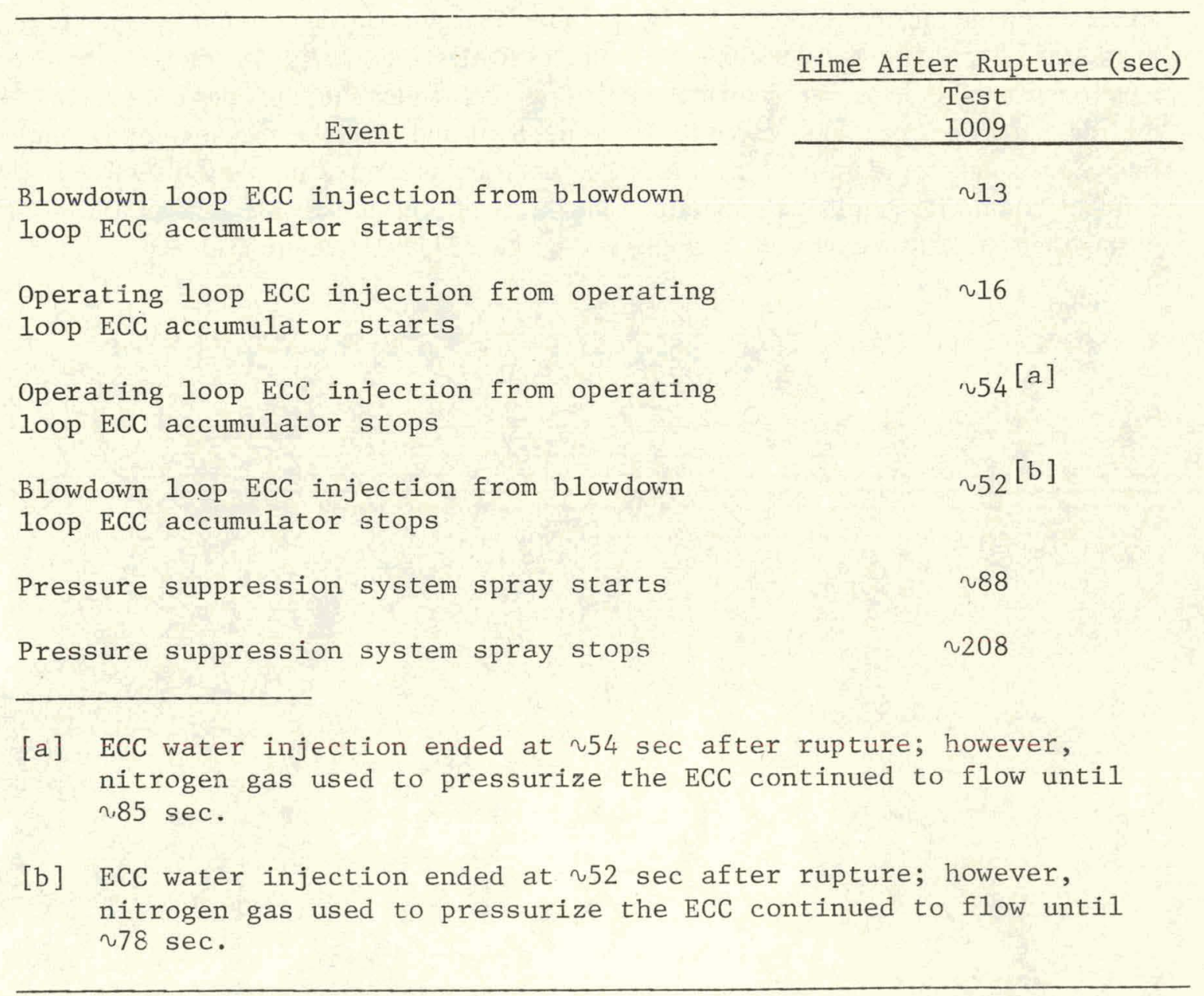




\section{DATA PRESENTATION}

The data from semiscale isothermal Test 1009 are presented with brief comment. Processing and analysis have been performed only to the extent necessary to obtain appropriate engineering units and to assure that the data are reasonable and correct. In all cases, in converting transducer output to engineering units, a homogeneous fluid was assumed. Further interpretation and analysis should consider that sudden decompression processes such as those occurring in the isothermal tests may have subjected the measurement devices to nonhomogenous fluid conditions.

Figures 1 through 4 and Table IV provides supporting information for interpretation of the data graphs shown in Figures 5 through 79. Figures 1 through 4 show the locations of all measurements in the isothermal system. Table IV groups the measurements taken during Test 1009 according to measurement type; identifies the specific measurements, their locations, and the range over which the data are considered valid; provides brief comments regarding the data; and references the measurements and comments to the corresponding figure on which the data are presented. The data are presented in many instances in the form of composite graphs to facilitate comparison of a given variable at several locations during the test. Zero seconds on all graphs is the time of blowdown initiation. 

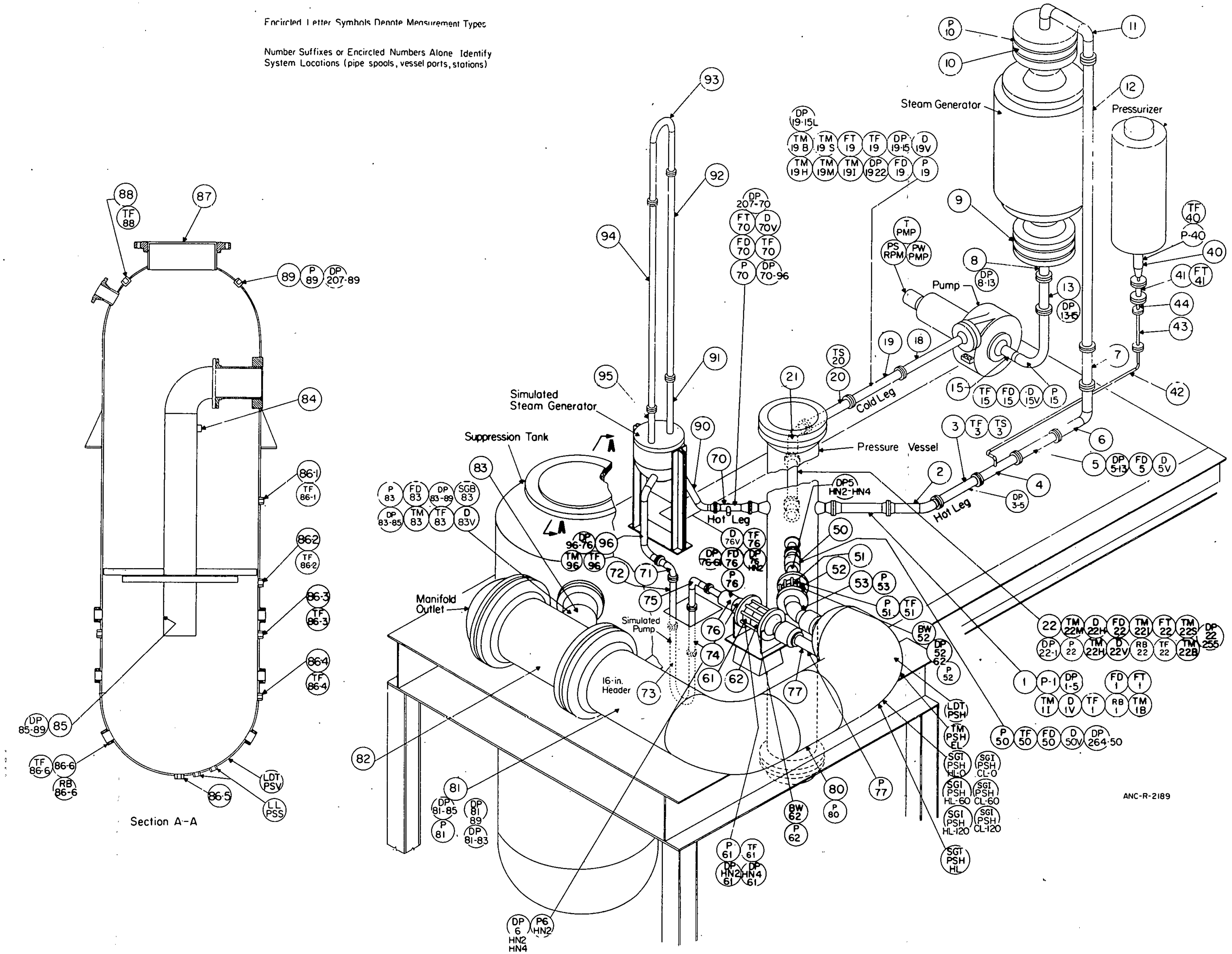

Fig. 1 1-1/2-loop semiscale system and instrumentation -- isometric. 


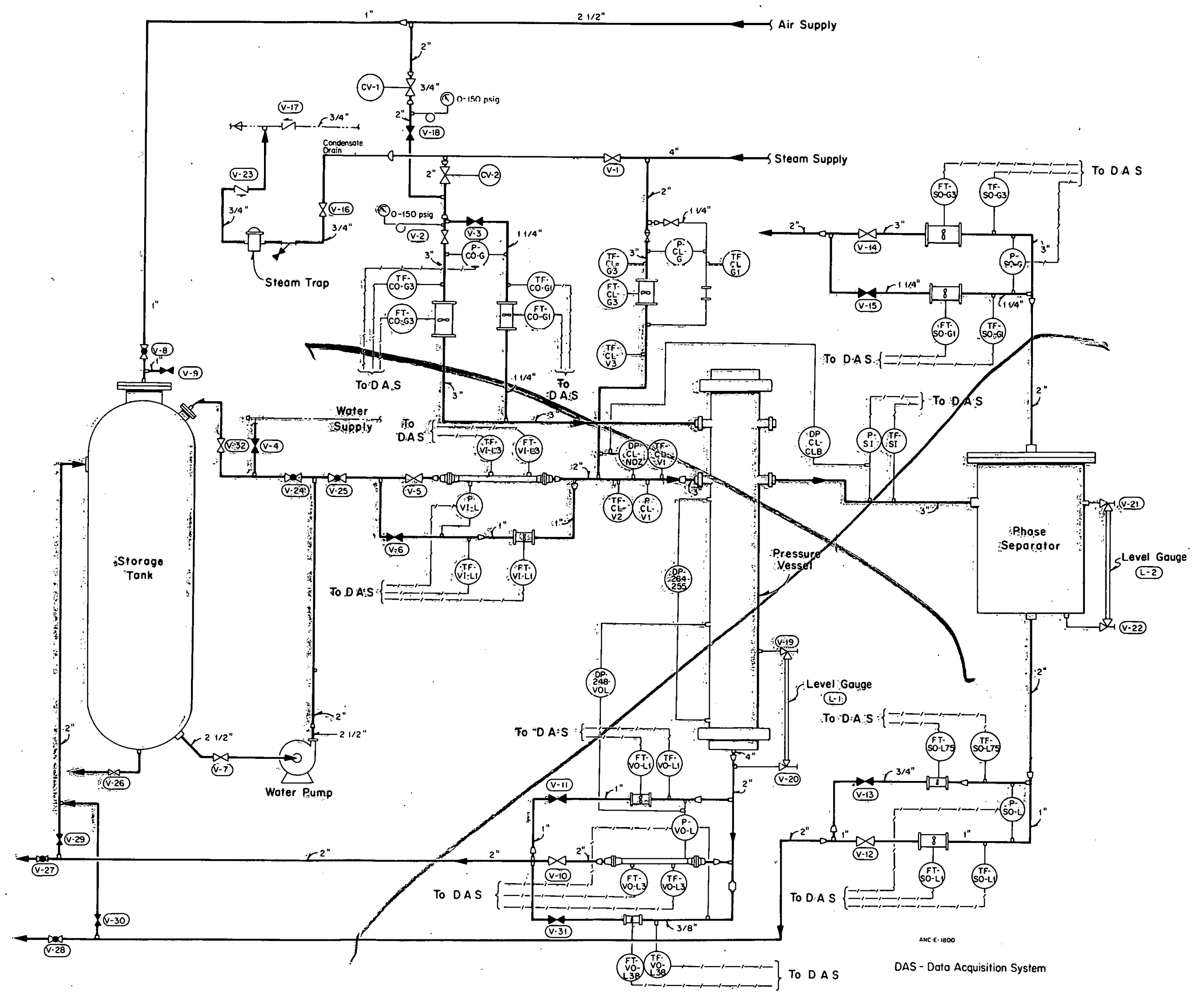

Fig. 2 1/1-2-1oop semiscale system and instrumentation -- schematic. 


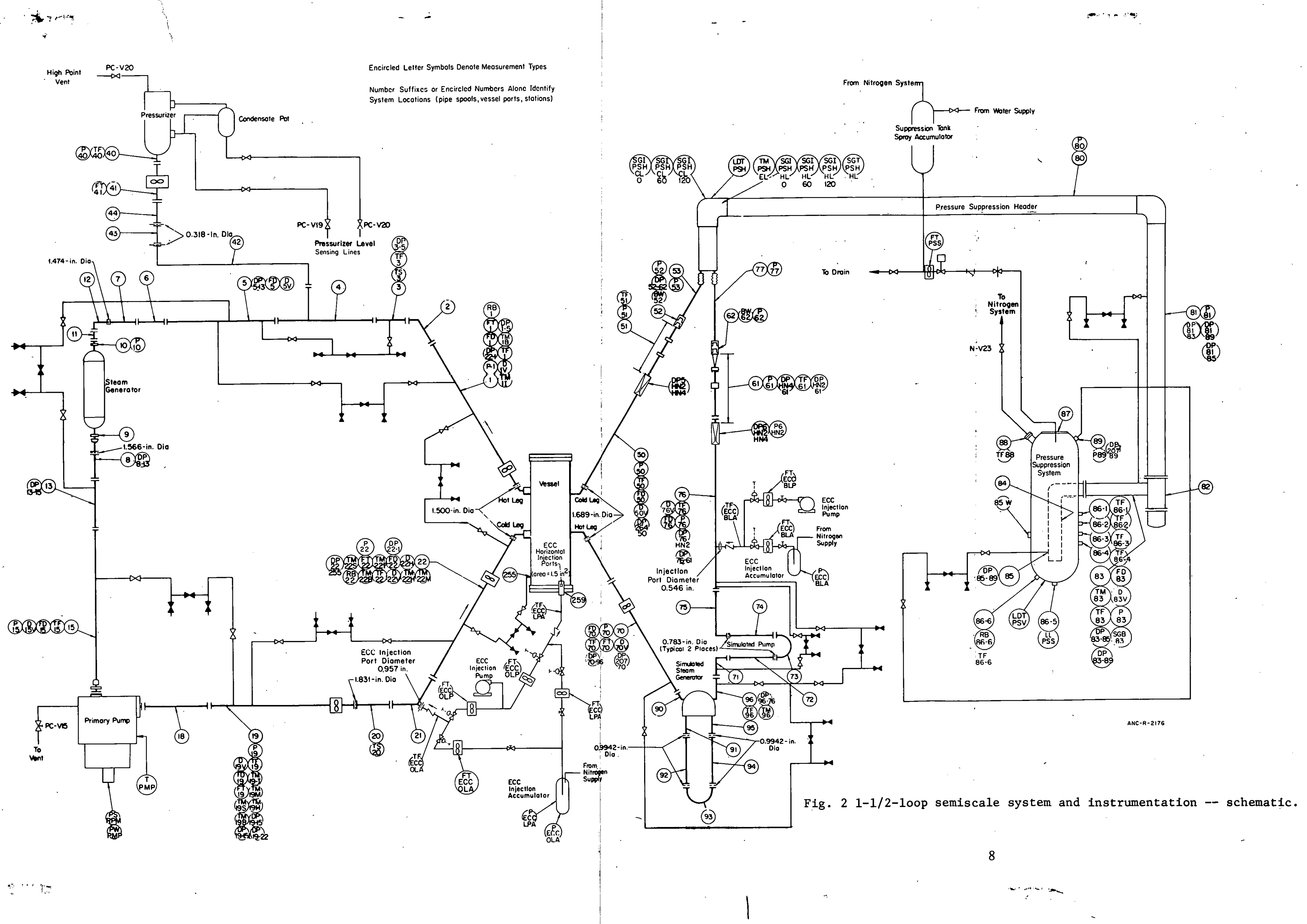




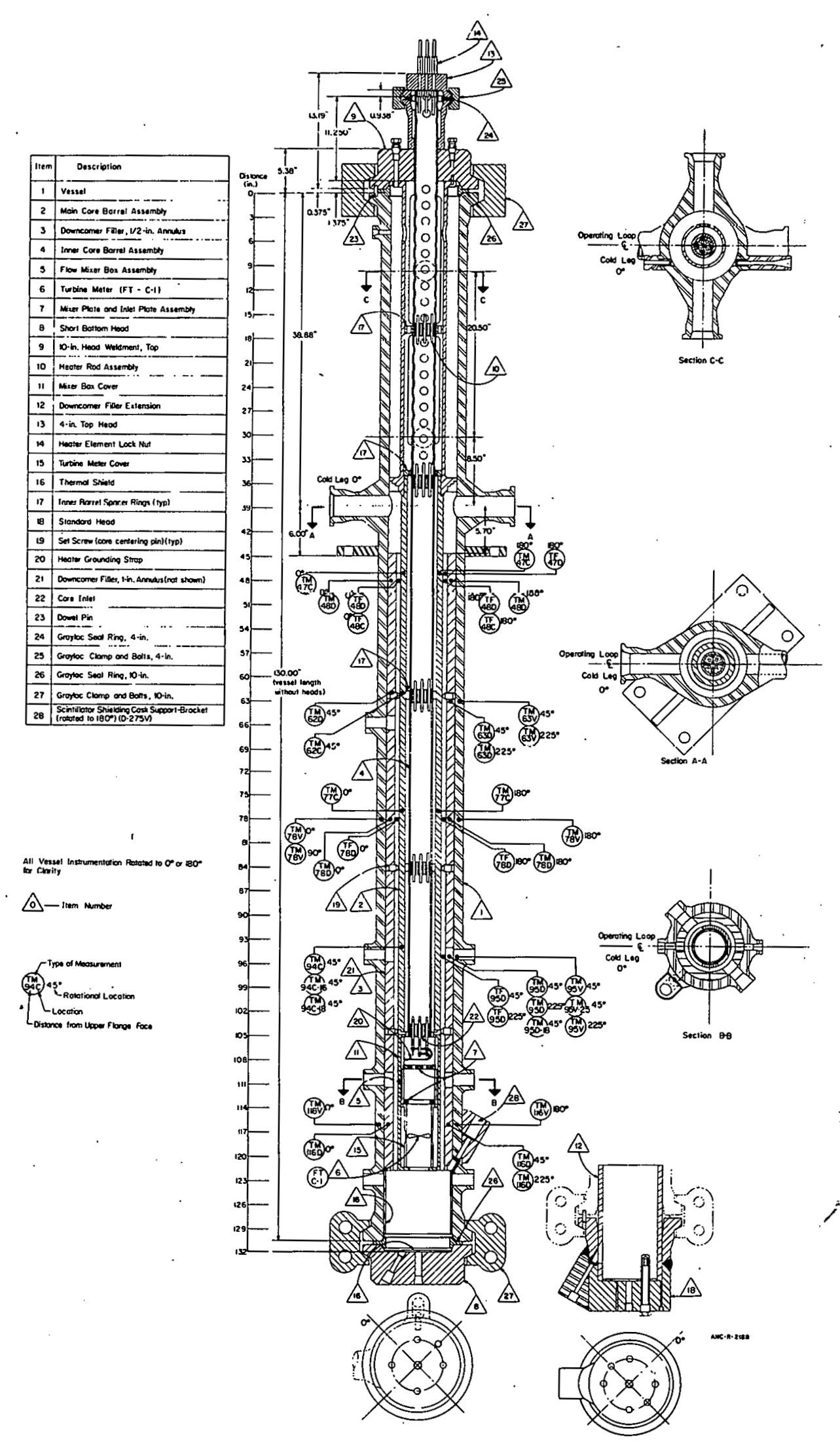

Fig. 3 Pressure vessel -- cross-sectional view showing instrumentation. 


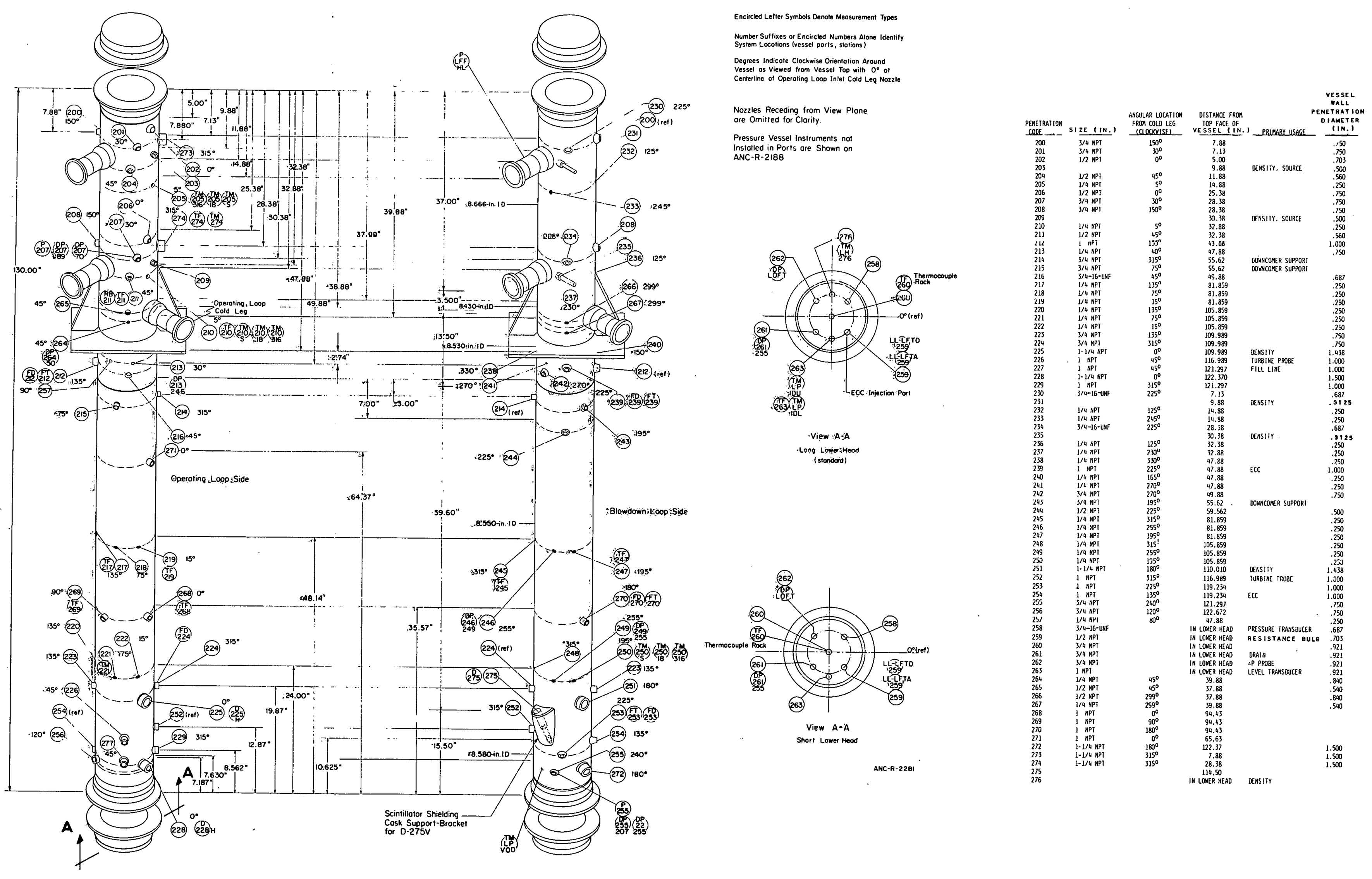

Fig. 4 Pressure vessel -- isometric showing instrumentation. 
TABLE IV

DATA PRESENTATION FOR ISOTHERMAL TEST 1009

TABLE IV

DATA PRESENTATION POR ISOTHERMAL TEST 1009

\begin{tabular}{|c|c|c|c|c|}
\hline Measurement ${ }^{[\mathrm{a}]}$ & Locsicion ${ }^{(b)}$ & Range $^{[c, d]}$ & P1sure & Comment $^{[\mathrm{d}]}$ \\
\hline FLUID TEMPERATURE & & & & $\begin{array}{l}\text { Chromel-Alumel thernocouples; estloated } \\
\text { accuracy to vithin } \pm 7^{\circ} \mathrm{F} \text {. }\end{array}$ \\
\hline Operating Loop & & $33-650^{\circ} \mathrm{F}$ & 5 & \\
\hline $\mathrm{TF}-1$ & Hot leg, Spool 1 & & & \\
\hline TF-1S & Pump suction, Spool 15 & $\cdot$ & & \\
\hline TF-19 & Punp discharge, Spool 19 & & & \\
\hline TF-22 & Cold 1eg, Spool 22 & & & \\
\hline TF -40 & Pressurizer outlet, spool 40 & & & \\
\hline TS-3 & Hot leg, Spool 3 & & & TS-3 is a shielded thermocouple \\
\hline Blowdown Loop & & $33-650^{\circ} \mathrm{F}$ & 6 & \\
\hline$T F-50$ & Cold leg, Spool so & & & \\
\hline TF-51 & Cold leg downstream of vessel-side nozzle & & & \\
\hline$T F-70$ & Hot leg, Spool 70 & & & \\
\hline$T F-76$ & Cold leg, Spool 76 & & & \\
\hline TF-96 & Simulated steam generator discharge, Spool 96 & & & \\
\hline Pzessure Suppression System & & & 7 & \\
\hline $\mathrm{TF}-86-3$ & Suppresolon Vessel, Station $86-3$ & $33-300^{\circ} \mathrm{F}$ & & - \\
\hline$T F-88$ & $\begin{array}{l}\text { Suppression vessel vapor chamber, } 2 \text { 1nches } \\
\text { from tank wall }\end{array}$ & $33-650^{\circ} \mathrm{F}$ & & \\
\hline RB-86-6 & Suppression vessel water, Stacion $86-6$ & $0-1000^{\circ} \mathrm{F}$ & & $\begin{array}{l}\text { RB-86-6 is a resistance bulb fluid cemperature } \\
\text { detector }\end{array}$ \\
\hline $\begin{array}{l}\text { Lower Plenum (Vertical Ther- } \\
\text { mocouple Rack) }\end{array}$ & 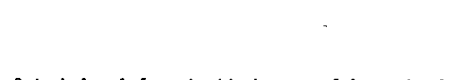 & $33-650^{\circ} \mathrm{F}$ & 8 & $\begin{array}{l}\text { 8ight thermocouples apaced at } 2 \text {-1nch intervals } \\
\text { upward from } 21.75 \text { inches above bottom of the } \\
\text { lower head }\end{array}$ \\
\hline$T F-260-2$ & 2-inch level from Inside botton of lower head & & & \\
\hline TF-260-4 & 4-1nch level from inside bot tom of lower head & & & \\
\hline$T F-260-6$ & 6-1nch level from 1nside botton of lower head & & & \\
\hline$T F-260-8$ & 8-inch level from inside botcom of lower head & & & . \\
\hline $\mathrm{TF}-260-10$ & 10-Inch level from inside bottom of lowes head & & & \\
\hline TF $-260-12$ & 12-inch level from inside bottom of lower head & & & \\
\hline TF-260-14 & 14-1nch level from inside botton of lower head & & & \\
\hline TF-260-16 & 16-1nch level froo Inside botton of lower head & & & \\
\hline TF-263 & In lover plenum head, Station 263 & & & TF-263 falled during Test 1009 \\
\hline Douncomer Gap & & $33-650^{\circ} \mathrm{P}$ & & \\
\hline$T F-48 C-180$ & 248 1nehes, $180^{\circ}$, extend1ng $1 / 8$ 1nch 1nto Eluid & & 9,11 & \\
\hline TF-214 & 55.62 1nches, $315^{\circ}$ & & 9,10 & \\
\hline TF-215 & 55.62 inches, $75^{\circ}$ & & 9, 11 & \\
\hline TF-217 & 81.86 Inches, $135^{\circ}$ & & 9,10 & \\
\hline TF-219 & 81.86 1nches, $15^{\circ}$ & & 9,10 & $\cdot$ \\
\hline TF-245 & 81.86 1nches, $315^{\circ}$ & & 9,11 & \\
\hline $\mathrm{TP}-247$ & 81.86 1nches, $195^{\circ}$ & & 9,11 & \\
\hline TF-268 & 94.43 1nches, $0^{\circ}$ & & 9,11 & \\
\hline TF-269 & 94.43 Inches, $90^{\circ}$ & & 9,10 & \\
\hline Outlet Plenum & & $33-650^{\circ} \mathrm{F}$ & & \\
\hline $\mathrm{TP}-211$ & 32.4 1nches, $45^{\circ}$ & & 9,10 & \\
\hline Ecc System - & & $33-300^{\circ} \mathrm{F}$ & 12 & \\
\hline TF-ECC-BLA & $\begin{array}{l}\text { In Iline from blowdown loop acc injection } \\
\text { accumulator }\end{array}$ & & & \\
\hline TF-BCC-OLA & $\begin{array}{l}\text { In line from operating loop ECC infection } \\
\text { accumulator }\end{array}$ & & & . \\
\hline METAL TEMPERATURE & & & & $\begin{array}{l}\text { Chrome1-Alume1 therrocouplea; estimated } \\
\text { accuracy to w1thin } \pm 7 \cdot \mathrm{F}\end{array}$ \\
\hline$\underline{\text { Core Barrel }}$ & & $33-650^{\circ} \mathrm{P}$ & 13 & $\begin{array}{l}\text { The thermocouples located in the core barrel } \\
\text { vere partially exposed to the local fluid } \\
\text { and, therefore, may have been ollighty } \\
\text { 1nfluenced by temperature of the fluld. }\end{array}$ \\
\hline$T H-47 C-0$ & 247 1nches, $0^{\circ}, 1 / 8$ inch from $O D$ & & & Data acquisition aystem for $T M-47 C-0$ falled \\
\hline$T M-47 C-180$ & 247 inches, $180^{\circ}, 1 / 8$ inch from on & & & \\
\hline$T M-62 C-45$ & w62 inches, $45^{\circ}, 1 / 8$ inch from od & & & \\
\hline$T H-77 C-0$ & 9.77 tnches, $0^{\circ}, 1 / 8$ Inch from uv & & & \\
\hline$T M-77 \mathrm{C}-180$ & a77 inches, $180^{\circ}, 1 / 8$ inch from $O D$ & & & \\
\hline$T M-94 C-45$ & 295 inches, $45^{\circ}, 1 / 8$ inch from od & & & \\
\hline$m i-94 C-16-45$ & as inches, $45^{\circ}, 1 / 16$ inch from 10 & & & \\
\hline Vegse1 Na11 & & $33-650^{\circ} \mathrm{F}$ & 14 & \\
\hline$T M-67 V=49$ & 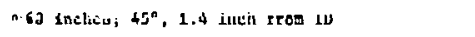 & & & \\
\hline$T M-63 V-225$ & ح63 inches, $225^{\circ}, 1 / 4$ inch from ID & & & \\
\hline TM-78V-0 & $\sim 78$ inches, $0^{\circ}, 1 / 4$ inch from ID & & • & \\
\hline $\mathrm{TN}-78 \mathrm{~V}-90$ & 278 Inches, $90^{\circ} 1 / 4$ tnch from ID & & & $\begin{array}{l}\text { Data acquisition system for TH-78V-180 } \\
\text { Ea1led. }\end{array}$ \\
\hline$T M-78 V-180$ & 278 inches, $180^{\circ}, 1 / 4$ 1nch from oD & & & \\
\hline
\end{tabular}


TABLE IV (contd.)

DATA PRESENTATION FOR ISOTHERMAL TEST 1009

TABLE IV (contd.)

DATA PRESENTATION FOR ISOTHERMAL TEST . 1009

\begin{tabular}{|c|c|c|c|c|}
\hline Measurement ${ }^{[a]}$ & Location $[\mathrm{b}]$ & Range $|c, d|$ & Figure & Coment $^{[d]}$ \\
\hline TM-95V-45 & 295 taches $45^{\circ} 1 / 2$ inch from oD & & & \\
\hline TM-95V-225 & 295 Inches, $225^{\circ}, 1 / 4$ Inch from ID & & & \\
\hline TM-95V-25-45 & 295 inches, $45^{\circ}, 1 / 4$ inch from id & & & \\
\hline $\mathrm{T} 1-116 \mathrm{~V}-0$ & 2116 1nches, $0^{\circ}, 1 / 4$ lạch from id & & & \\
\hline$T M-116 \mathrm{~V}-180$ & N 118 inches, $180^{n}, 1 / 4 \cdot$ lucli from in & & & \\
\hline Lower Plenum Vessel Wall & & $33-650^{\circ} \mathrm{F}$ & 15 & \\
\hline TM-LH-276 & In luwet plenum head & & & \\
\hline$T M-L P-I D L$ & $\begin{array}{l}4.9 \text { 1nches buluw luwe plenum upper Crayloc } \\
\text { t1ange face, } 270^{\circ} \text { from cold leg centerilne, } \\
1 / 16 \text { inch from io of filler piece. }\end{array}$ & & & \\
\hline TM-LP-IDU & $\begin{array}{l}5.0 \text { Inches above lower plenum upper Grayloc } \\
\text { fiange face, } 270^{\circ} \text { from cold leg centerifine, } \\
1 / 16 \text { inch from in of flller piece }\end{array}$ & & & \\
\hline TM-LPP-VOD & 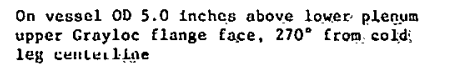 & & & \\
\hline Optraties loop & & $33-650^{\circ} \mathrm{F}$ & & \\
\hline TM-1B & 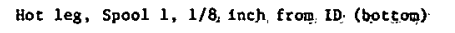 & & 16. & No calibration step ava1lable for $104-18$ \\
\hline TM-1I & Hot leg, Spool 1, 1/8 inch from. ID (top): & & 16 & \\
\hline$T M-198$ & Cold 1eg, Spool 19, 1/8: tach from (bottom) & & 17 & \\
\hline TM-19H & Cold leg, Spool 19, 1i/8, inch froos. ID (alddle) & & 1.7 & \\
\hline$T M-19 \mathrm{I}$ & Cold leg, Spooll 19, t/8 then fD (top) & & 17 & \\
\hline$T r-19 S$ & Cold leg, Spool 19, outsside surface (top). & & n7 & \\
\hline $\mathrm{m}-22 \mathrm{~B}$ & Cold leg, Spool 22, 1/8 1nch, from, ID (bot topm) & & 18 & \\
\hline $\mathrm{N}-22 \mathrm{H}$ & Cold: leg, Sppol 22, 1/8 1nch from..ID (mlddle) & & 18 & \\
\hline TH-22I & Cold leg, Spool 22, 1/8inch from ID (top) & & 18 & \\
\hline Ty-22s & Cold leg, Spoo1 22, Outga1de surfaçe (top) & & 18 & \\
\hline Bloudiown Loop & & $33-650^{\circ} \mathrm{F}$ & & : \\
\hline $\mathrm{TM}-96$ & $\begin{array}{l}\text { Simulated pump suction, Spool } 96,1 / 16,1 \mathrm{pch} \text {. } \\
\text { from ID }\end{array}$ & . & 19 & \\
\hline MOMENTUM EUTTX & & & & 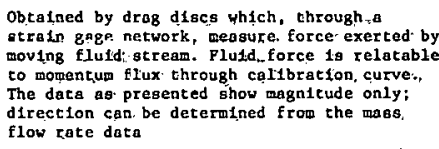 \\
\hline Operat1ng loop & & $\frac{+100 t \operatorname{to} \pm 2.00 \times 10^{4}}{16 / f t-\sec ^{2}}$ & & $\mu^{2}$ \\
\hline FD-1 & Hot leg, Spool 1 & & 20 & \\
\hline Fo-5 & Hot $1 \mathrm{eg}$, Spool 5 & & 20. & \\
\hline FD-15 & Pump suction, Spool 15 & & 21 & \\
\hline FD-19. & Pump discharge, spool 19 & & 21. & \\
\hline FD-22 & Cold lee, Spool 22 & & 21 & \\
\hline Blowdown Loop. & & & 22 & \\
\hline FD-50 & Cold leg, Spool so & $\frac{+430 \text { to } \pm 5.0 \times 10^{4}}{1 b / f t-\sec ^{2}}$ & & \\
\hline FD-70 & Hot leg, Spool 70 & $\frac{ \pm 500 \mathrm{co} \cdot \pm 6.0 \times 10^{4}}{1 b / f t-\sec ^{2}}$ & & \\
\hline FD-76 & Cold 1eg, Spool 76 & $\frac{ \pm 500 \text { to }+6.0 \times 10^{4}}{1 b / f t-\sec ^{2}}$ & & \\
\hline \multicolumn{5}{|l|}{ Pressure Suppresstion_Svstex } \\
\hline $\mathrm{FD}-83$ & Header near downcomer & & & Not reported; system was noc callbrated. \\
\hline \multicolumn{5}{|l|}{ Core Barral Inloc } \\
\hline FD-224 & 110 inches, $315^{\circ}$ (target centered in gap) & 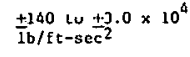 & 23 & . \\
\hline VOLUMETRIC FLOW RATE & & & & Obtained by turbine flowmeters \\
\hline Operaring Loop & & \pm 40 to $\pm 800 \mathrm{gpa}$ & 24 & \\
\hline FT-1 & Hot 1eg, Spool 1 & & & \\
\hline FT-19 & Pump discharge, Spool 19 & & & \\
\hline ET-22 & Cold leg, Spool 22 & & & \\
\hline Blowdown Loop & & & & \\
\hline $\mathrm{FT}-70$ & Hot le8, Spool 70 & \pm 20 to $\pm 500 \mathrm{gpm}$ & 25 & \\
\hline Core Barrei Inlet & & & & \\
\hline FT-C-1 & 110 1nches from upper vessel flunge face & \pm 40 to $\pm 300 \mathrm{gpm}$ & 26 & $\begin{array}{l}\text { PT-C-1 electronic saturation occurs for } \\
\text { flows greater than } 350 \mathrm{gpm}\end{array}$ \\
\hline \multicolumn{5}{|l|}{ Presgurtzer } \\
\hline $\mathrm{FT}-41$ & Outlet, Spool 41 & \pm 8 to $\pm 200 \mathrm{gpm}$ & 27 & \\
\hline BCC System & & & 28 & . \\
\hline FT-ECC-OLA & $\begin{array}{l}\text { In ECC line from operating loop ECC injection } \\
\text { accumulator }\end{array}$ & \pm 4.0 co $\pm 50 \mathrm{gpm}$ & - & $\begin{array}{l}\text { For FT-ECC-OLA, at about } 54 \text { sec ECC water } \\
\text { flow ends. N1trogen gas used as a pres- } \\
\text { surizer continues to flow }\end{array}$ \\
\hline PT-ECC-BLA & $\begin{array}{l}\text { In ECC line from blowdown loop ECC infection } \\
\text { accumulator }\end{array}$ & \pm 2.5 to $\pm 20 \mathrm{gpD}$ & & $\begin{array}{l}\text { For FT-ECC-BLA, at about } 52 \mathrm{sec} \text { ECC water } \\
\text { flow ends. Nitrogen gas used as a pres- } \\
\text { surizer continues to flow }\end{array}$ \\
\hline
\end{tabular}




\section{TABLE IV (contd.)}

DATA PRESENTATION FOR ISOTHERMAL TEST 1009

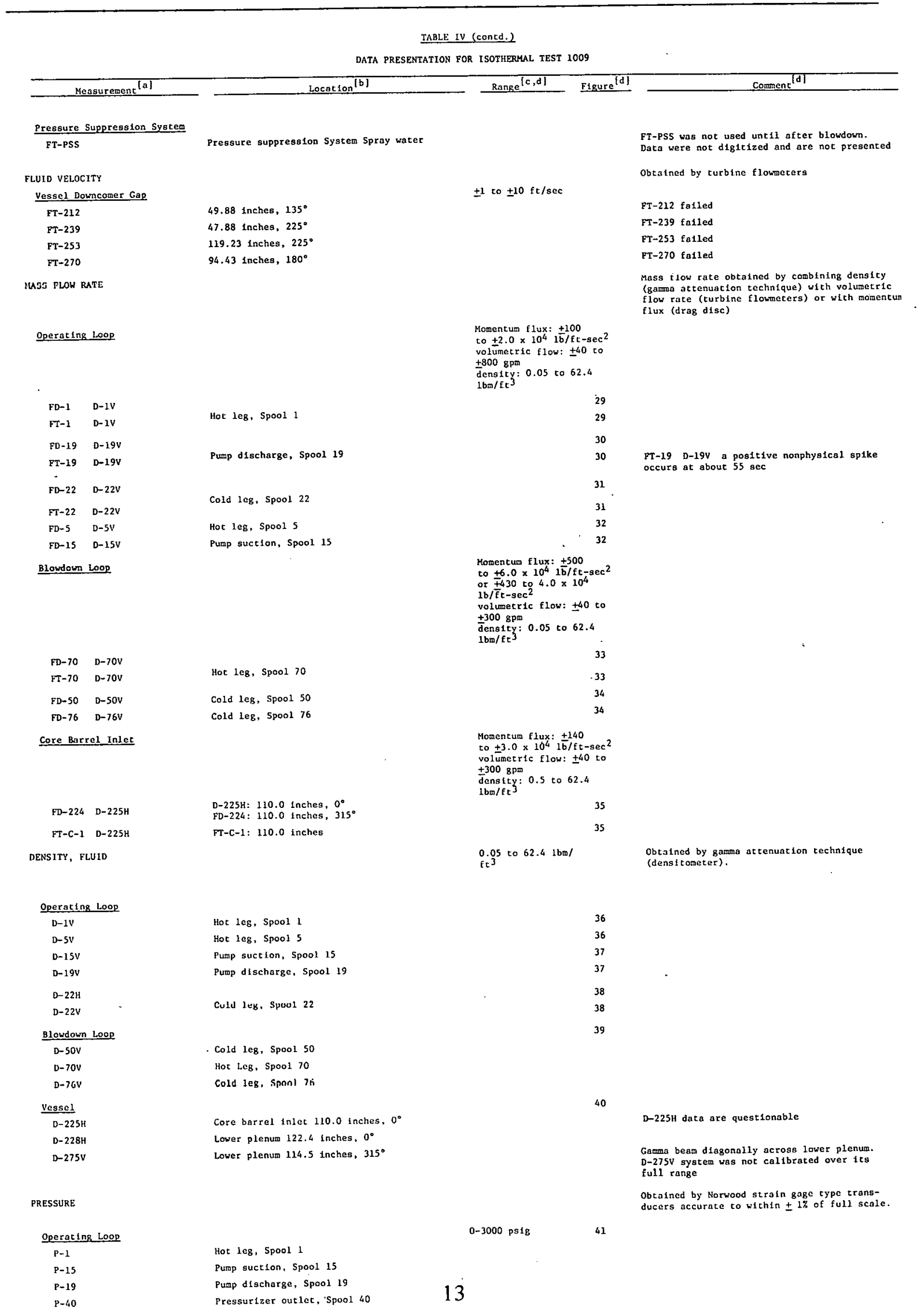


TABLE IV (contd.)

DATA PRESENTATION FOR ISOTHERMAL TEST 1009

TABLE IV (contd.)

DATA PRESENTATION FOR ISOTHERMAL TEST 1009

\begin{tabular}{l}
\hline Measurement $[$ [a] \\
\hline$\frac{\text { Blowdown Loop }}{\text { P.6-HN2 }}$ \\
P-50 \\
P-51 \\
P-61 \\
P-62 \\
P-70 \\
P-76 \\
Vesse1 \\
P-207 \\
P-255
\end{tabular}

Pressure Suppression System

$0-3000$ parg

$43^{\prime \prime}$

Simulated pump side, nozzle throat,

Cold $1 \mathrm{eg}$, Spool 50

Cold leg, domstrcas of vessel-sida

nozale, Station 51

Downstrean of hot les nozzle, Station 61

Pump side, rupture assembly inner disc

Hot 1 eg, Spool 70

Cold leg. Spool 76

Out let plenum, 28.4 Inches, $30^{\circ}$
Lower plenum, 121.3 inches, $240^{\circ}$

Range Figure $^{[c]}$

42

$0-3000$ psig

Comment $^{[0]}$

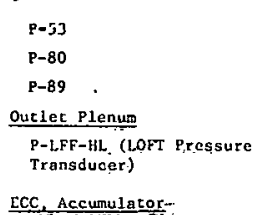

ECC. Accumulator

P-ECC-BLA

P-ECCC-OZA

different Iạl PREsSURe
Blowdom loop cold log, spost $53 \quad 0-1000$ psig

Pressure suppresglon beader between elbows 0-200 pats vapor chamber; of pressure suppression vessel- 0-200 psis,

Hot 1 eg stub in outiet plenum

$0-3000$ psig

B10wdown Loop ECC accumularor Operating Loop ECC accumulator
The pressure suppression tank and header were venced tn' armnspherfir pressure until. 2 sec
prfor to blowdown. The: 27 psig indicated at blowdown by the cransducers in the pregsure suppression system is not understood. No detectable, zero shift or gafn error could be identif ied" nor could any' physical explanation be given for this. diacrepancy- A regulated. pressure steam lnjeerion control system was pressibn: aystemecto to the pressure supsure history.during blowdow. The'pressurecontrol, system fatled and manusl override at tempte: resulted in the fluctuations in" the pressurea suppression system pressure dürsng. bloudown.

No calibration. step avallable for $P=53$
45

46.

Obtalned by differentali pressure transduccrs accurate to whthin \pm 1 of of full ranget: systera conditions. Inttial condit1ong-shown In the data are the result of flow-inducet' pressura'gradients and.density changes. from ambient ton operating condtitions:

DP-22-1 falled

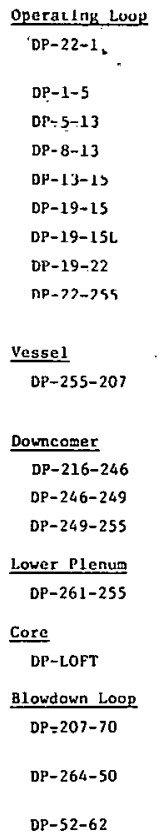
Across pressure vessel, operating loop
cold leg to hot leg, Spool 22 to Spool 1 Hor leg, Spool 1 to Spool 5

\pm 0.72 psid

Hoc les, spool 1 co 5 ool 5 to 5 pool $13 \quad+28.9$ psid Pump suction orifice, Spool. 8 to Spool $13 \quad \pm 10.8$ psid Spool 13 lu Spuol 1s

Across pump, Spool 19 to Spool 15

Across pump. Spool 19 to Spool is

Spool 19 to Spool 22

Cold leg to lower plenum, Spool 22 to

+50.0 psid

$\pm 3.6 \mathrm{psid}$

\pm 10.8 psid

$+10.8 \mathrm{psid}$

Vessel lower plenum to vessot
Scation 255 to Stacion 207

\pm 18.0 psid

Station 216 to Station 246 ,

Station 246 to Station 249

Station 249 to Station 255

\pm 1.8 psid
+1.8 psid

$\pm 0.72 \mathrm{psid}$

$\pm 0.72$

$\pm 50.0$

\pm 3.6 psid

\pm 18.0 psid

leg. Station 207 to Spool 70

vessel inlet annulus to blowdown loop cold leg. Station 264 to Spool 50

deross rupture discs, Spool 52 to Spool $62 \quad \pm 500.0$ psid

47
48
49
50
51
52
53
54
55
56
57
58
59
60
61
62
63

47.

48

50.

51

52

54.

ss

56

60

62

63 
TABLE IV (contd.)

DATA PRESENTATION FOR ISOTHERMAL TEST 1009

IABLE IV (contd.)

DATA PRESENTATION FOR ISOTHERMAL TEST 1009

\begin{tabular}{|c|c|c|c|c|}
\hline Measurement ${ }^{[\mathrm{a}]}$ & Location $[\mathrm{b}]$ & Range $^{[e, d]}$ & Figure $^{[\mathrm{d}]}$ & Comment $^{[\mathrm{d}]}$ \\
\hline DP-76-61 & Across hot leg nozzle, Spool 76 to Station $61 \pm$ & \pm 1000.0 psid & 64 & \\
\hline $\mathrm{DP}-76-\mathrm{HN} 2$ & $\begin{array}{l}\text { Spool } 76 \text { to hot leg nozzle downstream throat } \pm \\
\text { (Port 2) }\end{array}$ & $\pm 500.0 \mathrm{psid}$ & 65 & \\
\hline DP- $96-76$ & Across simulated pump, Spool 96 to Spool $76 \pm$ & $\pm 100.0 \mathrm{psid}$ & & \\
\hline DP $-70-96$ & $\begin{array}{l}\text { Across simulated steam generator, Spool } 70 \\
\text { to Spool } 96\end{array}$ & \pm 100.0 psid & 67 & \\
\hline DP5-HN2-HN4 & $\begin{array}{l}\text { Vessel side, downstream nozzle throat (Port 2) } \\
\text { to downstream nozzle expansion section (Port 4) }\end{array}$ & \pm 1000.0 psid & 68 & $\begin{array}{l}\text { DP5-HN2-HN4 the cause of the magnitude } \\
\text { difference between Test } 1009 \text { and other } \\
\text { isothermal tests is not understood. A } \\
\text { gain error during Test } 1009 \text { was suspected, } \\
\text { but no gain error could be identified }\end{array}$ \\
\hline DP6-HN2-HN4 & $\begin{array}{l}\text { Simulated pump side, downstram nozzlo throat } \\
\text { (Port 2) to downstream nozzle expansion } \\
\text { section (Port } 4 \text { ) }\end{array}$ & 11000.0 pside & 69 & \\
\hline $\mathrm{DP}-\mathrm{HN} 4-61$ & $\begin{array}{l}\text { Across hot leg nozzle outlet, downstream } \\
\text { nozle expansion section (Port 4) to } \\
\text { Station } 61\end{array}$ & \pm 18.0 psid & 70 & \\
\hline \multicolumn{5}{|l|}{ Pressure Suppression System } \\
\hline DP-207-89 & $\begin{array}{l}\text { Vessel upper plenum to vapor chamber of } \\
\text { pressure suppression tank }\end{array}$ & \pm 500.0 psid & 71 & $\begin{array}{l}\text { For DP-207-89, electronic saturation occurs } \\
\text { for about the first } 17 \mathrm{sec}\end{array}$ \\
\hline DP-81-89 & Header to tank vapor chamber & $\pm 50.0 \mathrm{psid}$ & 72 & \\
\hline DP- $81-85$ & Header to downcomer exit & $\pm 10.8 \mathrm{psid}$ & 73 & \\
\hline LIQUUID LEVEL & & & & $\begin{array}{l}\text { Liquid leve } 1 \text { in lower plenum is indicated } \\
\text { by density measurements } \mathrm{D}-228 \mathrm{~B} \text { and } \mathrm{D}-275 \mathrm{~V} \\
\text { and by differential pressure measurement } \\
\text { DP-261-255 }\end{array}$ \\
\hline Lower Plenum & Port 259 & & & System not calibrated, data not digitized. \\
\hline $\begin{array}{l}\text { LL-LFTA-259 } \\
\text { LL-LFTD-259 }\end{array}$ & & & & \\
\hline $\begin{array}{l}\text { LL-LFTD- } 259 \\
\text { Pressure Suppression System }\end{array}$ & & & & \\
\hline \multicolumn{5}{|l|}{ Pressure Suppression System } \\
\hline LL-PSS & Suppression tank & 3.64 psid & 74 & $\begin{array}{l}\text { Obtained by differential pressure cell having } \\
\text { one leg connected to a standpipe and the } \\
\text { other leg attached to a port in the bottom } \\
\text { of the pressure suppression tank }\end{array}$ \\
\hline PUMP CHARACTERISTICS & Operating loop pump & & & \\
\hline$\frac{\text { Pump Speed }}{\text { PS-RPM }}$ & & & & \\
\hline PS-RPM & & 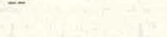 & 75 & \\
\hline$\frac{\text { Pump Power }}{\text { PW-PMP }}$ & & - & 76 & \\
\hline Pump Torque & & & & \\
\hline T-PMP & s & $\cdots$ & 77 & \\
\hline TIME OF BREAK & & & & $\begin{array}{l}\text { Data not presented; measurement established } \\
\text { time of rupture as indicated by } t=0 \text { seconds } \\
\text { on all data plots }\end{array}$ \\
\hline \multicolumn{5}{|l|}{ Blowdown Loop } \\
\hline $\mathrm{BW}-52$ & Cold leg, vessel side & & & \\
\hline $\mathrm{BW}-62$ & Cold leg, simulated pump side & & & \\
\hline \multicolumn{5}{|l|}{ FLOW DIRECTION } \\
\hline$\frac{\text { Downcomer Gap }}{\text { S-271 }}$ & 65.6 inches, $0^{\circ}$, Station 271 & & 78 & S-271 data are questionable \\
\hline DISPLACEMENT & & & & $\begin{array}{l}\text { System not calibrated, data useful only for } \\
\text { relative motion indication. }\end{array}$ \\
\hline Pressure Suppression System & & & 79 & \\
\hline LDT-PSH & Header first elbow (horizontal deflection) & & & \\
\hline LDT-PSV & $\begin{array}{l}\text { Beneath suppression vesse1 (vessel vertical } \\
\text { deflection) }\end{array}$ & & & \\
\hline [a] Measurement nomenclature & is defined in Reference 1 & & & \\
\hline [b] Measurement locations ar & e shown in Figures 1 through 4 & & & \\
\hline [c] The range indicated is $t$ & hat over which the measurement is considered vali & & & \\
\hline $\begin{array}{l}\text { [d] Ranges, figure numbers, } \\
\text { The figure numbers corr }\end{array}$ & $\begin{array}{l}\text { and comments apply to all measurements within a } \\
\text { spond to the data plots presented. }\end{array}$ & category unless it & indicated oth & erwise. \\
\hline
\end{tabular}




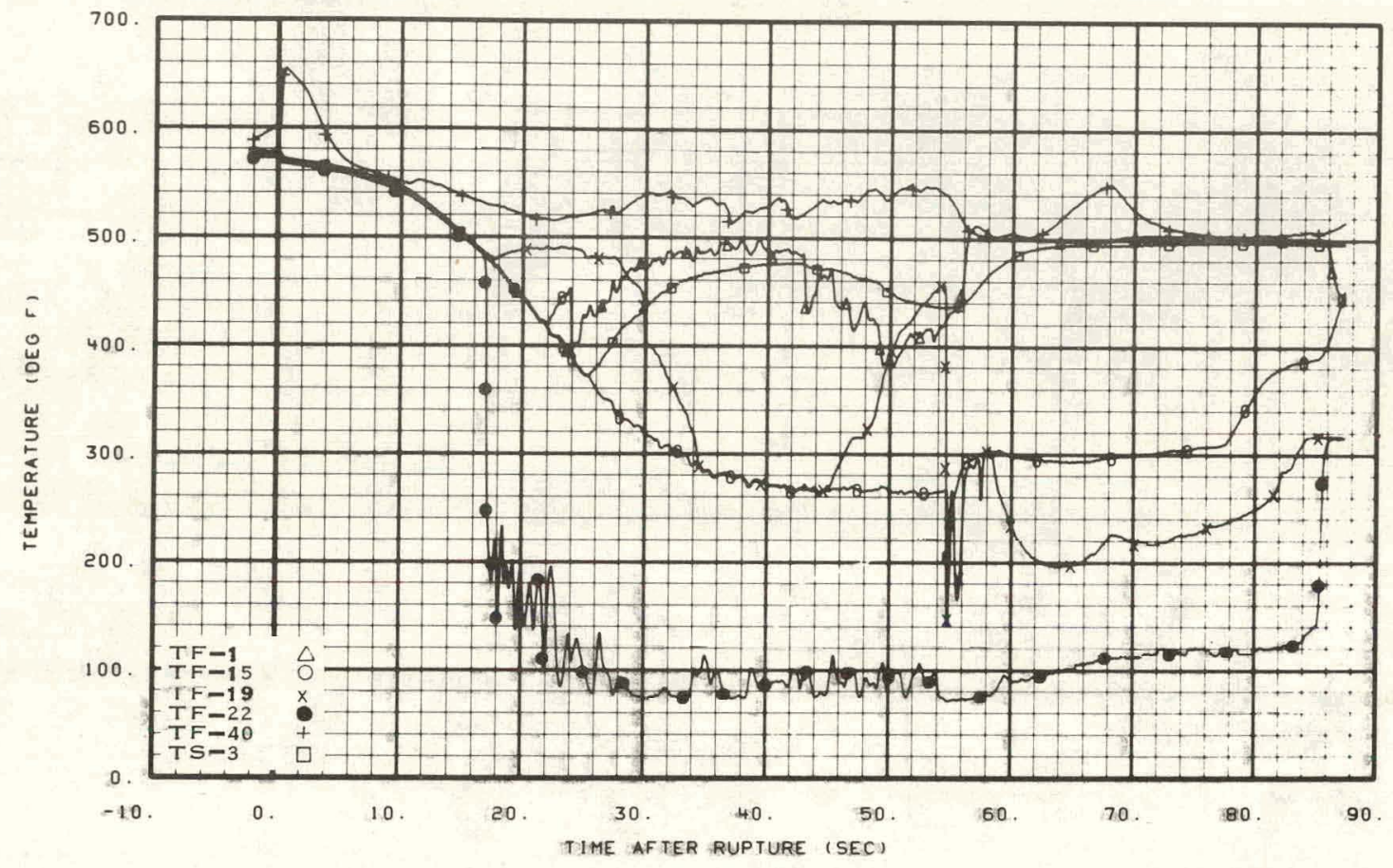

Fig. 5 Fluid temperatures in operating loop.

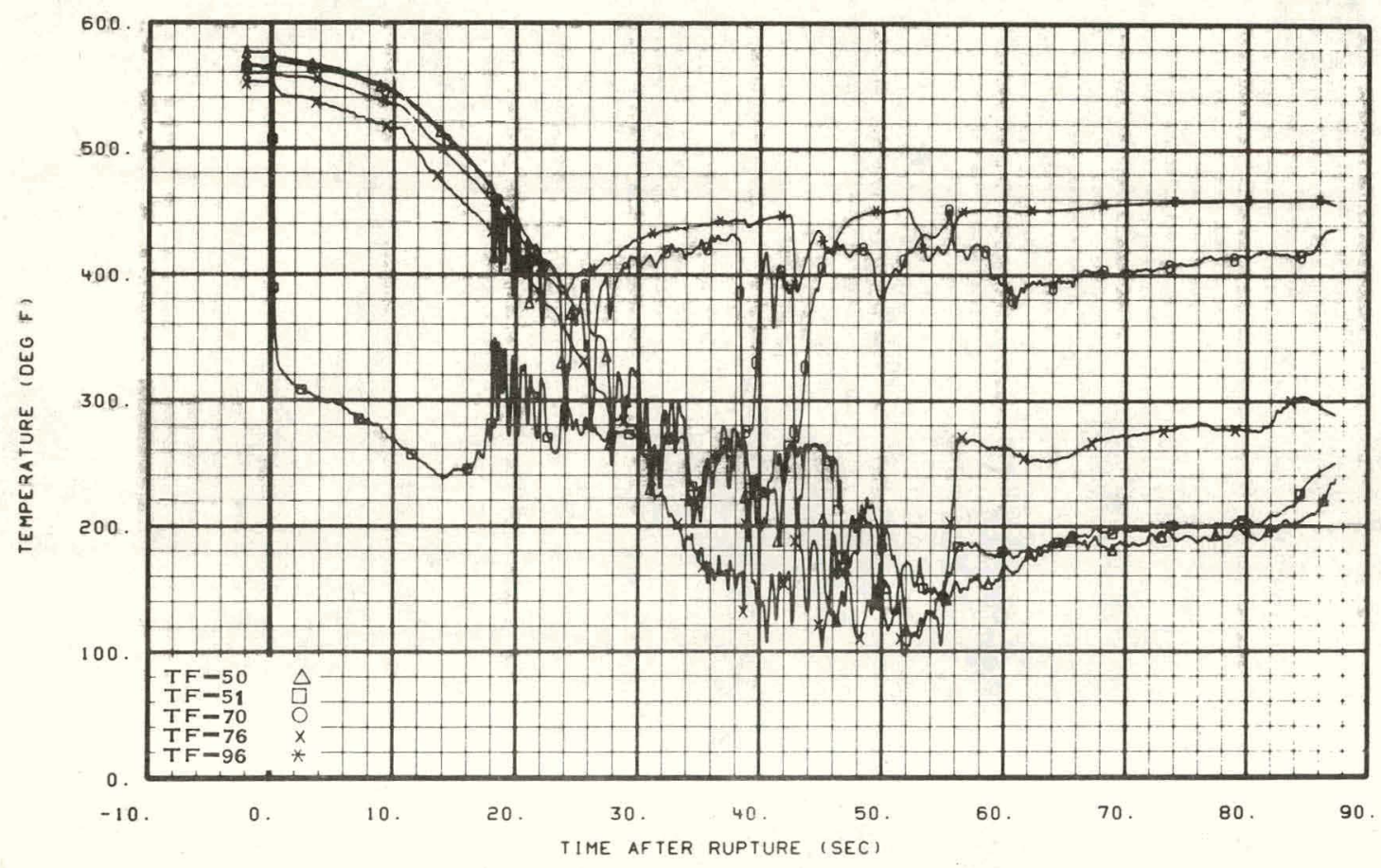

Fig. 6 Fluid temperatures in blowdown 1ocp. 


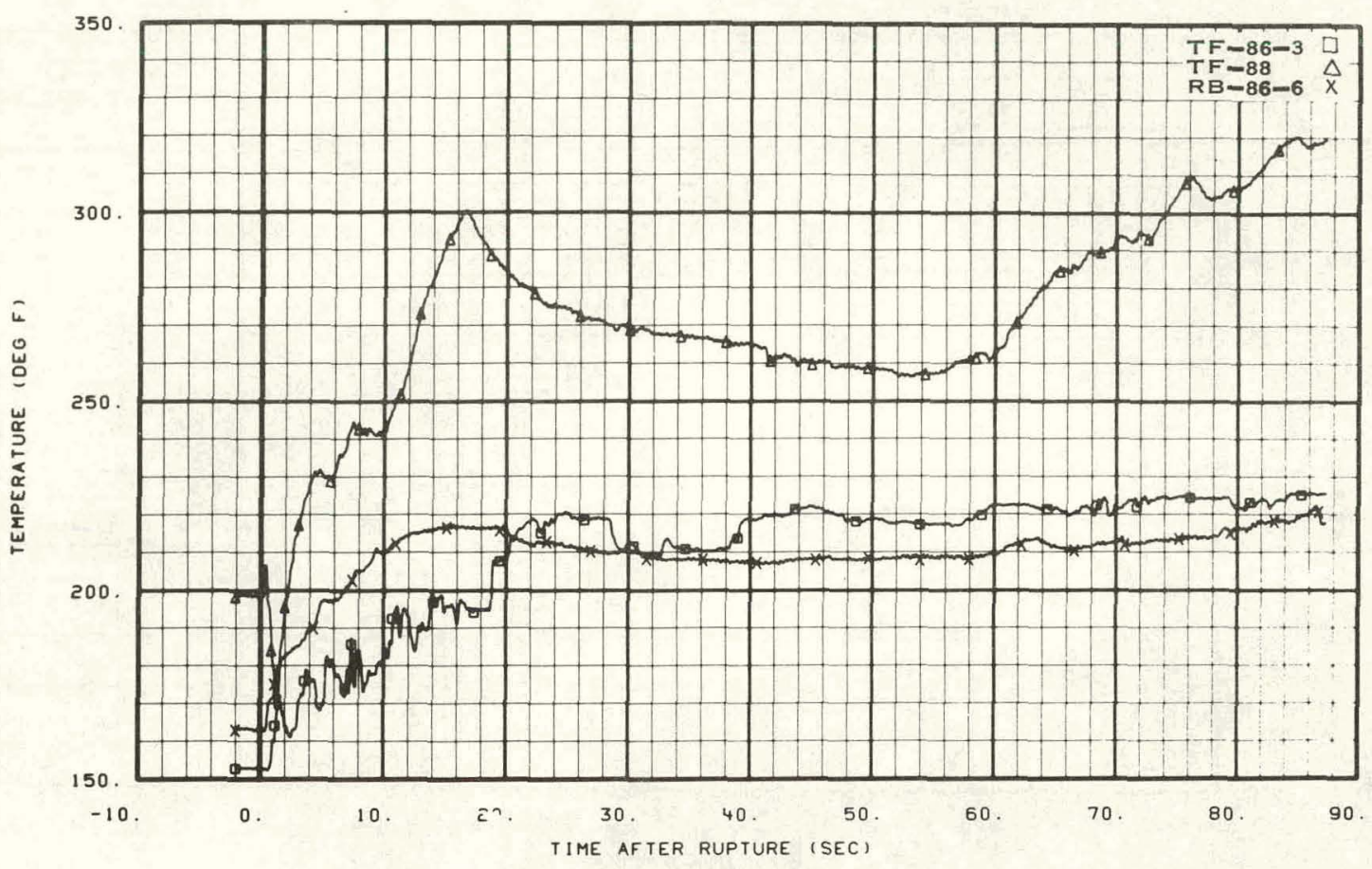

Fig. 7 Fluid temperatures in pressure suppression system.

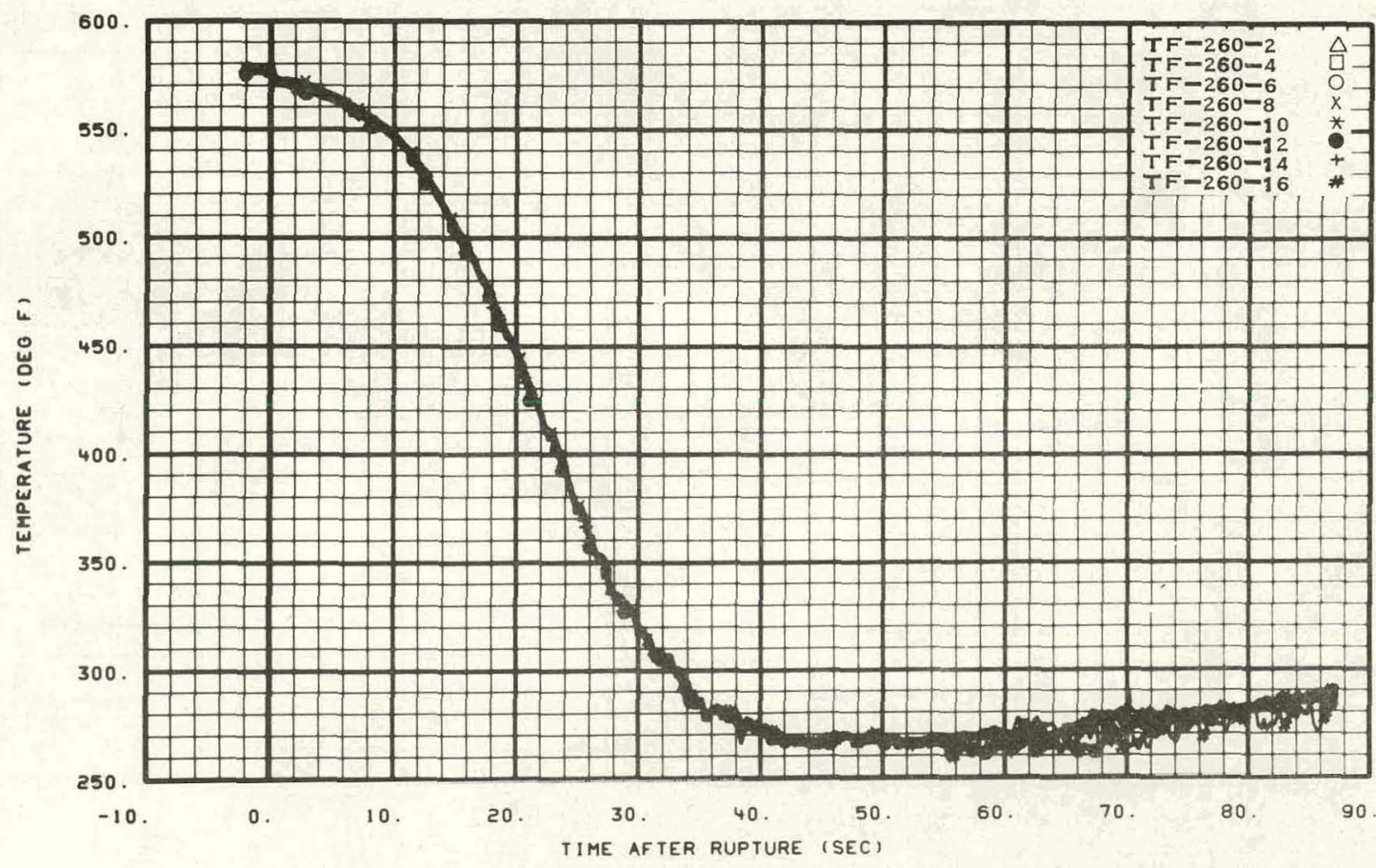

Fig. 8 Fluid temperatures in lower plenum at thermocouple rack. 


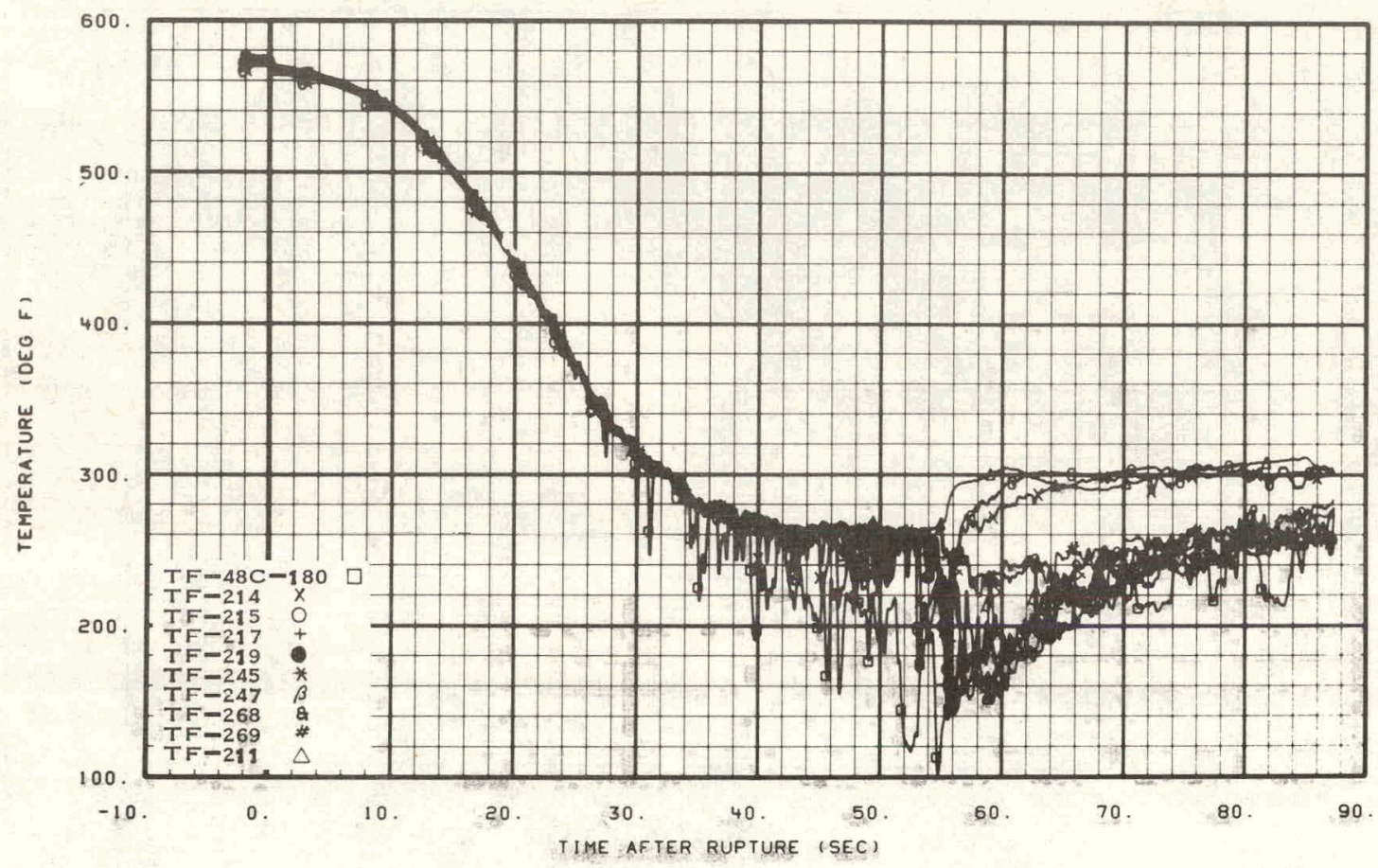

Fig. 9 Fluid temperatures in downcomer gap and outlet plenum.

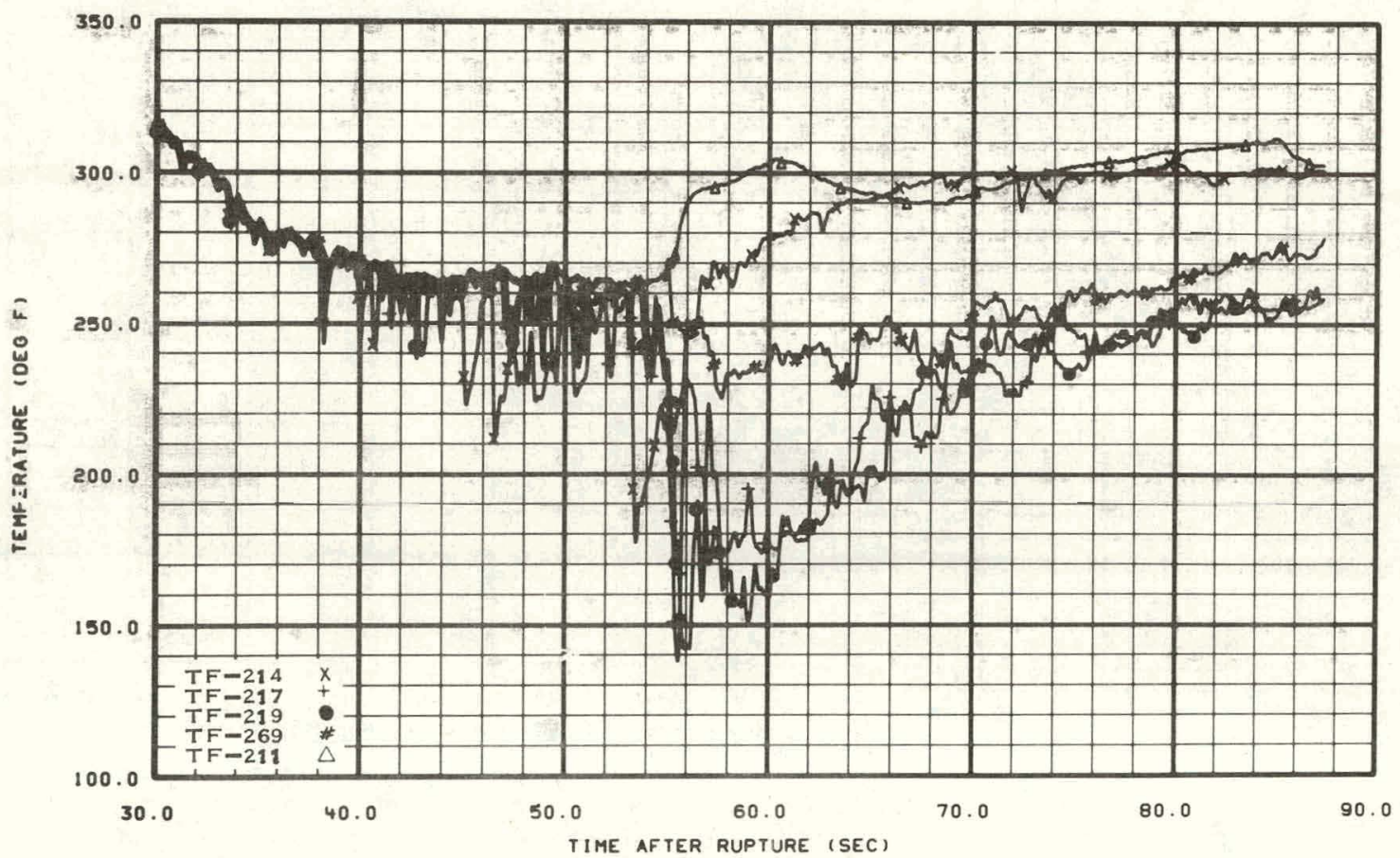

Fig. 10 Fluid temperatures in downcomer gap and outlet plenum (expansion of Figure 9 for $\mathrm{TF}-214, \mathrm{TF}-217, \mathrm{TF}-219, \mathrm{TF}-269$, and $\mathrm{TF}-211$ ). 


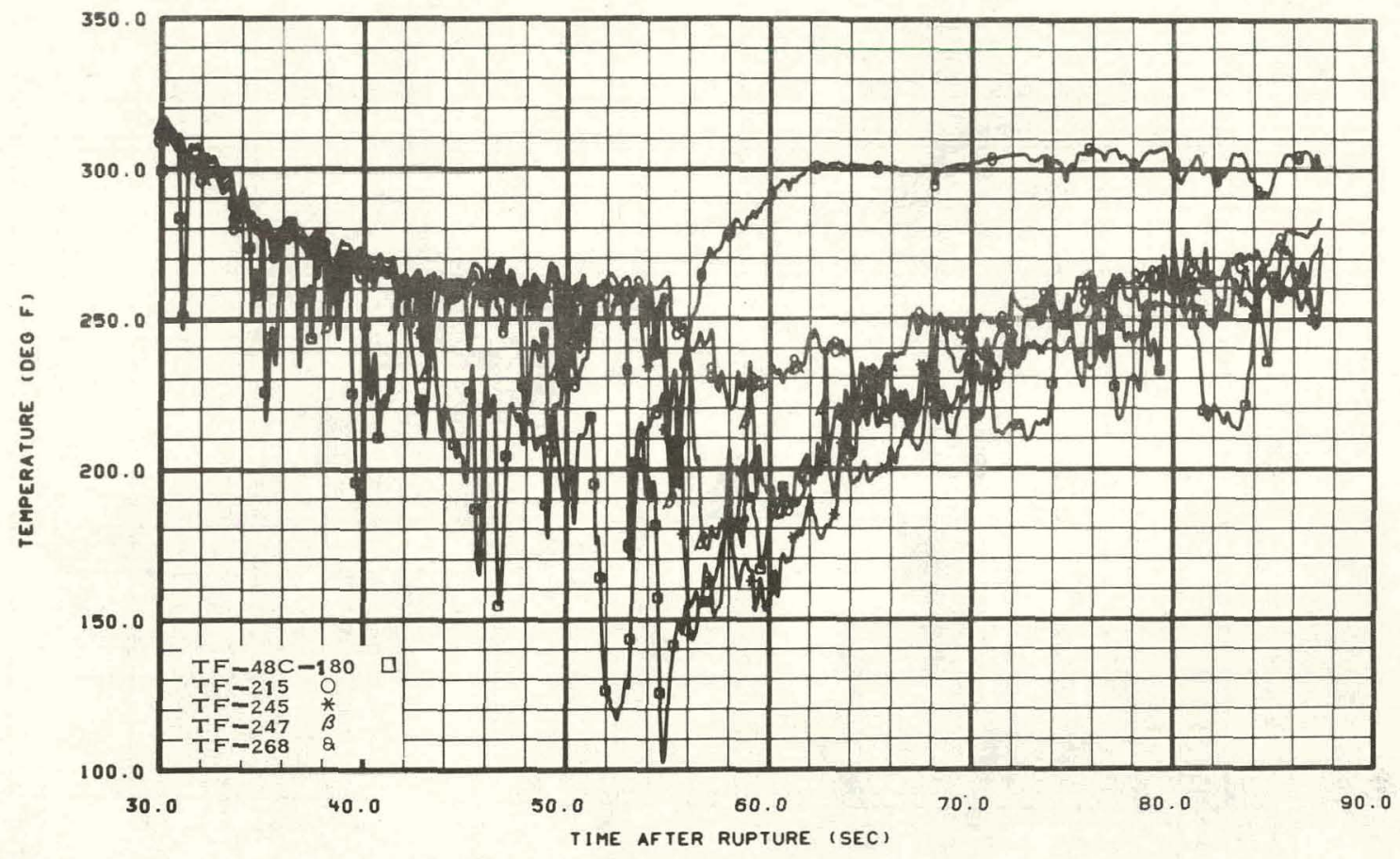

Fig. 11 Fluid temperatures in downcomer gap (expansion of Figure 9 for $\mathrm{TF}-48 \mathrm{C}-180, \mathrm{TF}-215, \mathrm{TF}-245, \mathrm{TF}-247$, and $\mathrm{TF}-268)$.

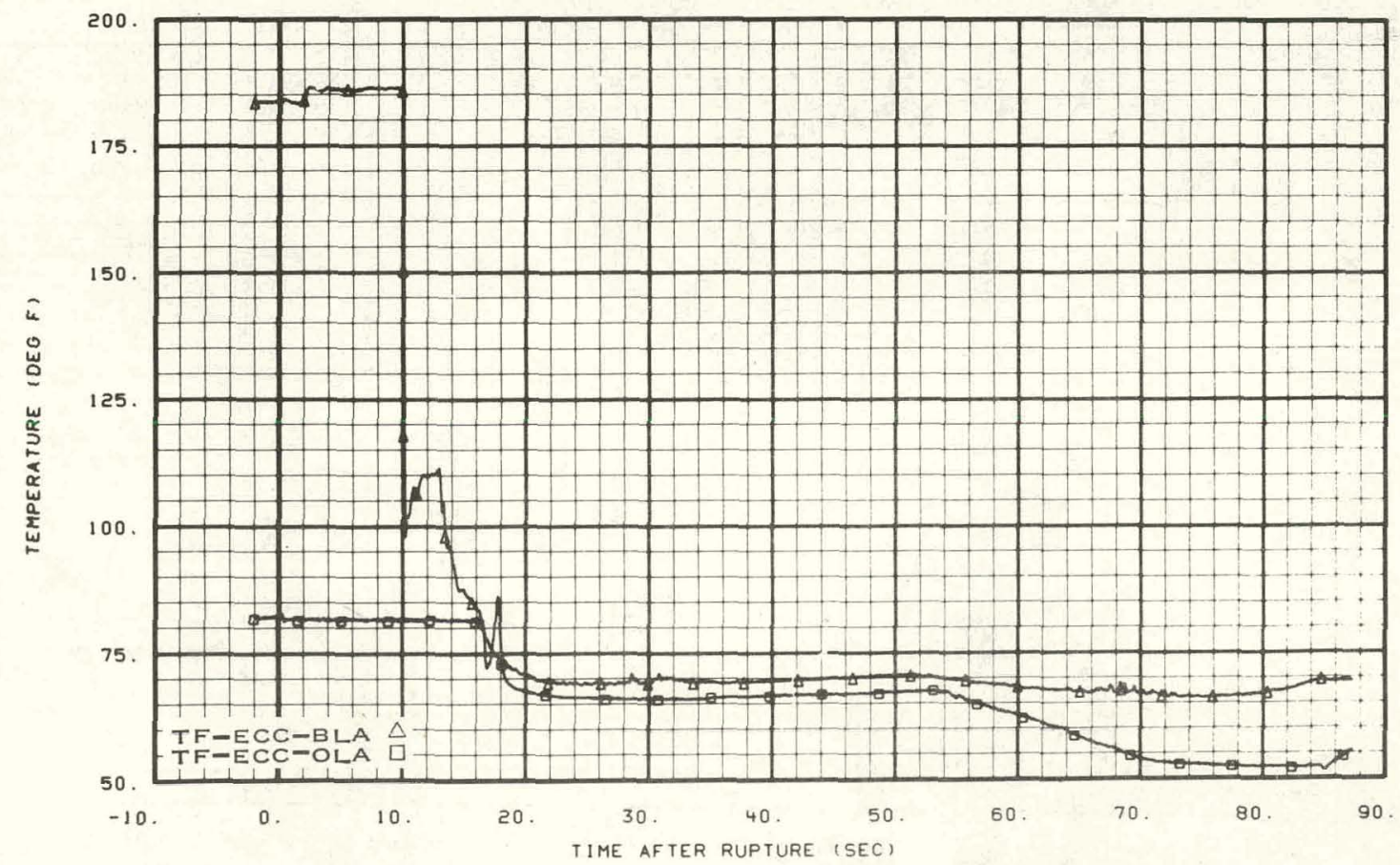

Fig. 12 Fluid temperatures in ECC lines from blowdown loop accumulator tank and operating loop accumulator tank. 


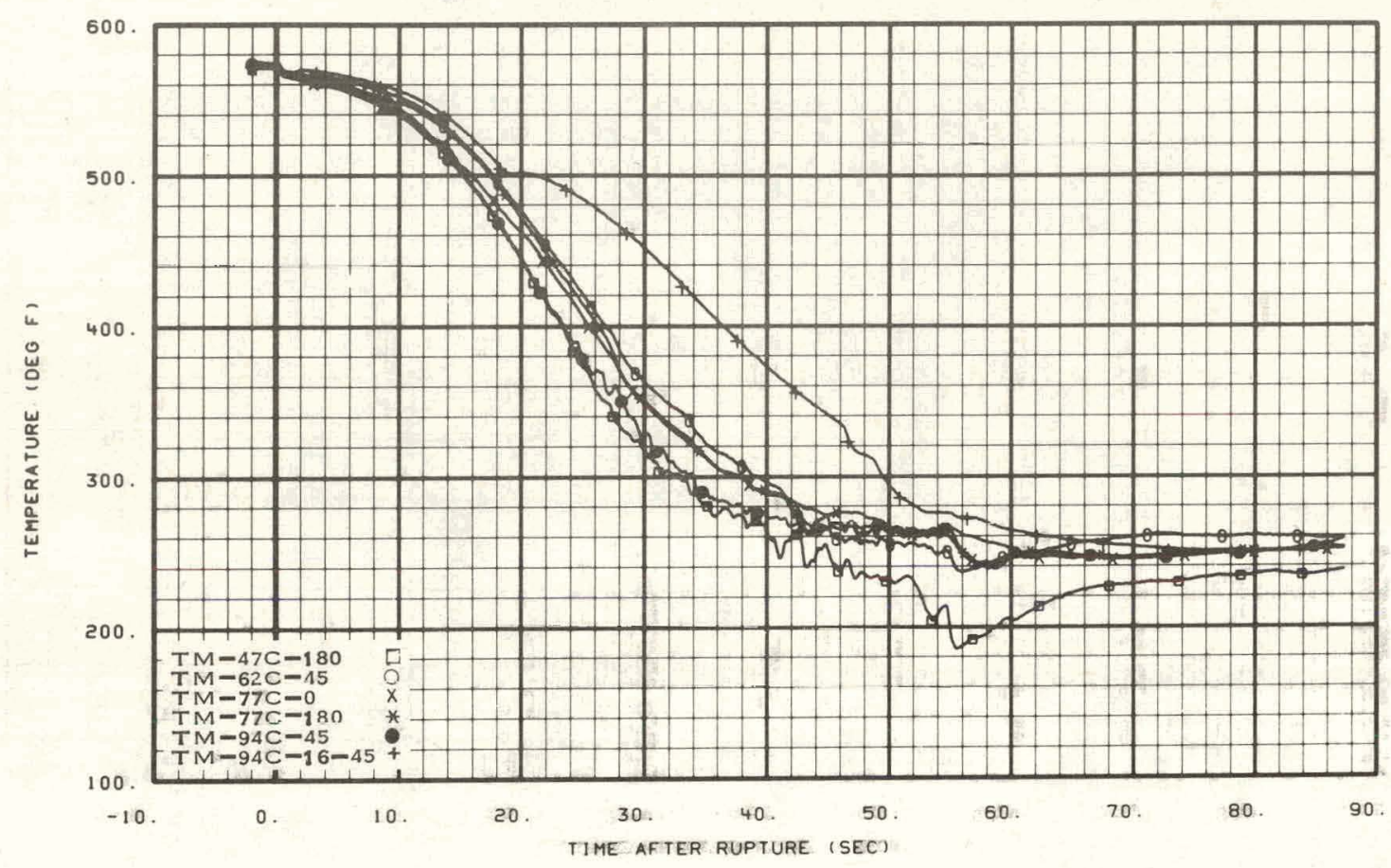

Fig. 13 Metal temperatures in core barrel.

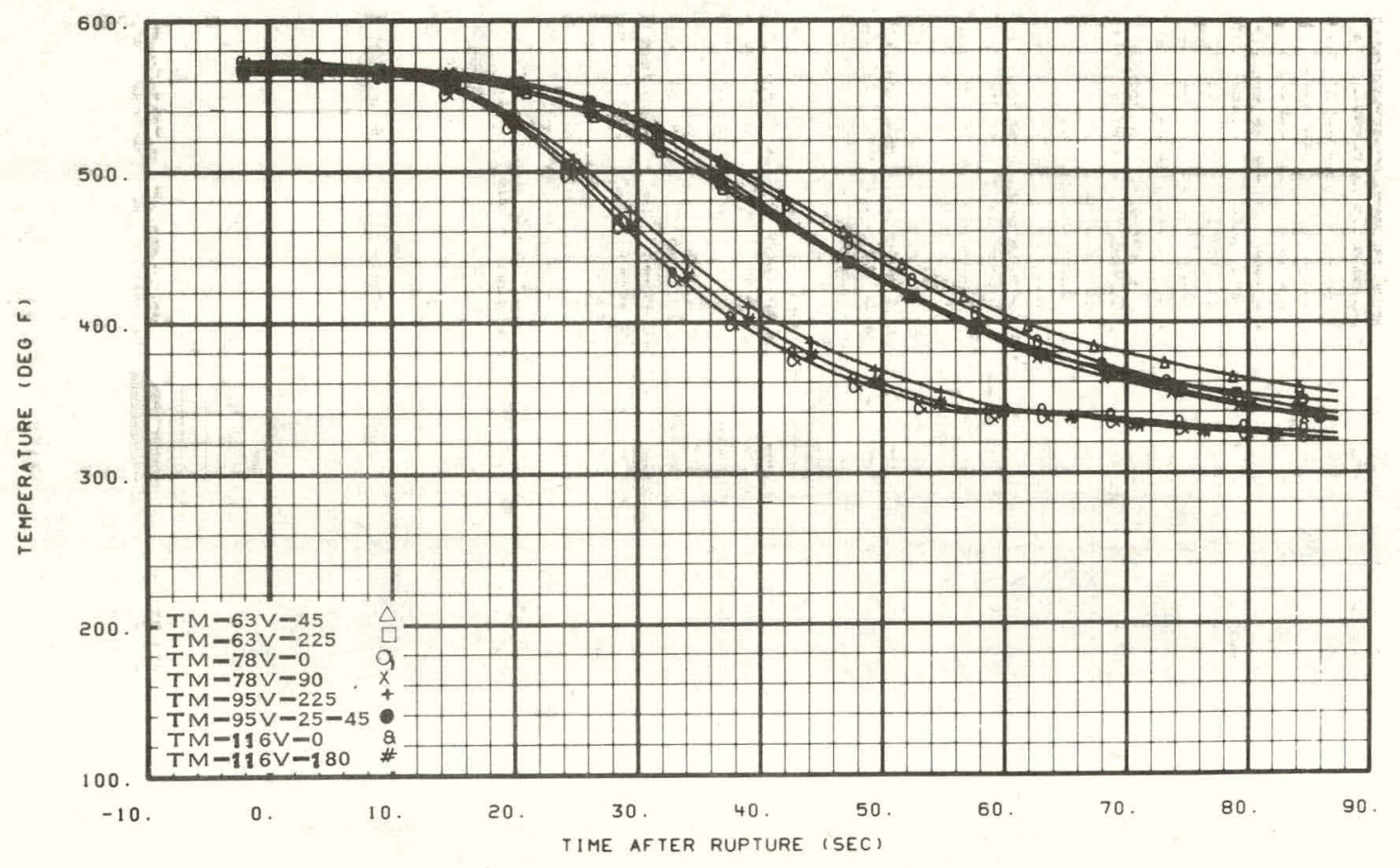

Fig. 14 Metal temperatures in vessel wall. 


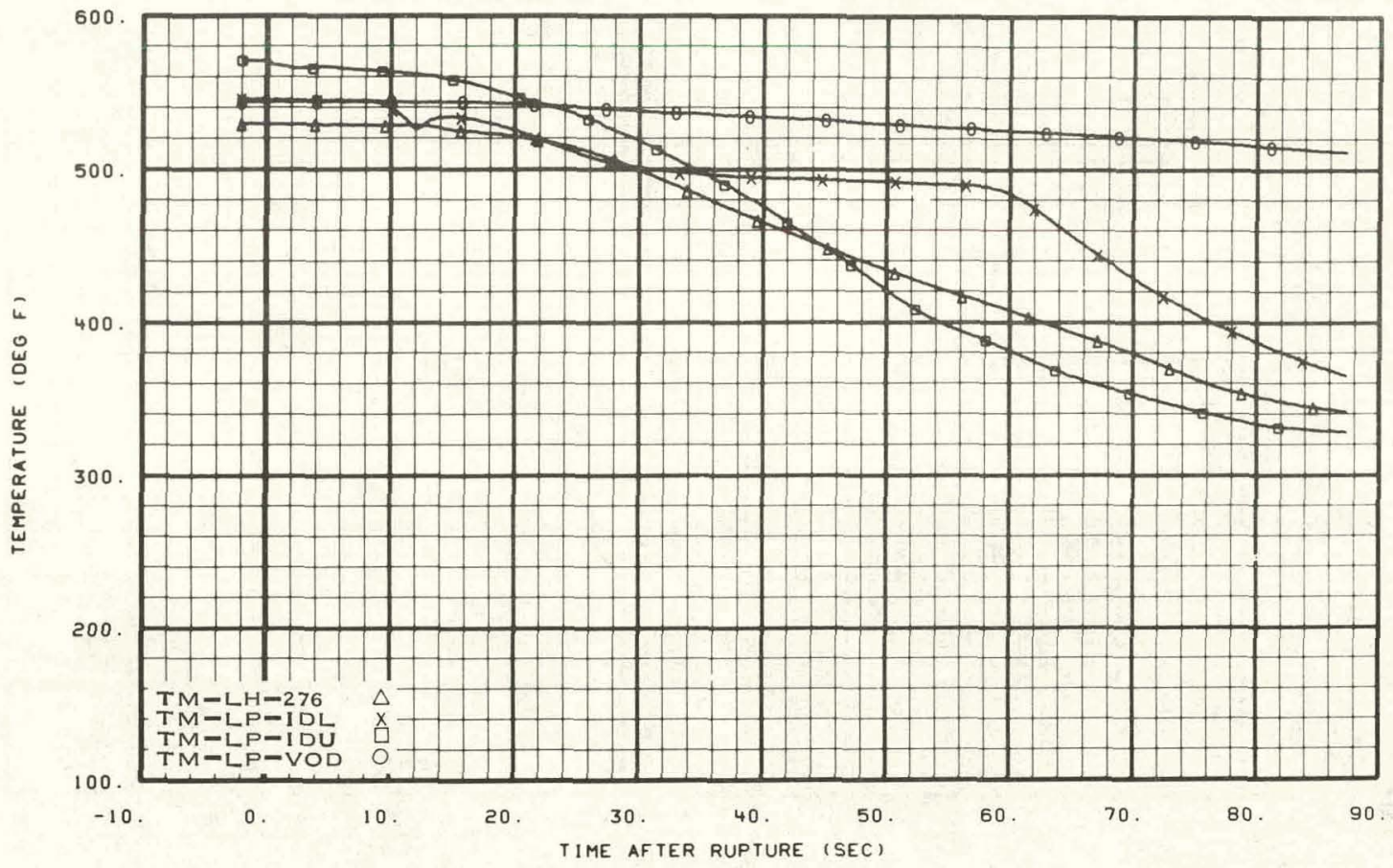

Fig. 15 Metal temperatures in lower plenum vessel wall.

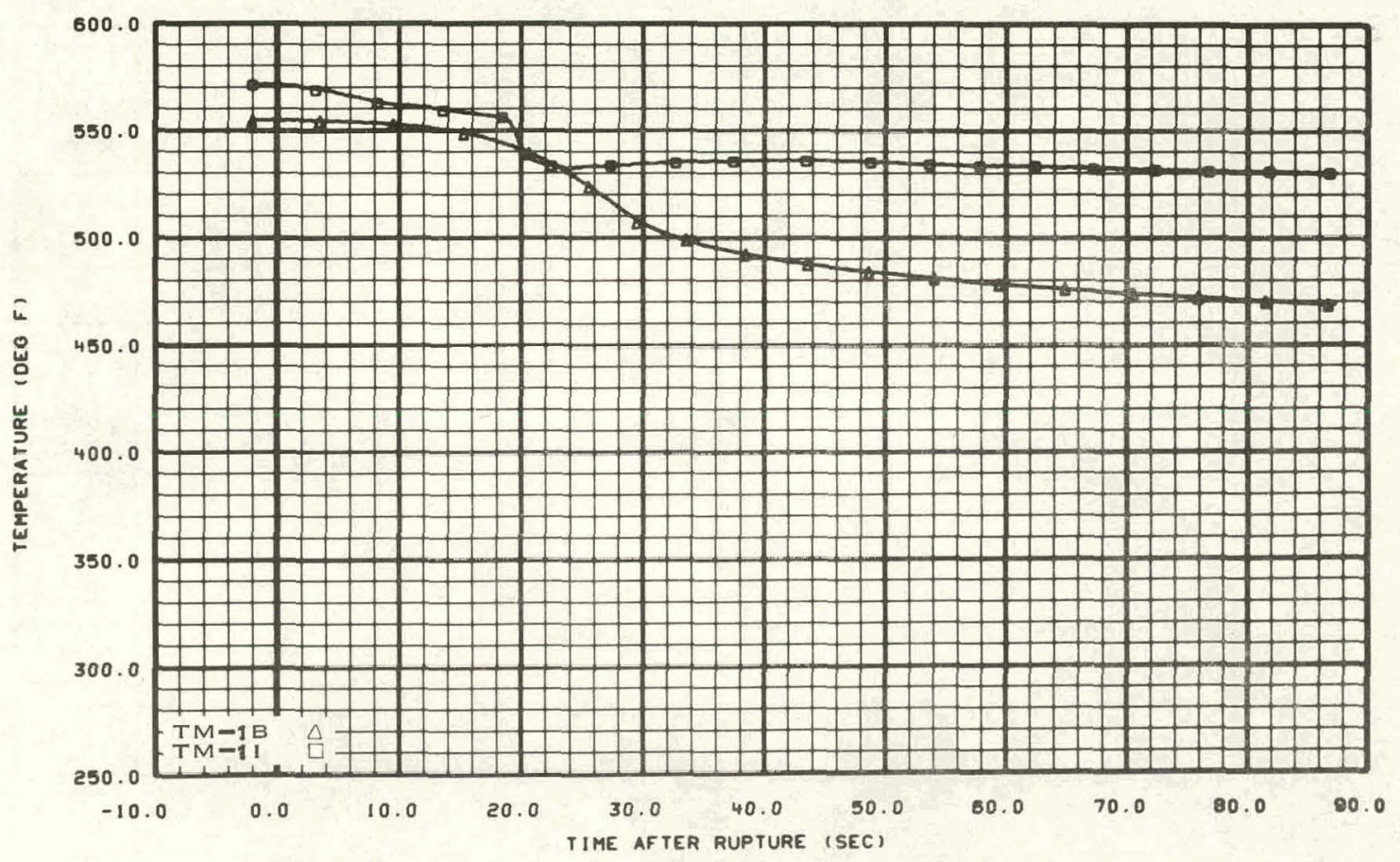

Fig. 16 Metal temperatures in operating loop hot leg Spool 1. 


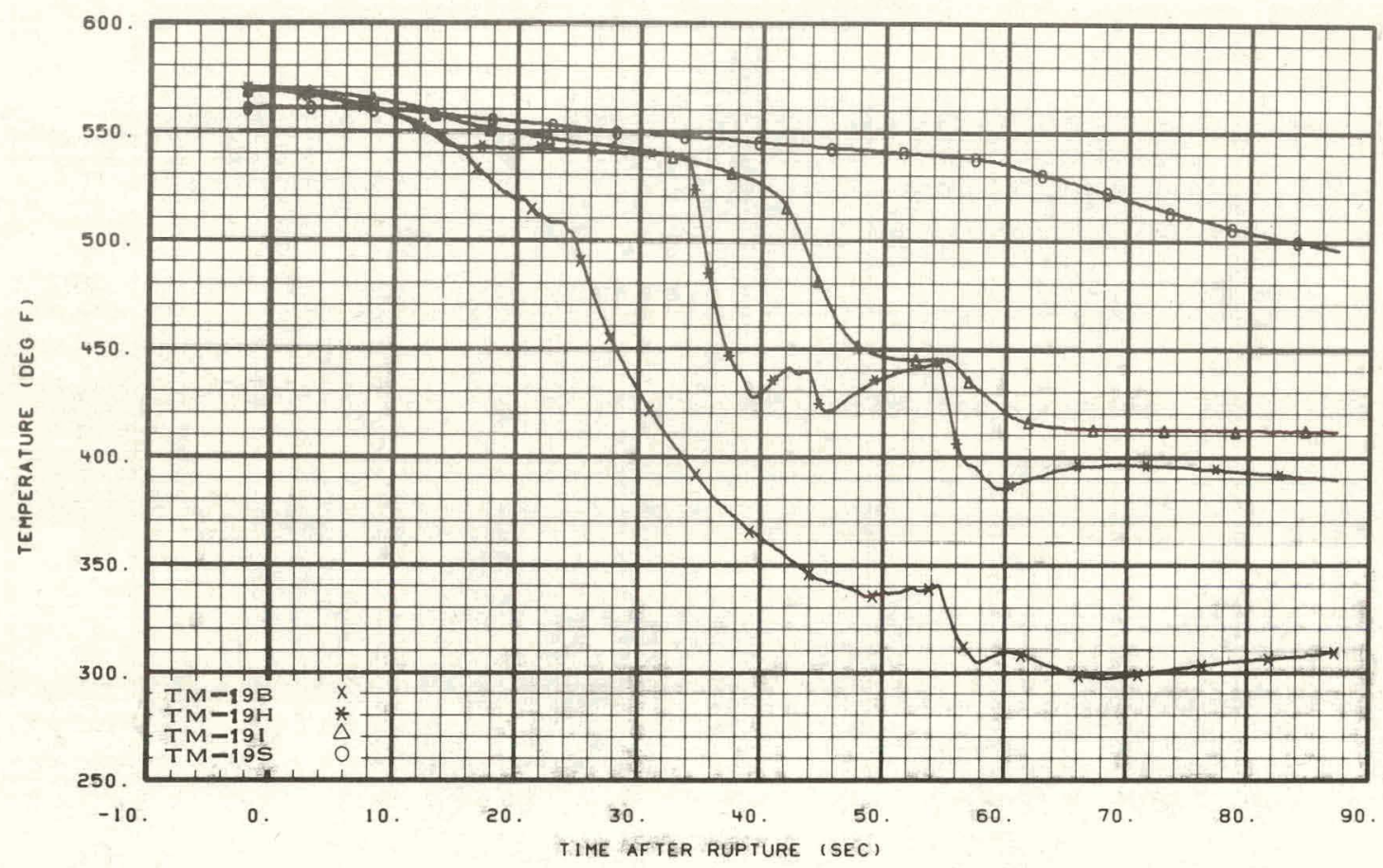

Fig. 17 Metal temperatures in operating loop cold leg Spool 19.

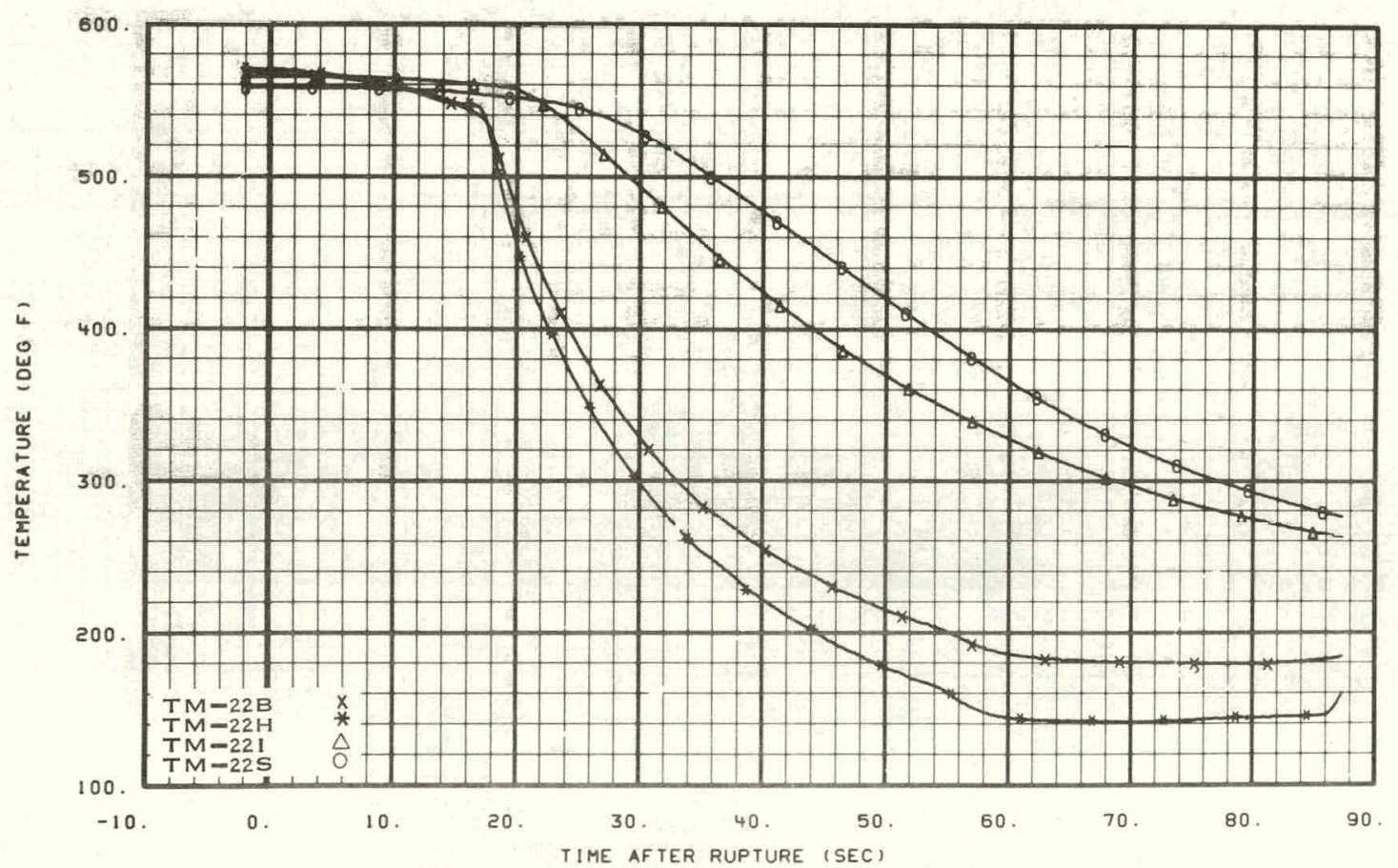

Fig. 18 Metal temperatures in operating loop cold leg Spool 22. 


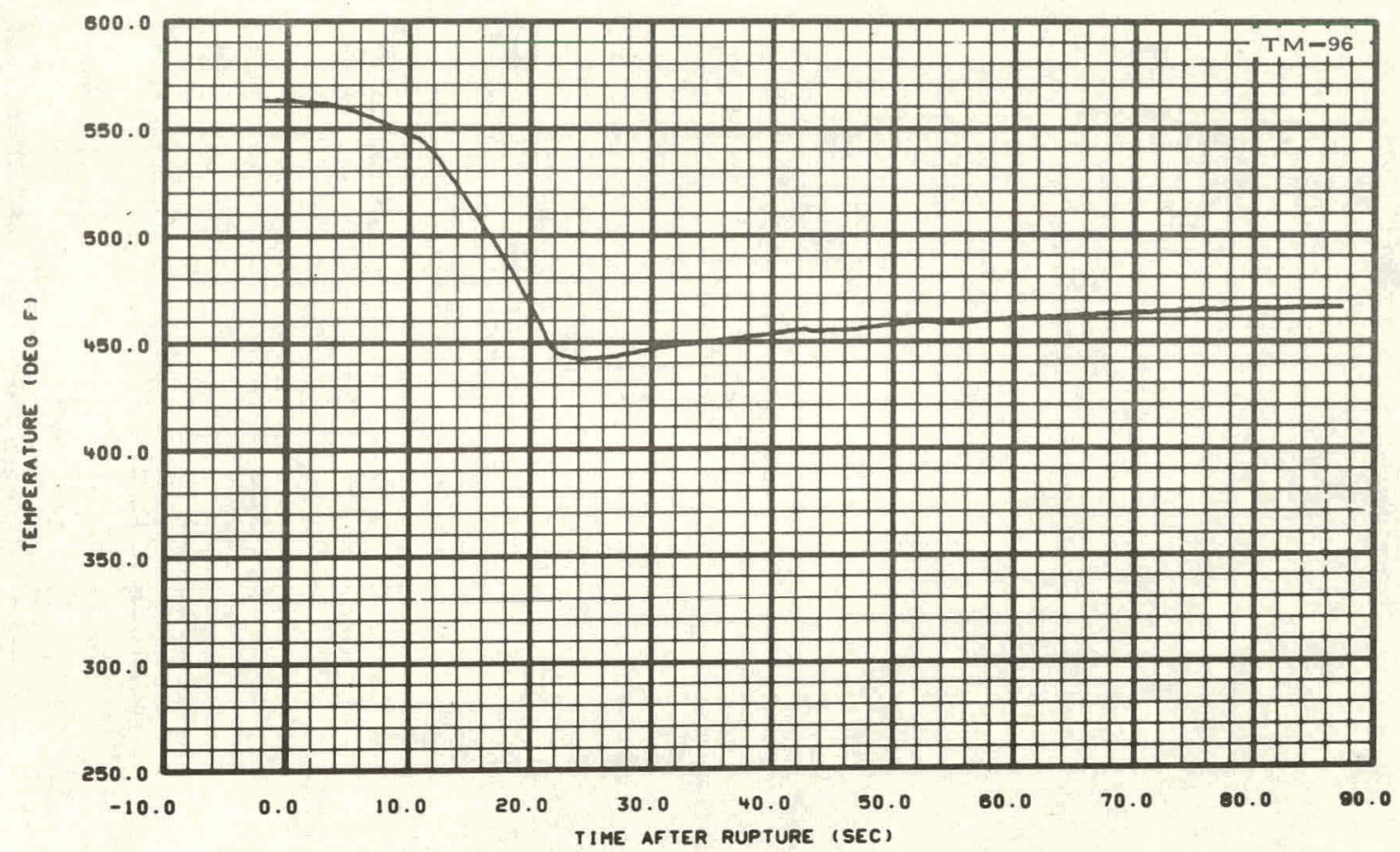

Fig. 19 Metal temperatures in blowdown loop.

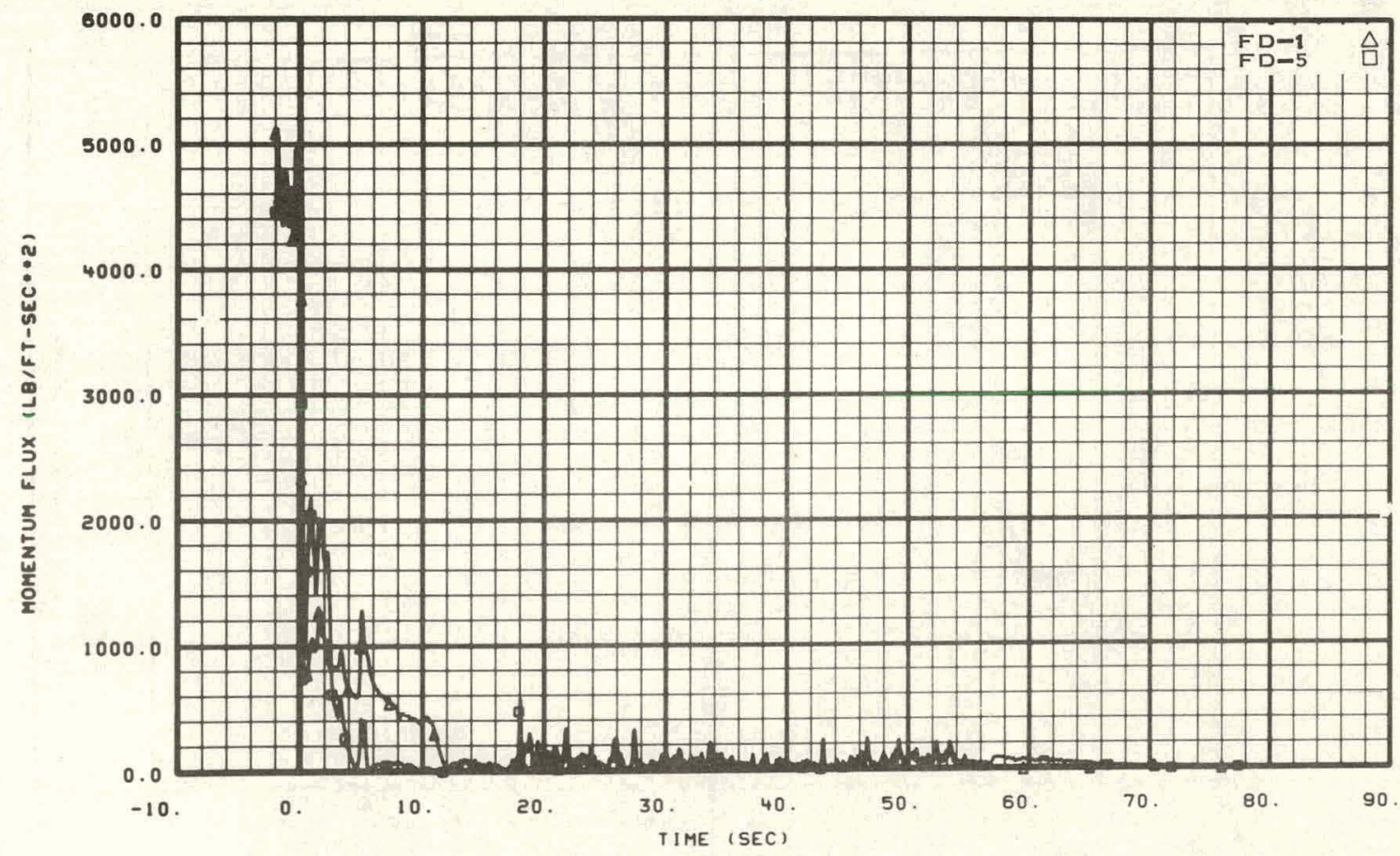

Fig. 20 Momentum flux from drag discs in operating loop hot leg. 


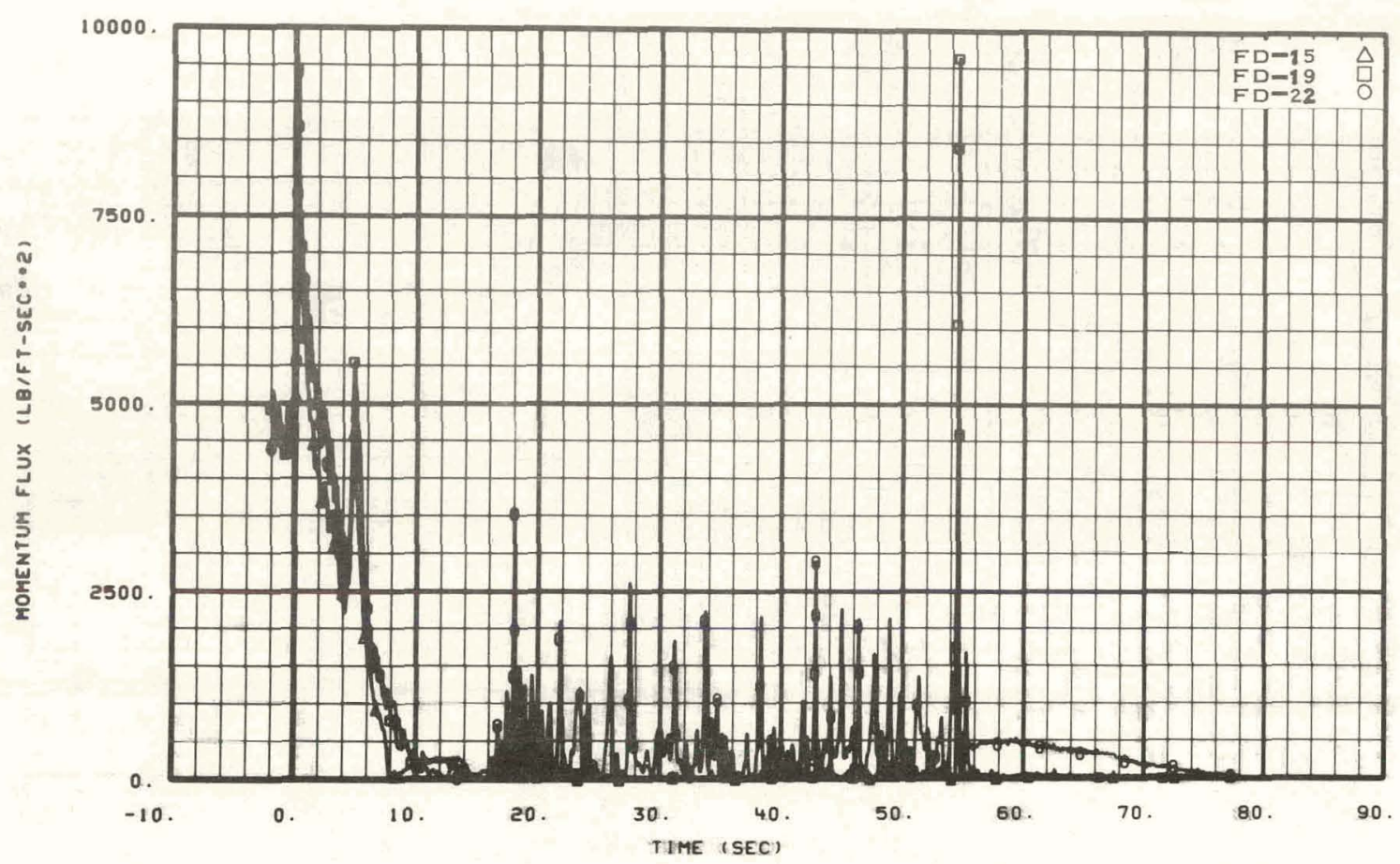

Fig. 21 Momentum flux from drag discs in operating loop cold leg.

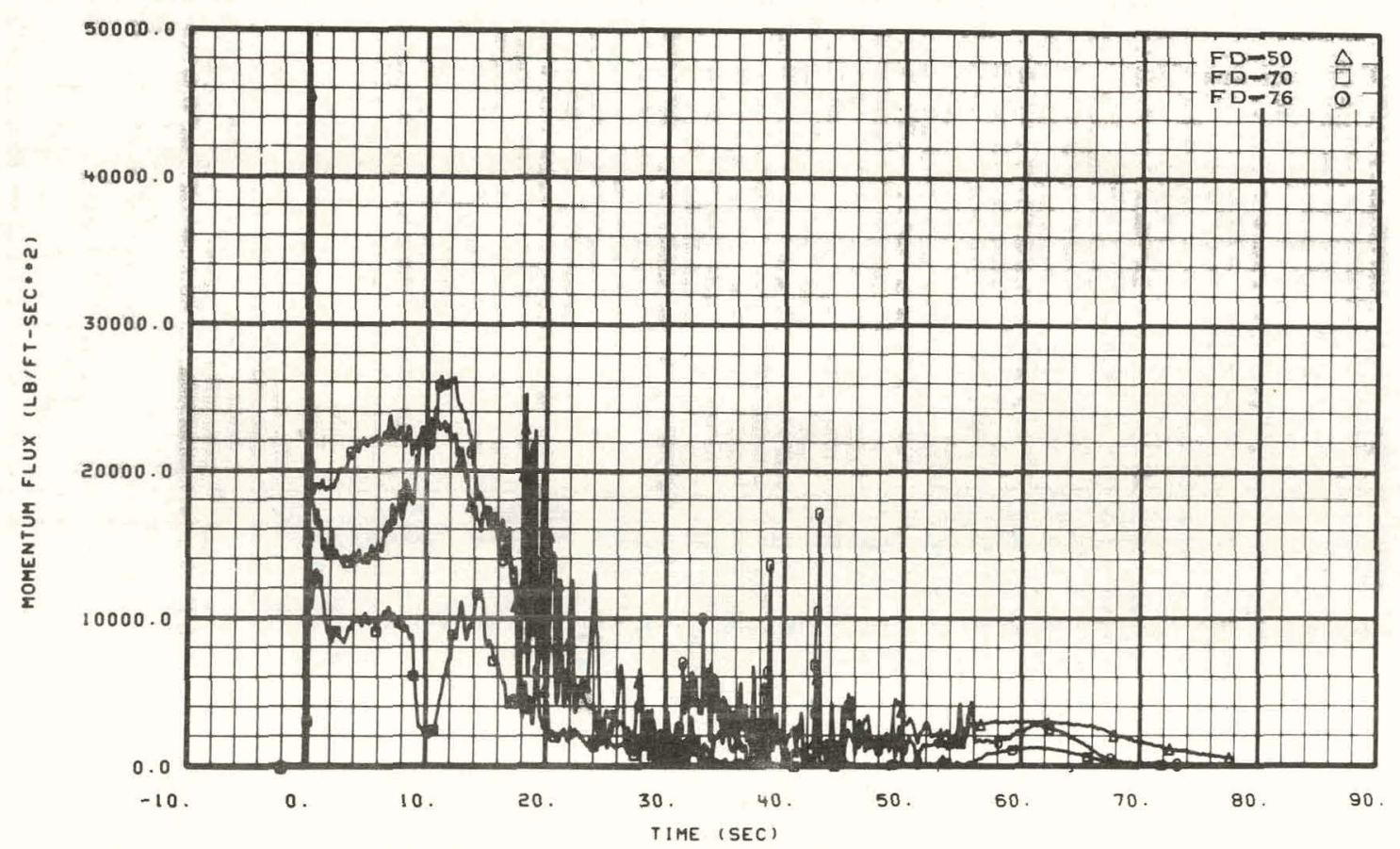

Fig. 22 Momentum flux from drag discs in blowdown loop. 


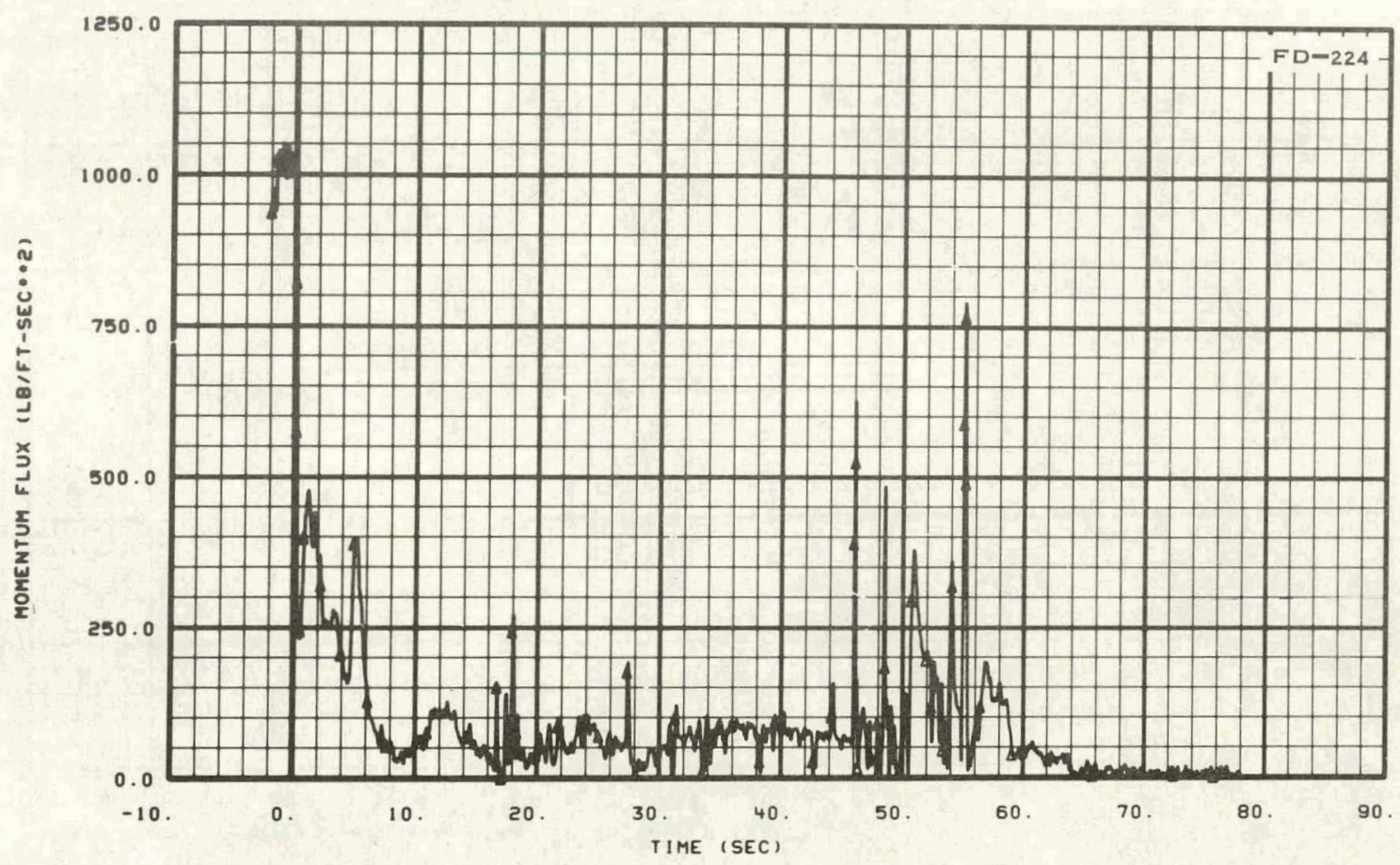

Fig. 23 Momentum flux from drag discs at core barrel inlet.

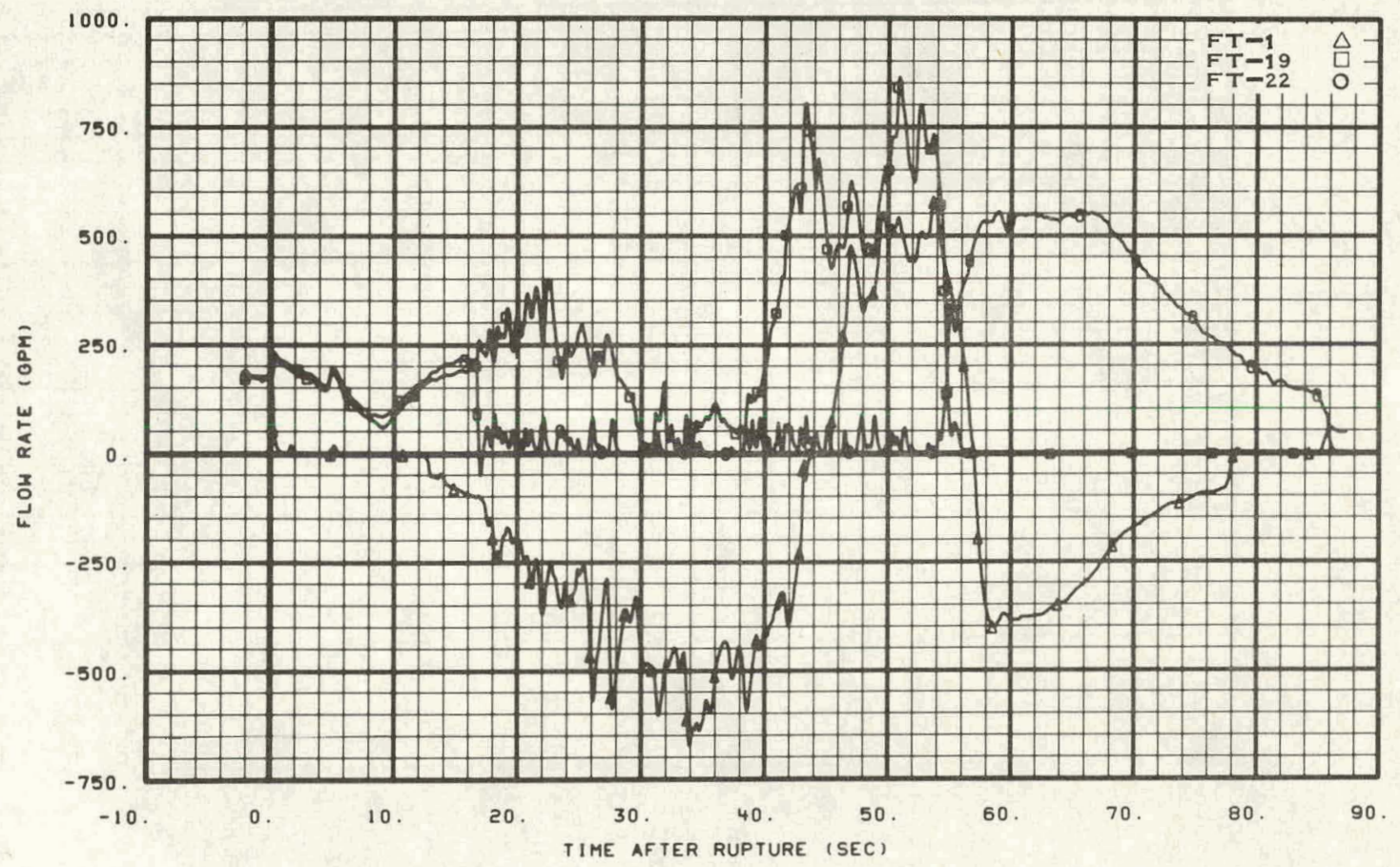

Fig. 24 Volumetric flow rate from turbine meters in operating loop. 


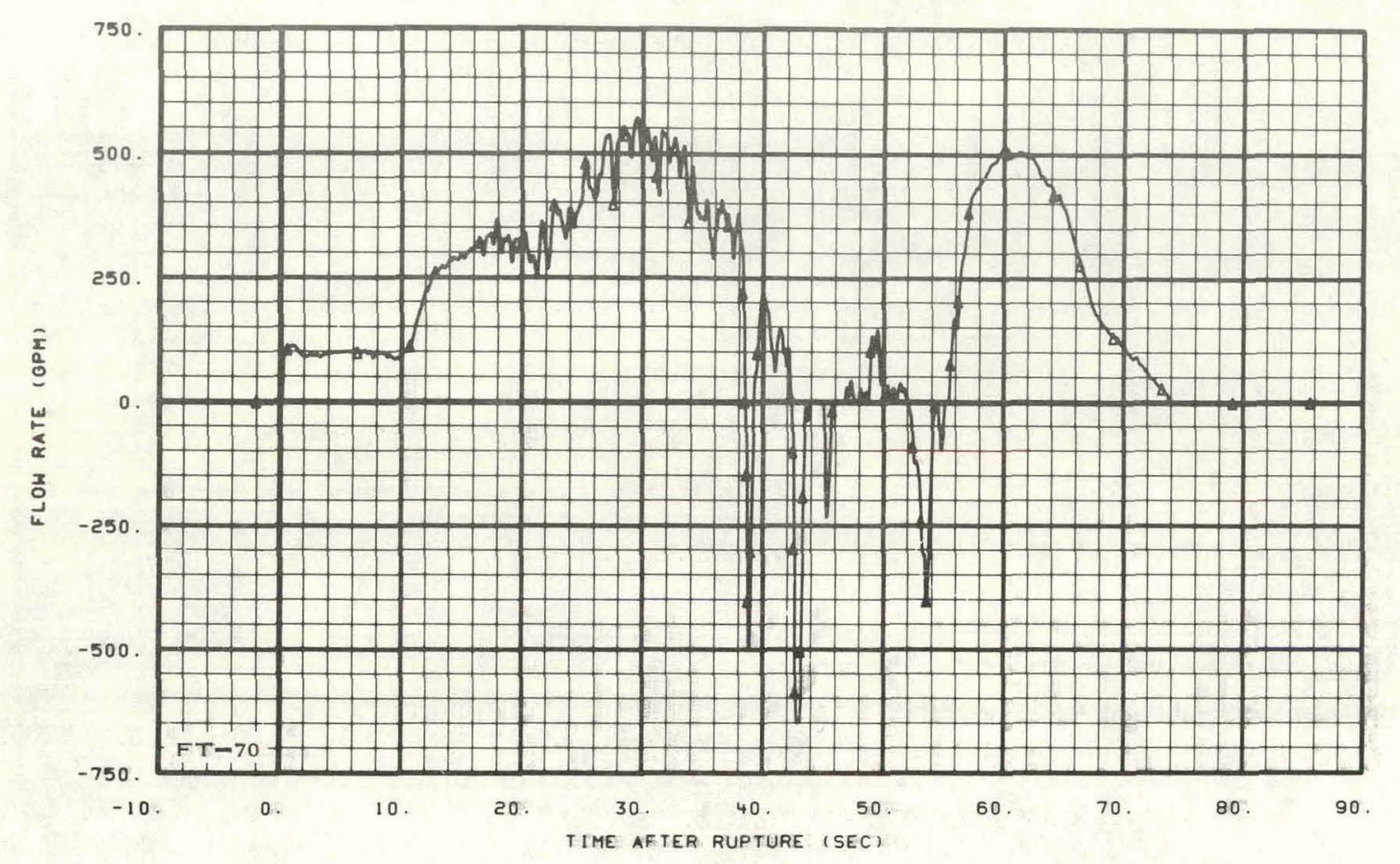

Fig. 25 Volumetric flow rate from turbine meter in blowdown loop hot leg.

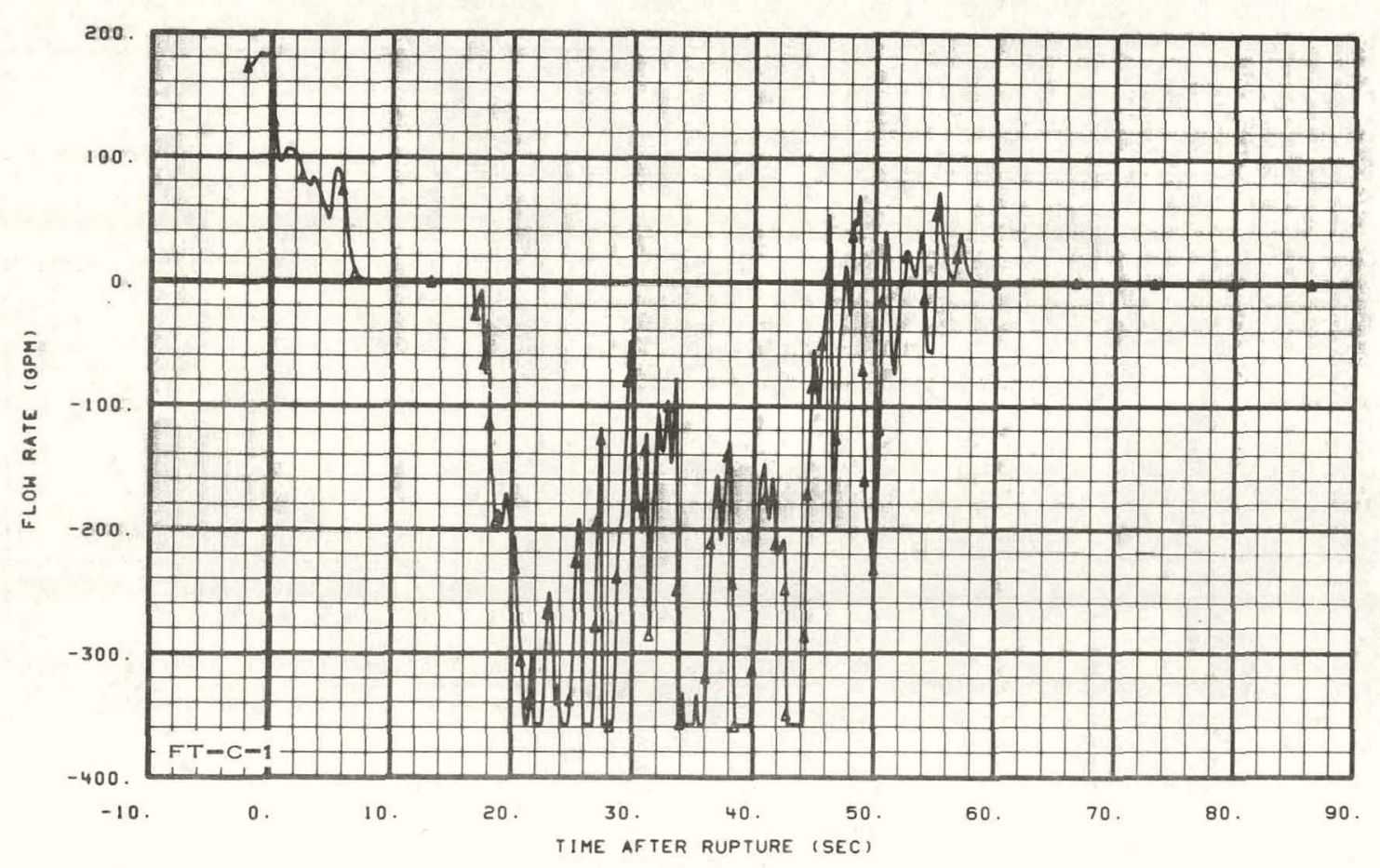

Fig. 26 Volumetric flow rate from turbine meter at core barrel inlet. 


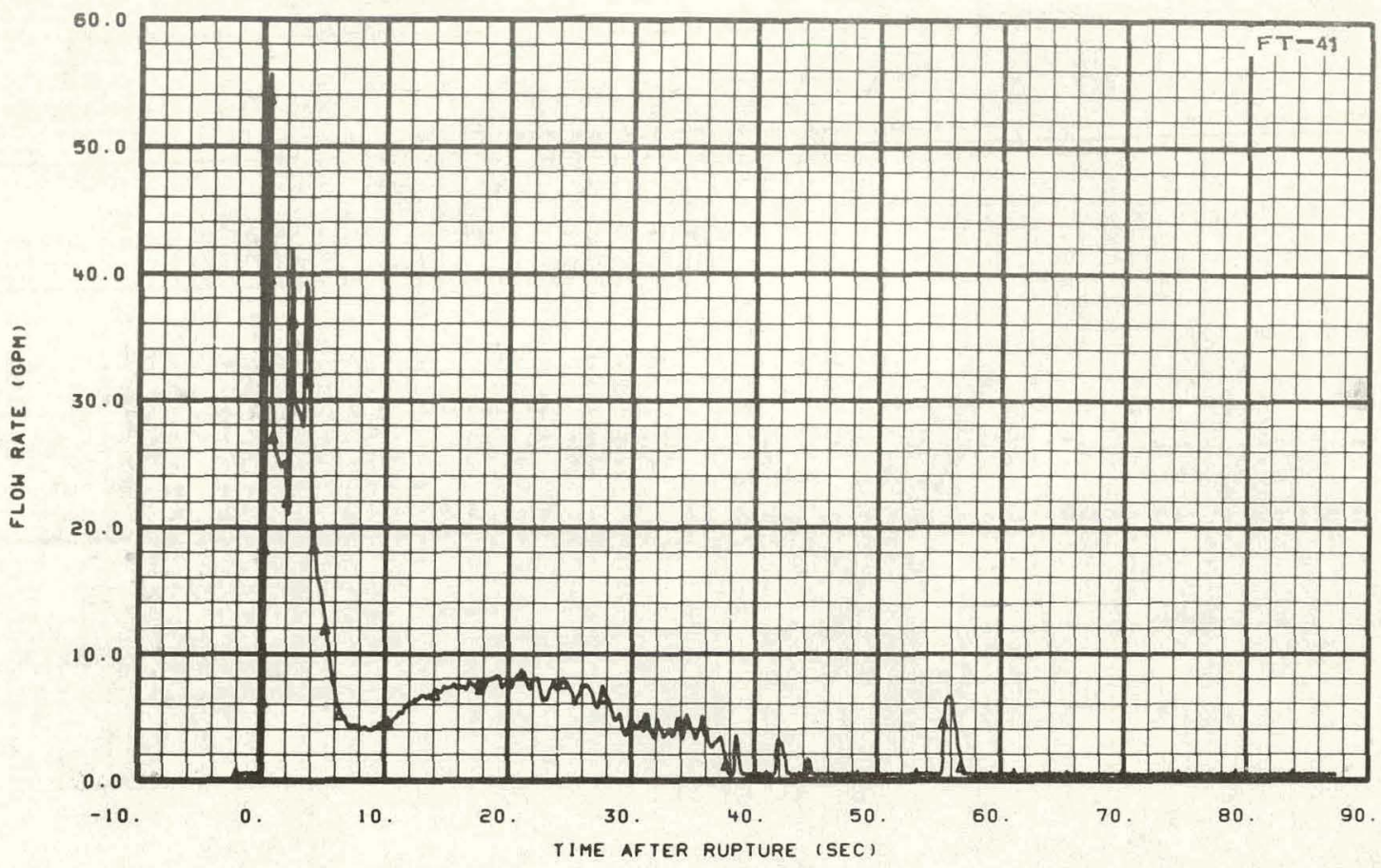

Fig. 27 Volumetric flow rate from turbine meter at pressurizer outlet.

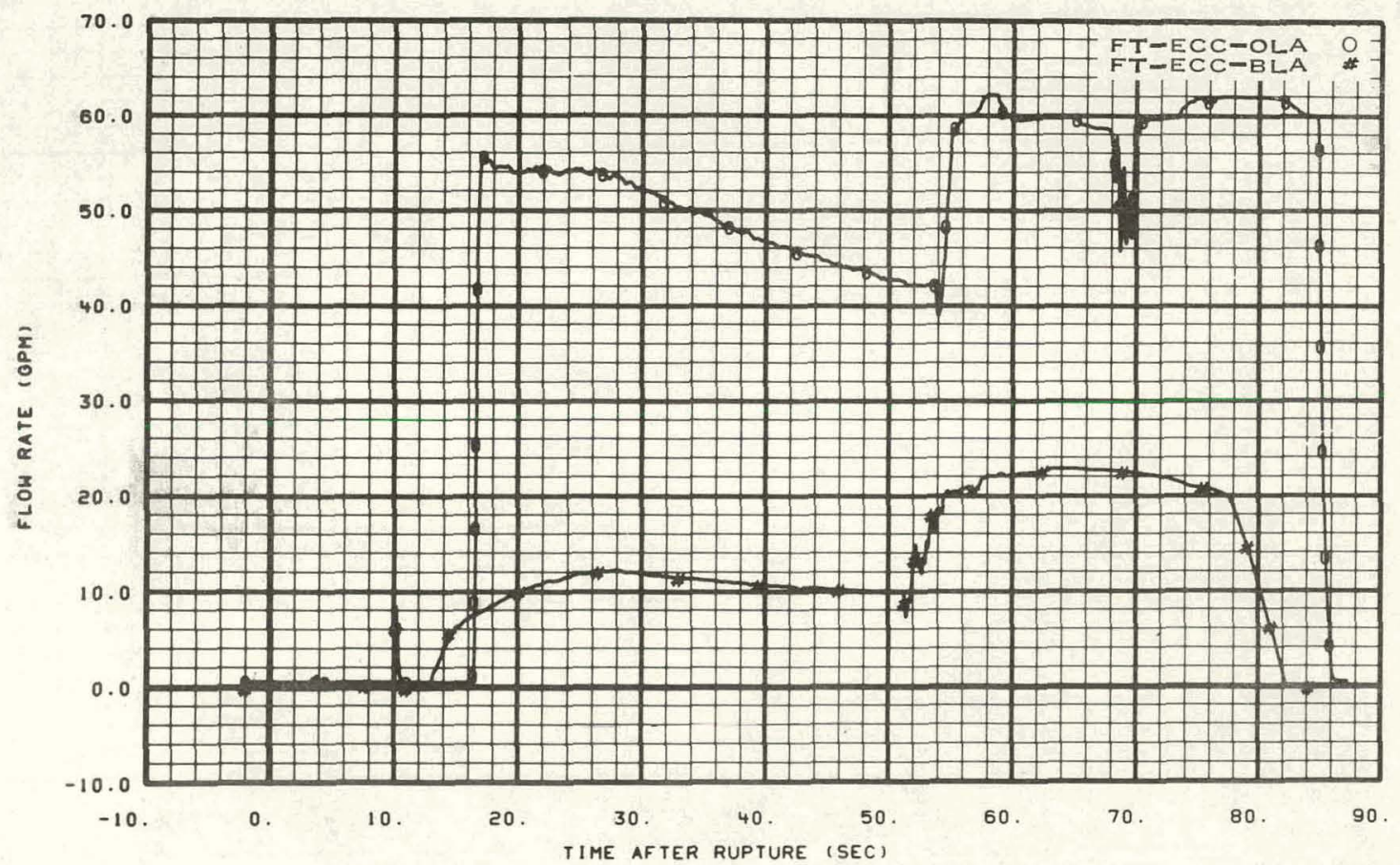

Fig. 28 Volumetric flow rate from ECC accumulator tanks in operating and blowdown loops (turbine meters). 


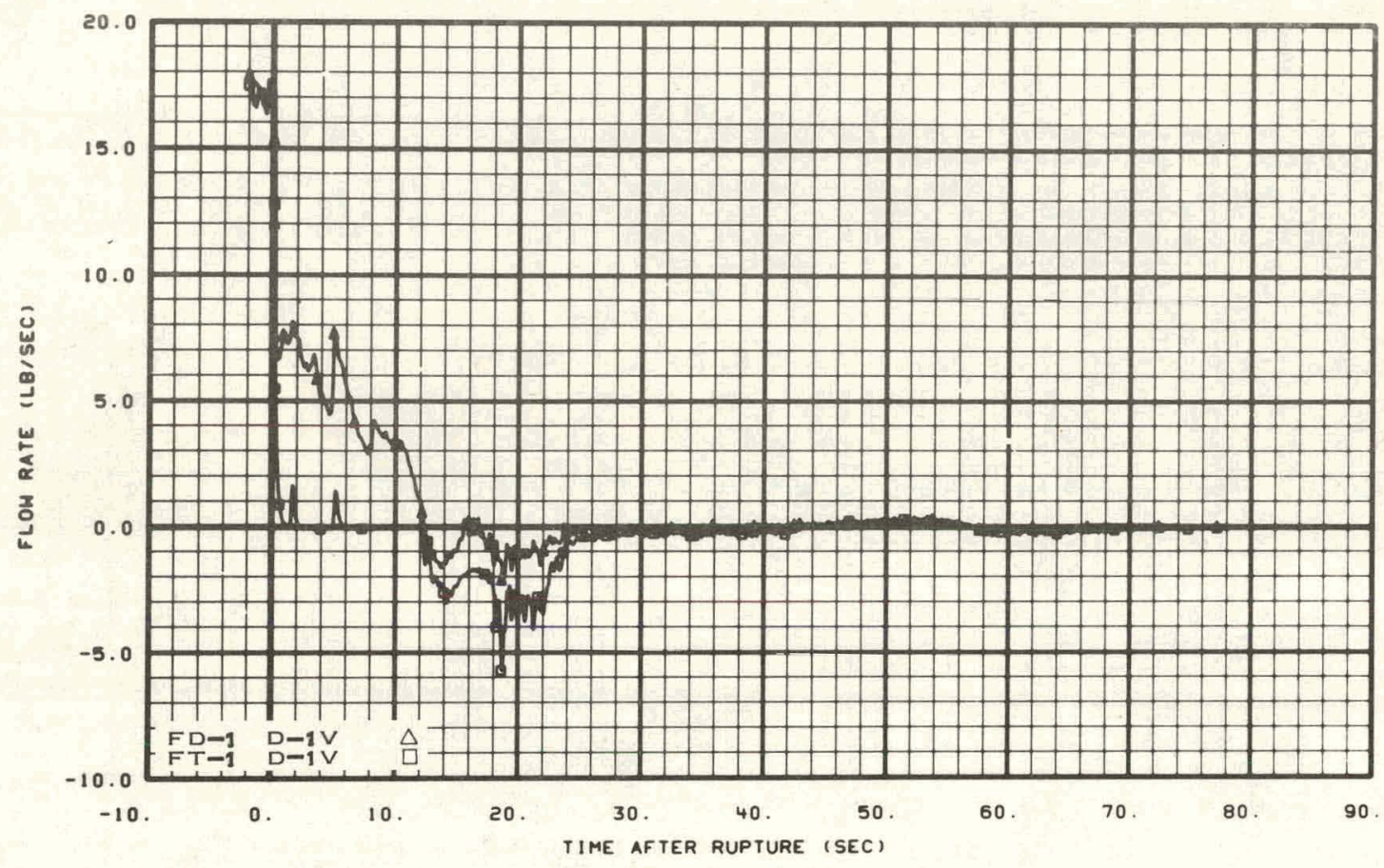

Fig. 29 Mass flow rate in operating loop hot leg Spool 1.

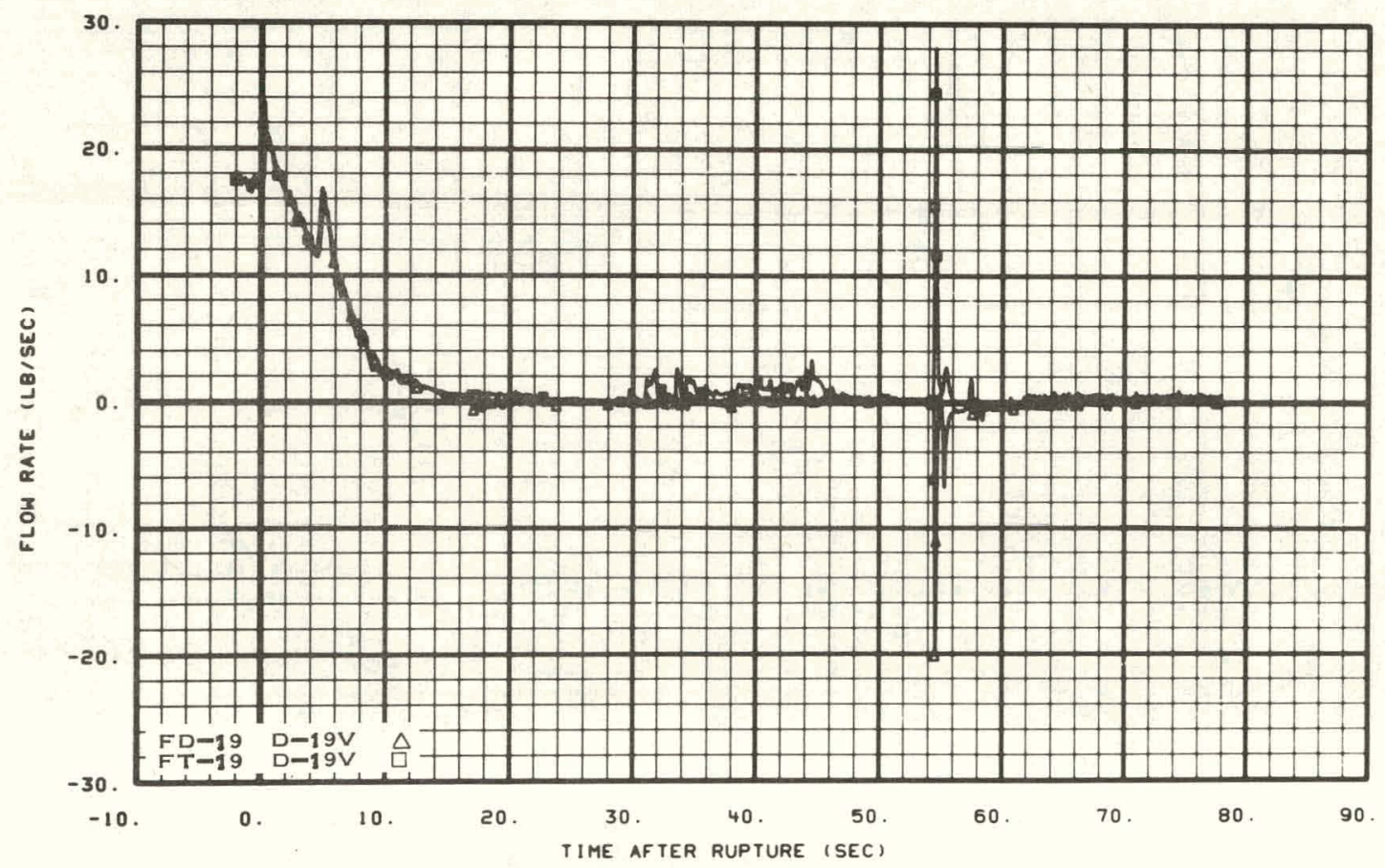

Fig. 30 Mass flow rate in operating loop at pump discharge (Spool 19). 


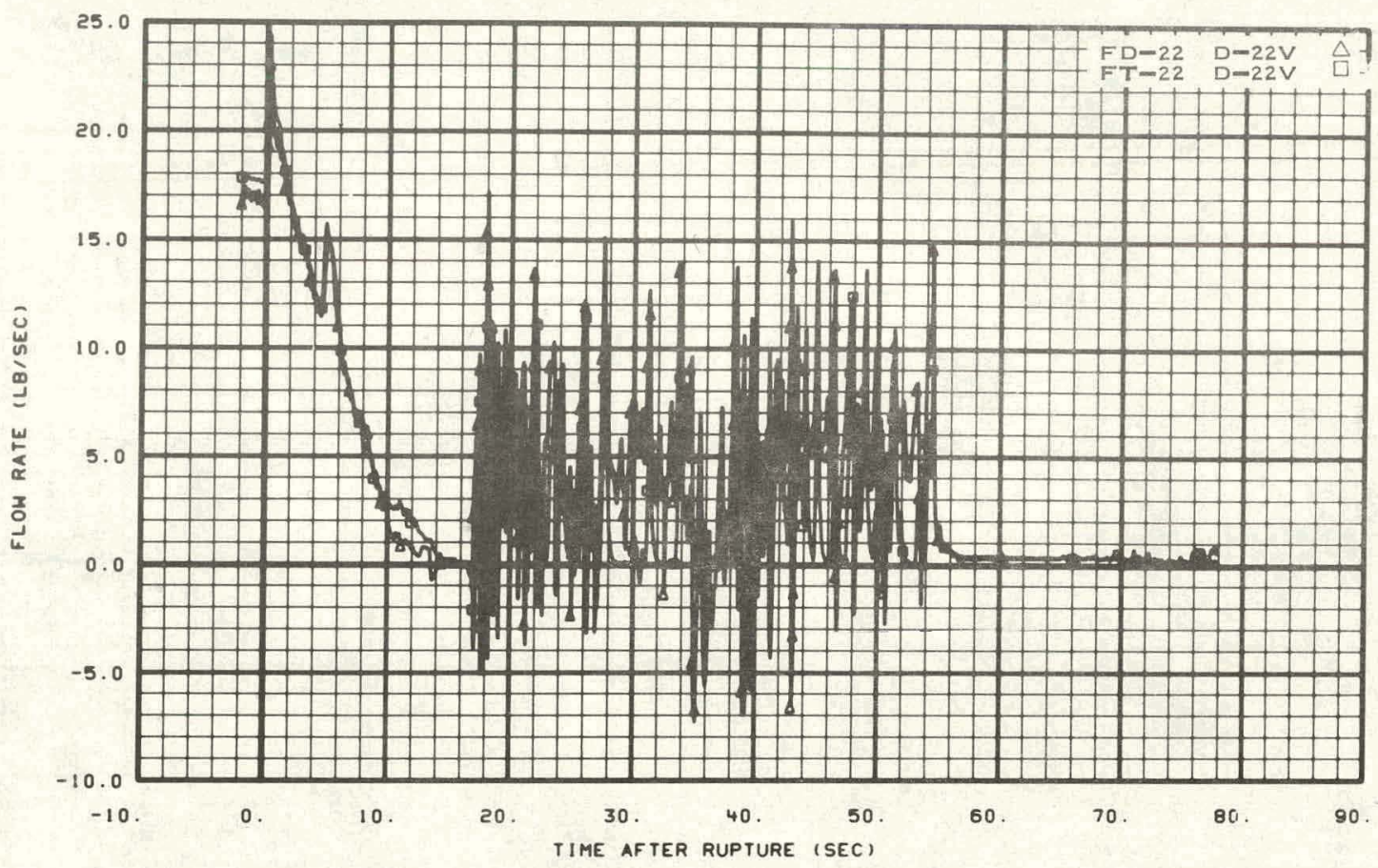

Fig. 31 Mass flow rate in operating loop cold leg Spool 22.

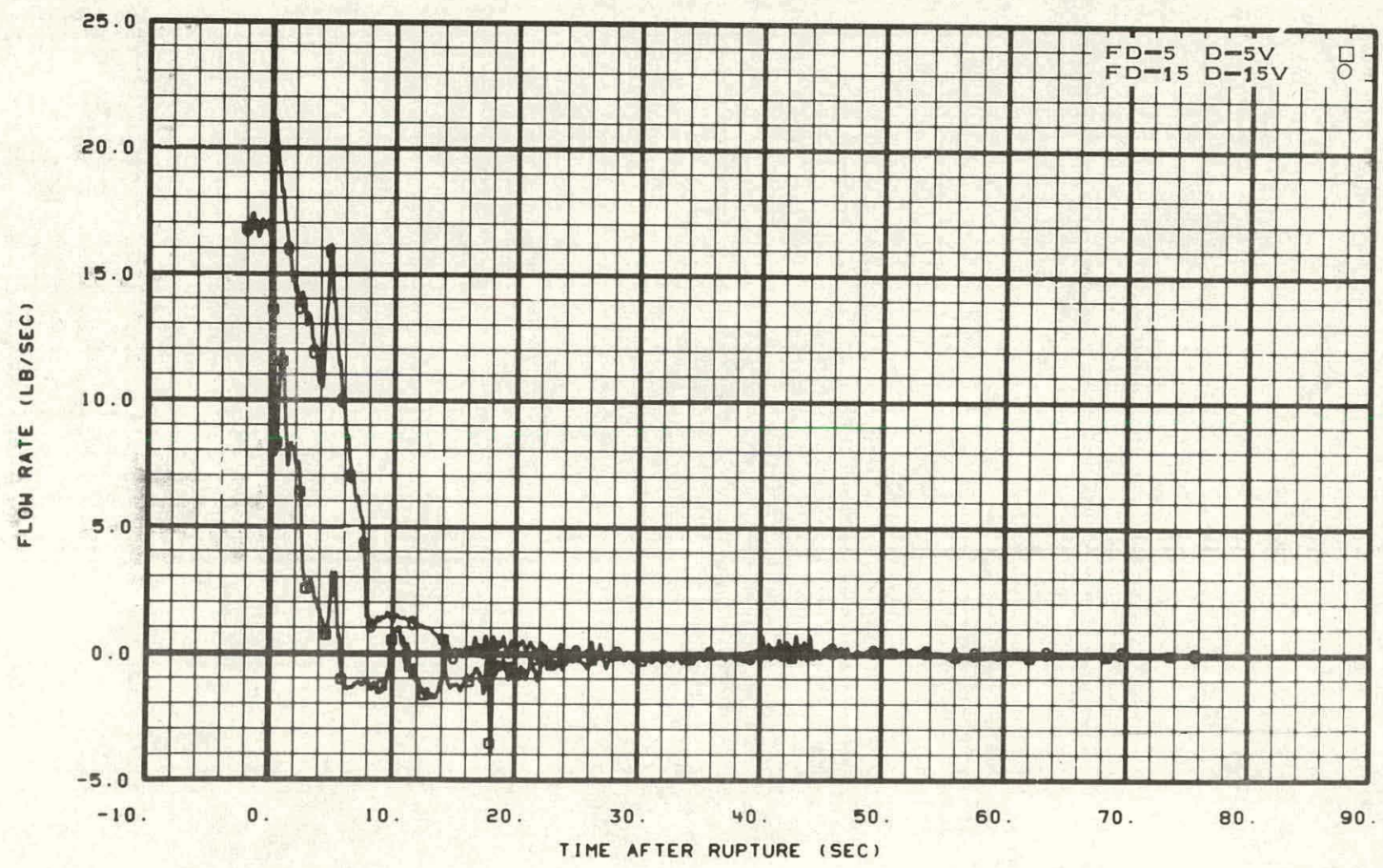

Fig. 32 Mass flow rate in operating loop Spools 5 and 15. 


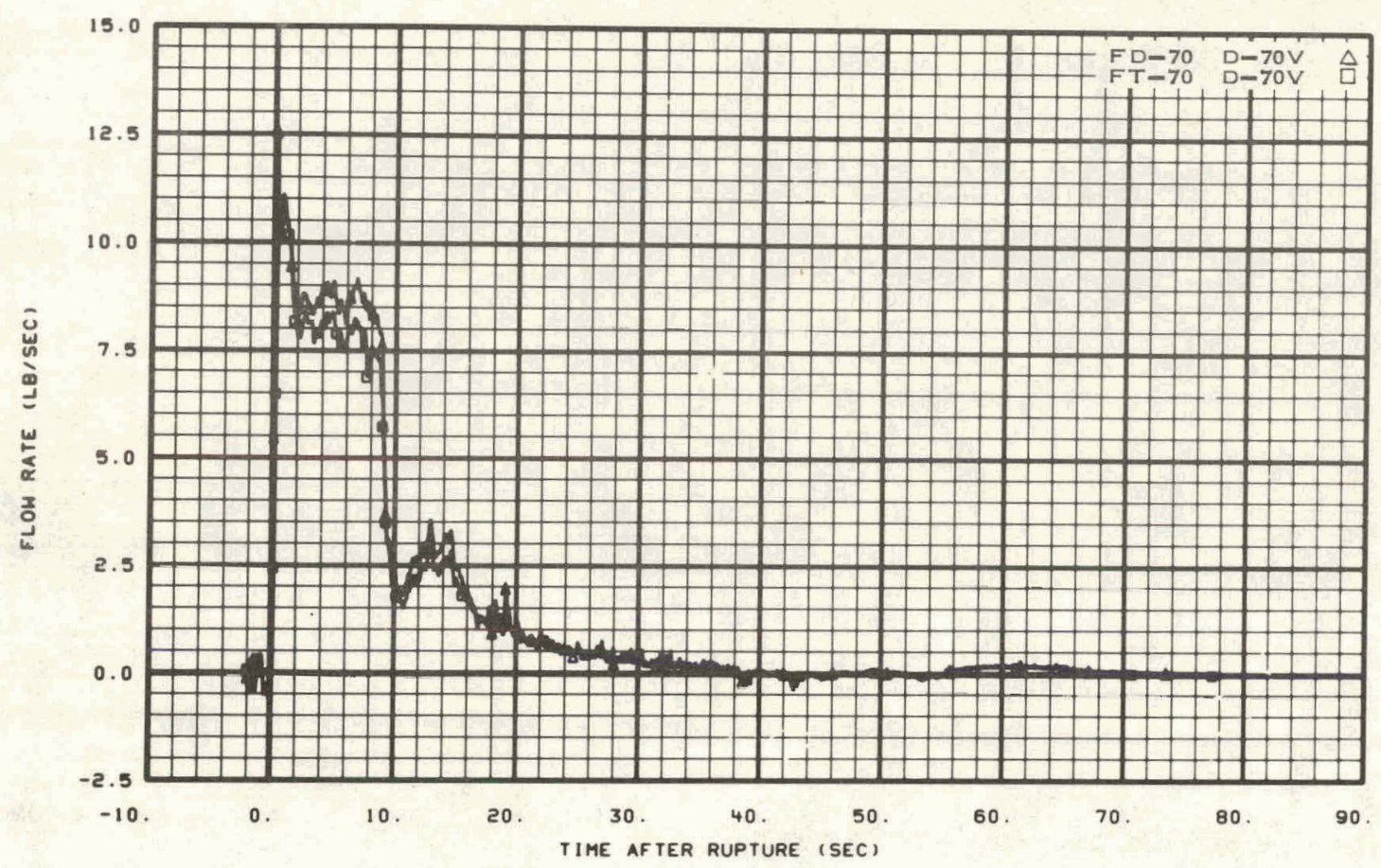

Fig. 33 Mass flow rate in blowdown loop Spoo1 70.

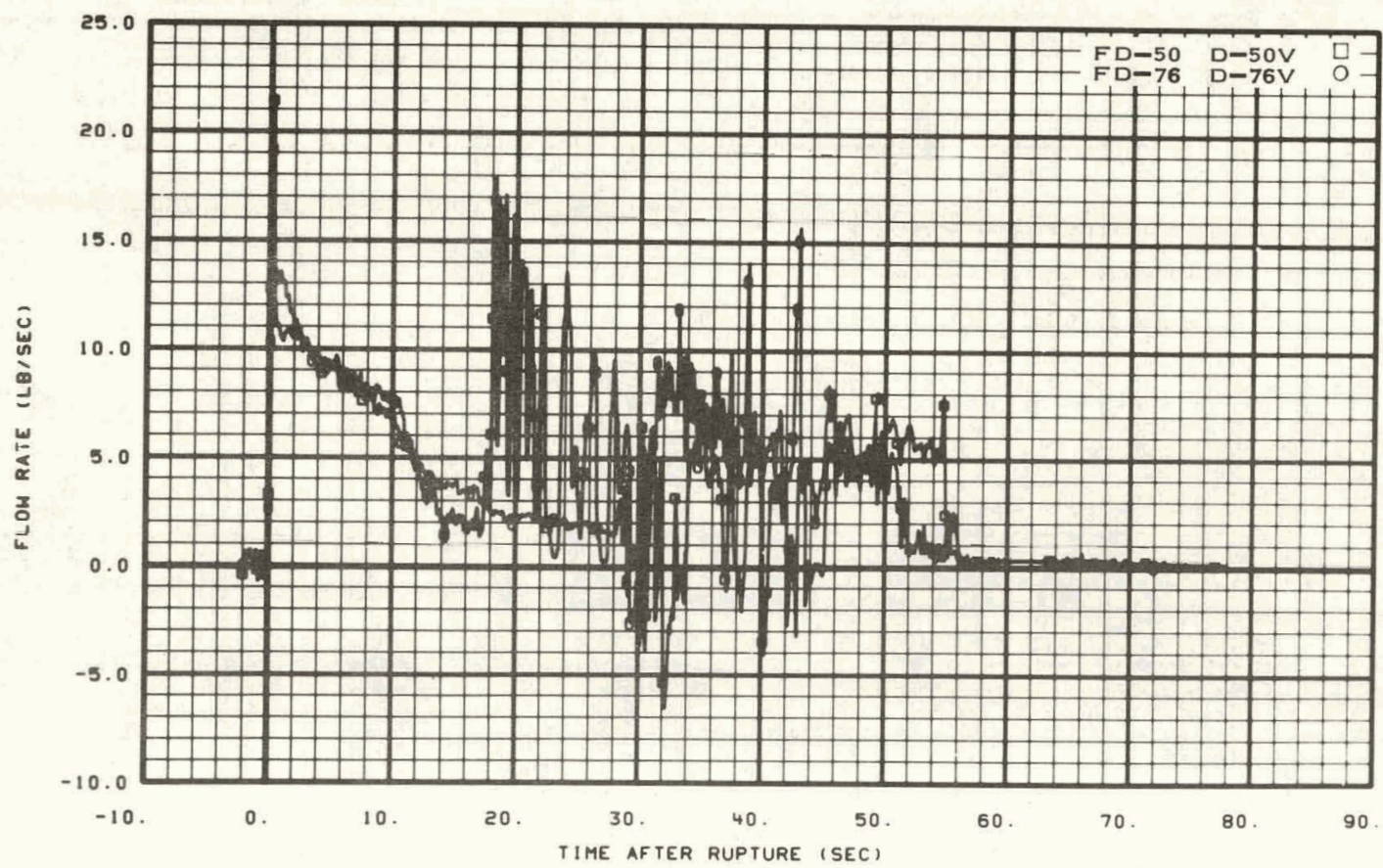

Fig. 34 Mass flow rate in blowdown 1oop spools 50 and 76 . 


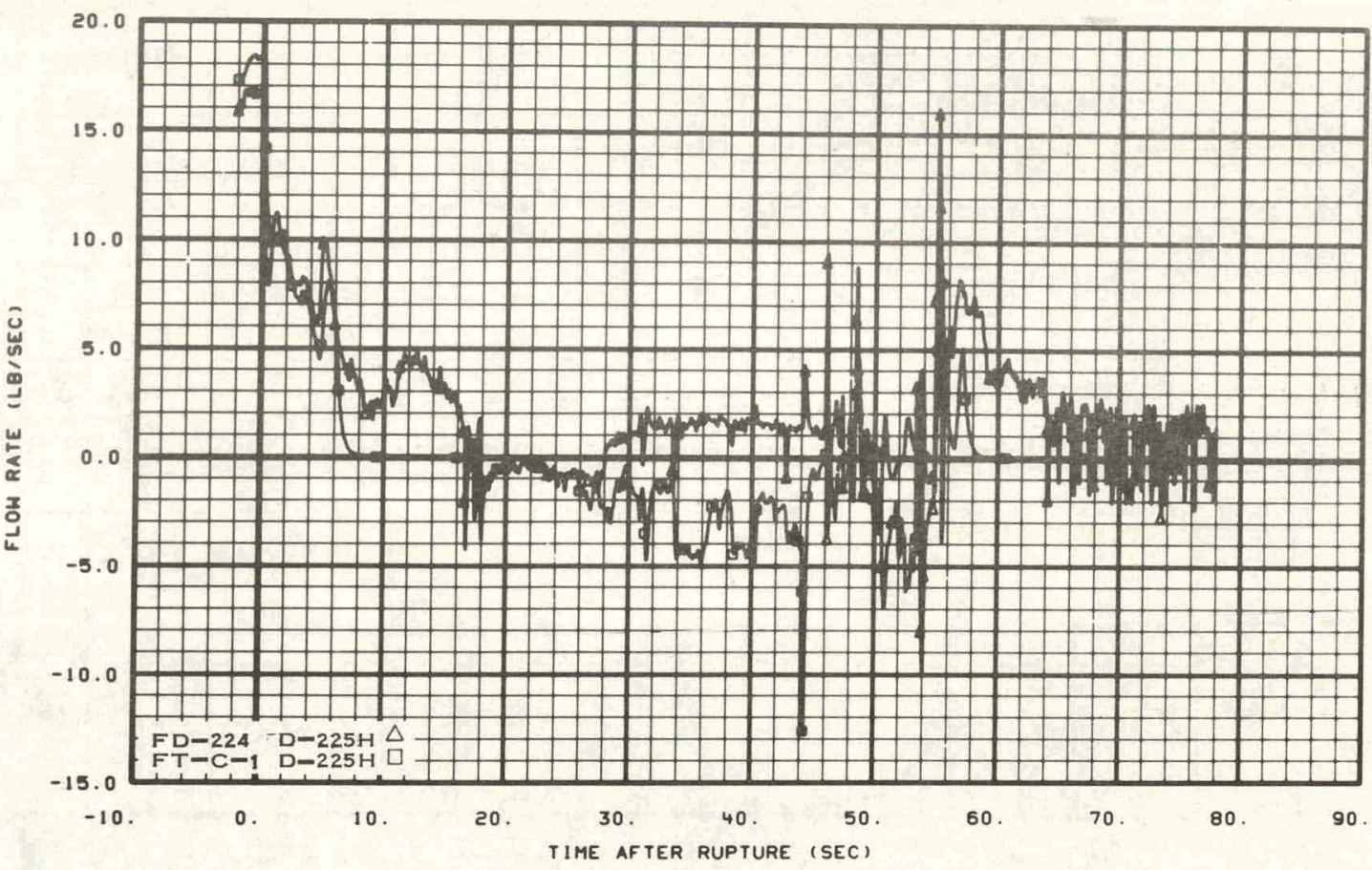

Fig. 35 Mass flow rate at core barrel inlet.

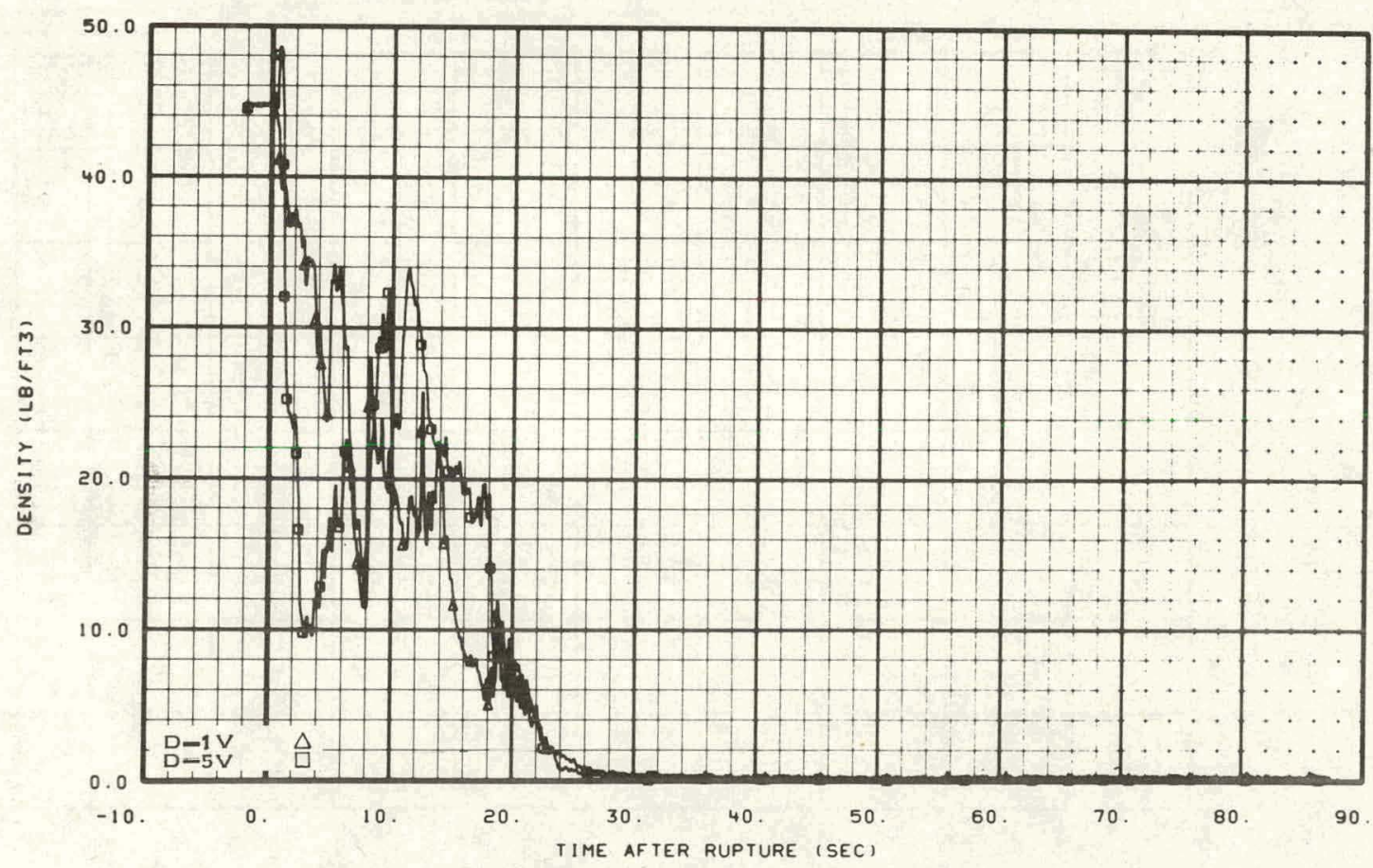

Fig. 36 Fluid denstty in operating loop hot leg. 


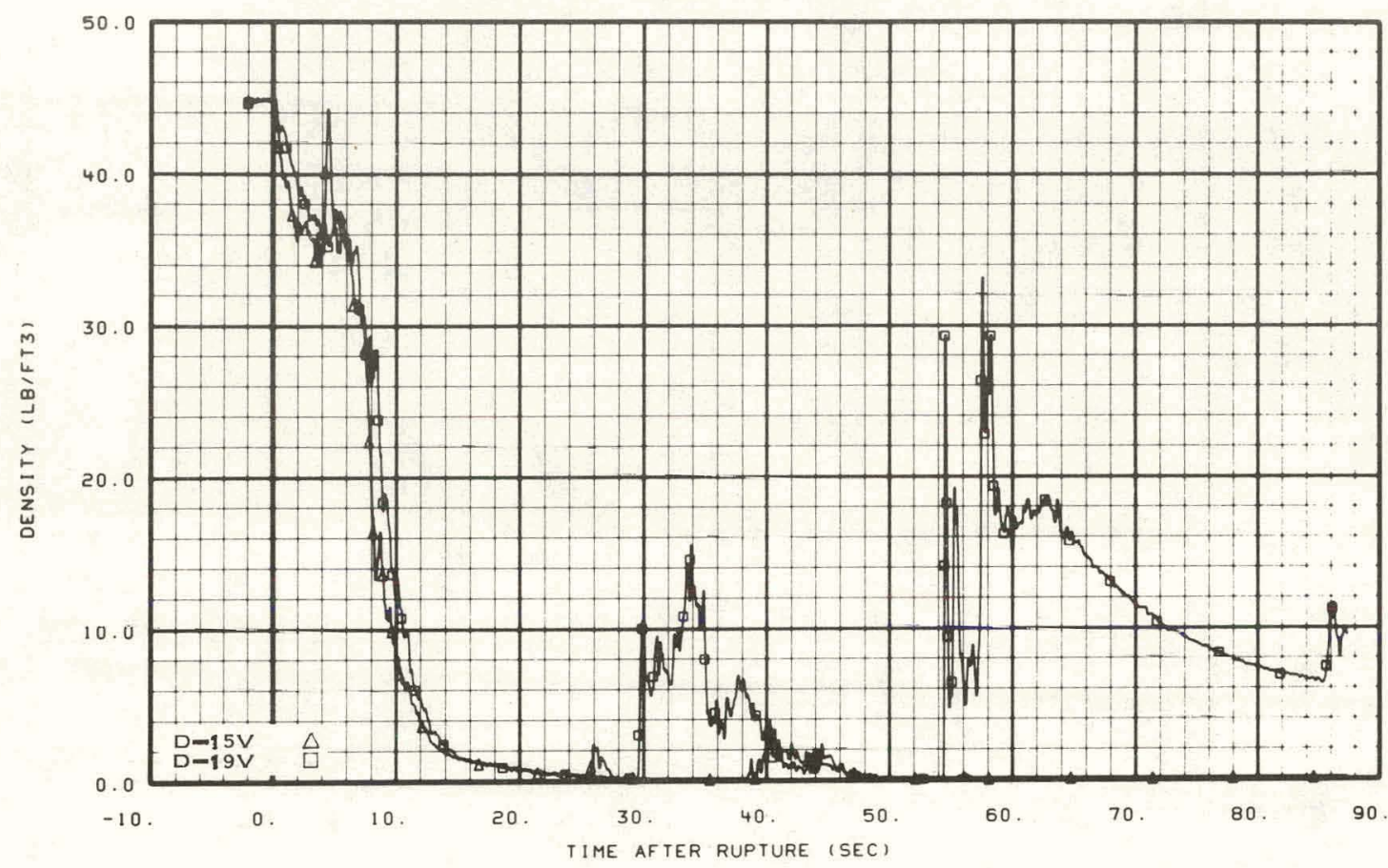

Fig. 37 Fluid density at operating loop pump inlet and outlet.

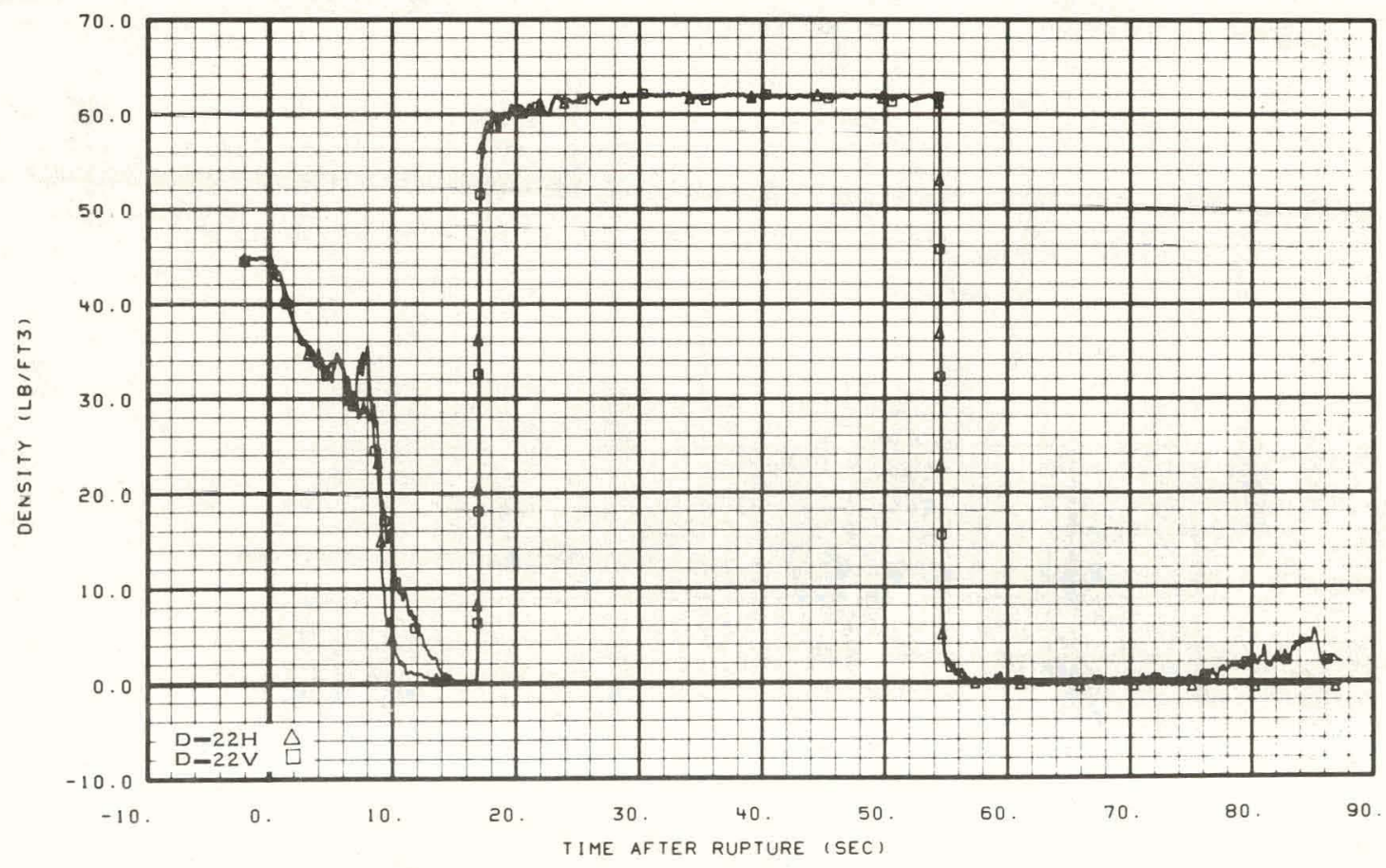

Fig. 38 Fluid density in operating loop cold leg. 


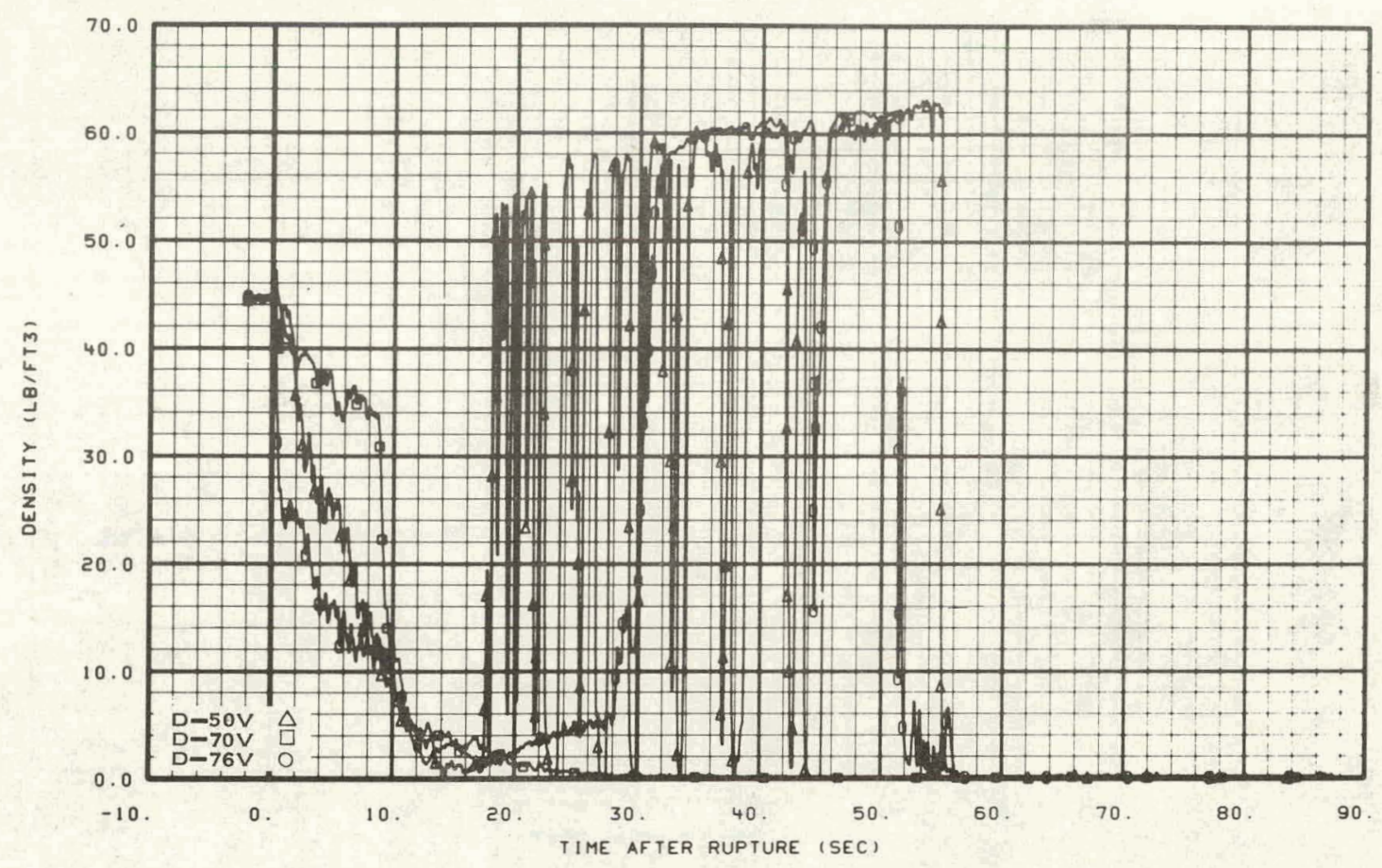

Fig. 39 Fluid density in blowdown loop.

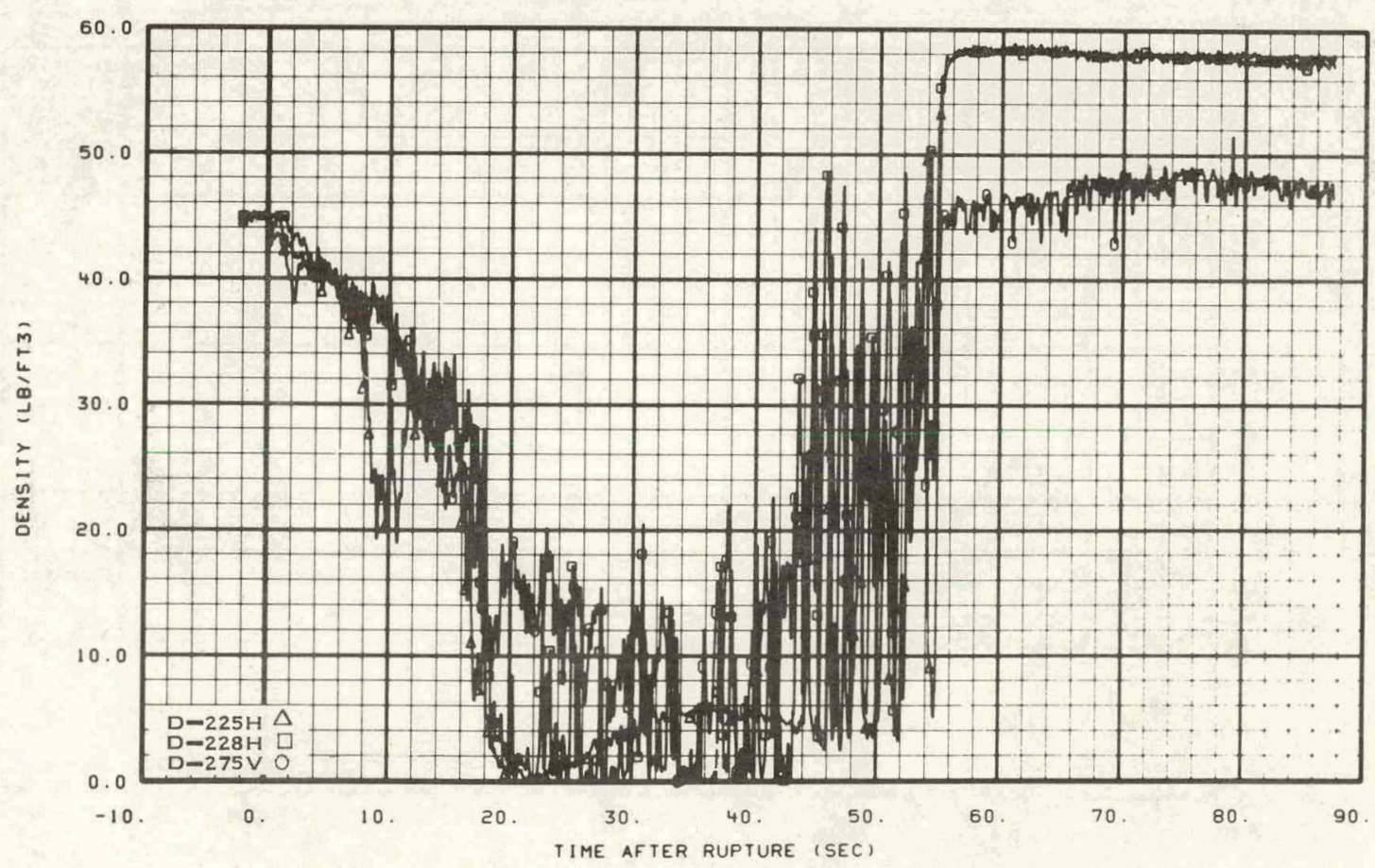

Fig. 40 Fluid density in vessel. 


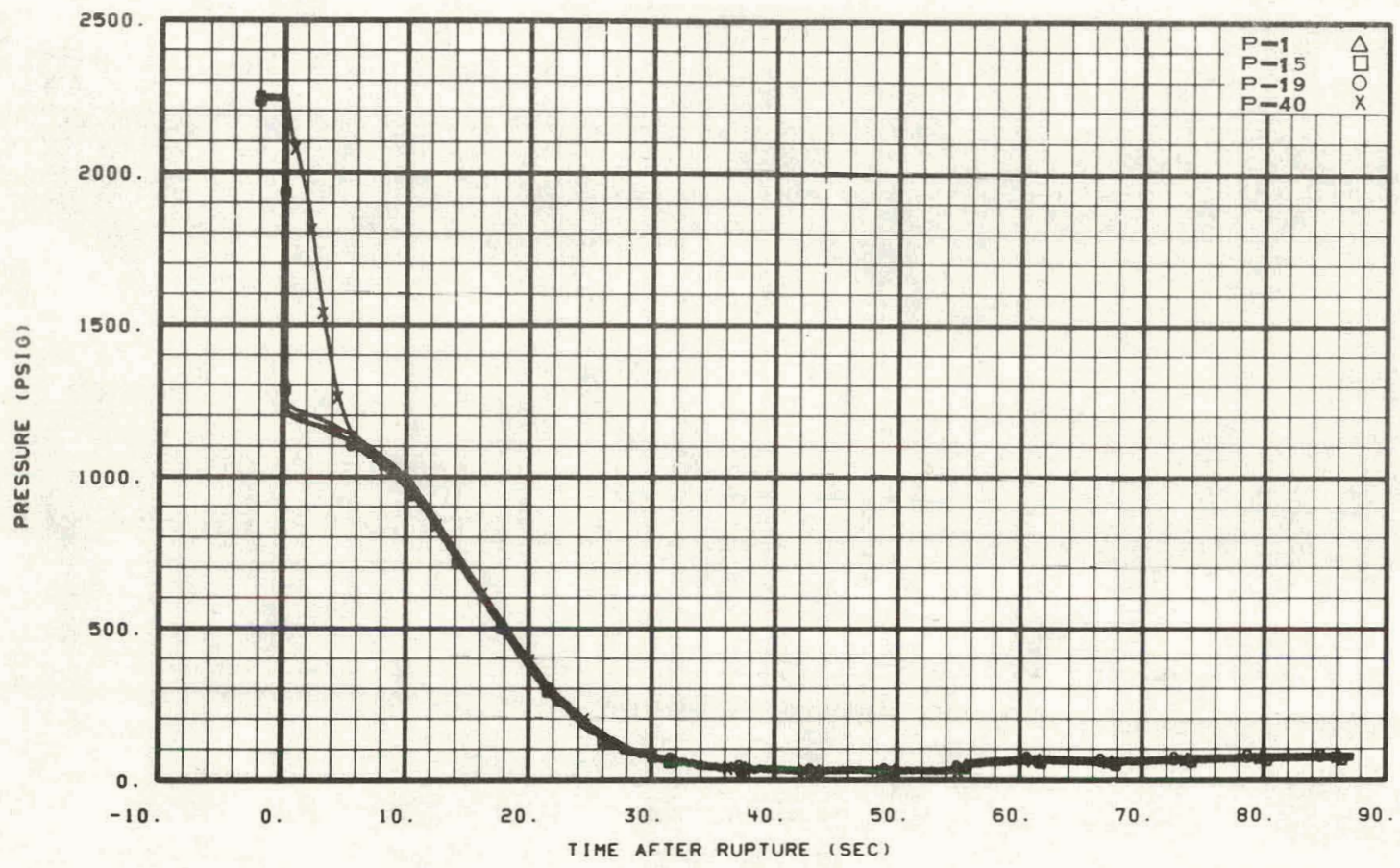

Fig. 41 Pressure in operating loop.

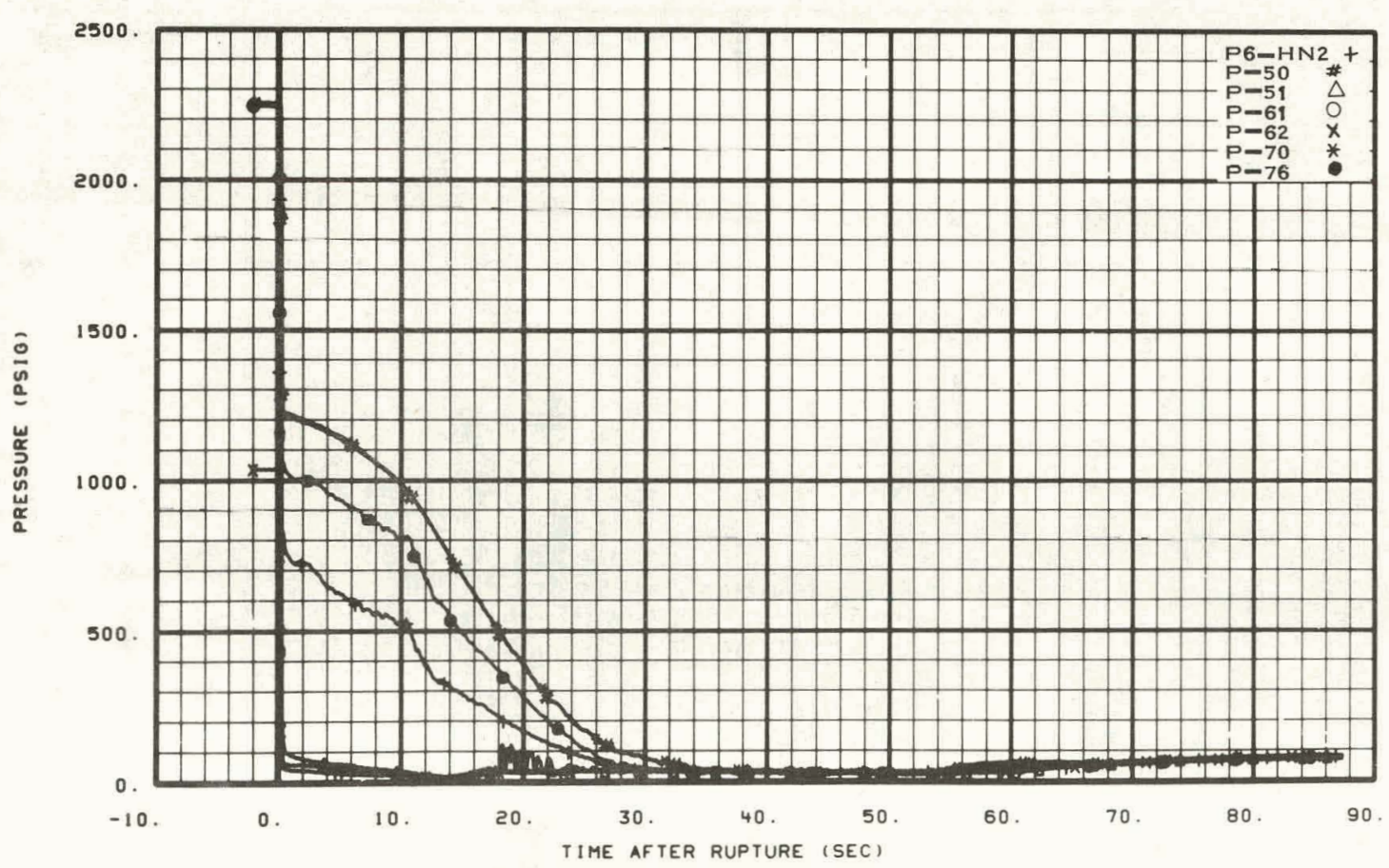

Fig. 42 Pressure in blowdown loop. 


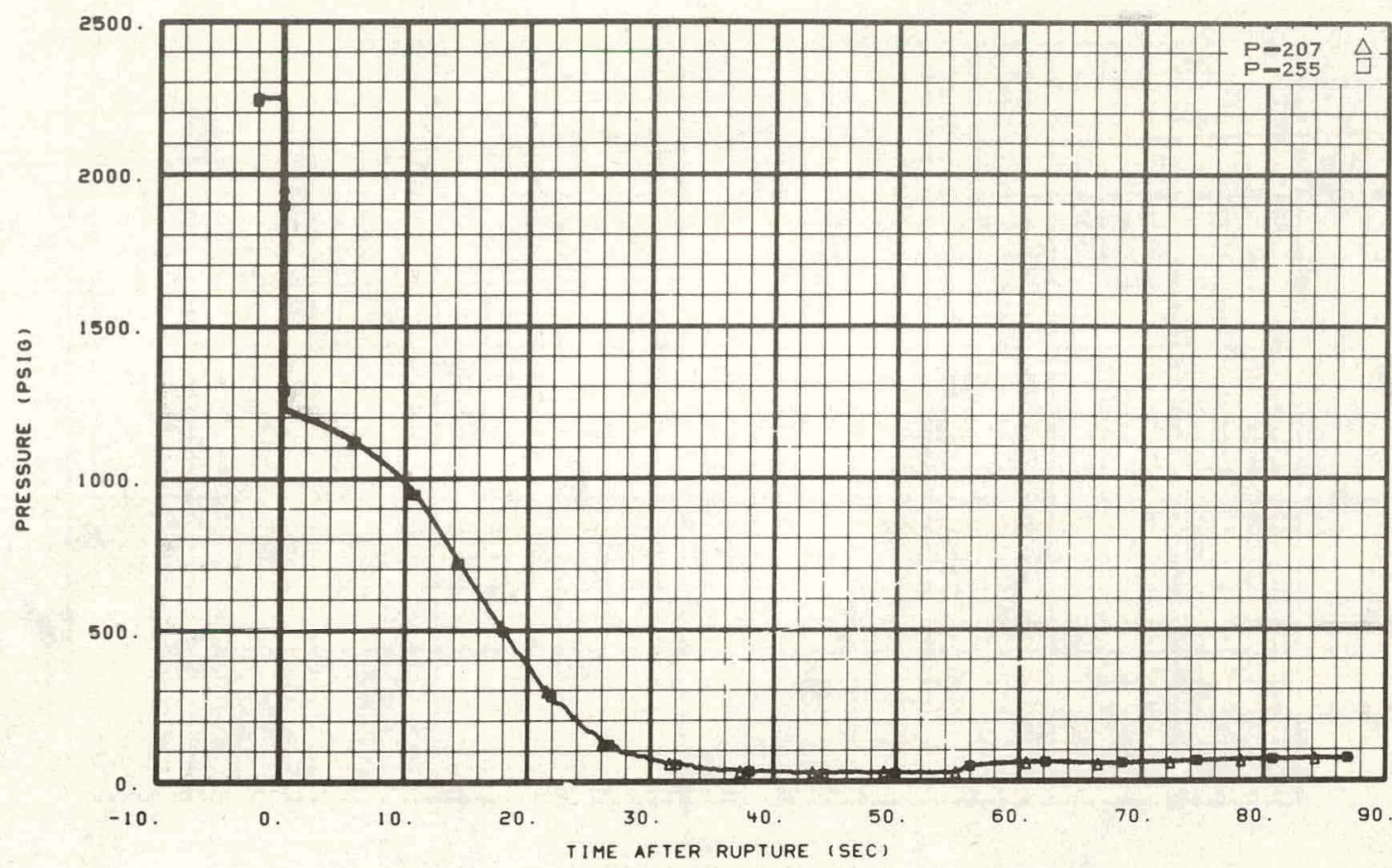

Fig. 43 Pressure in vesse1.

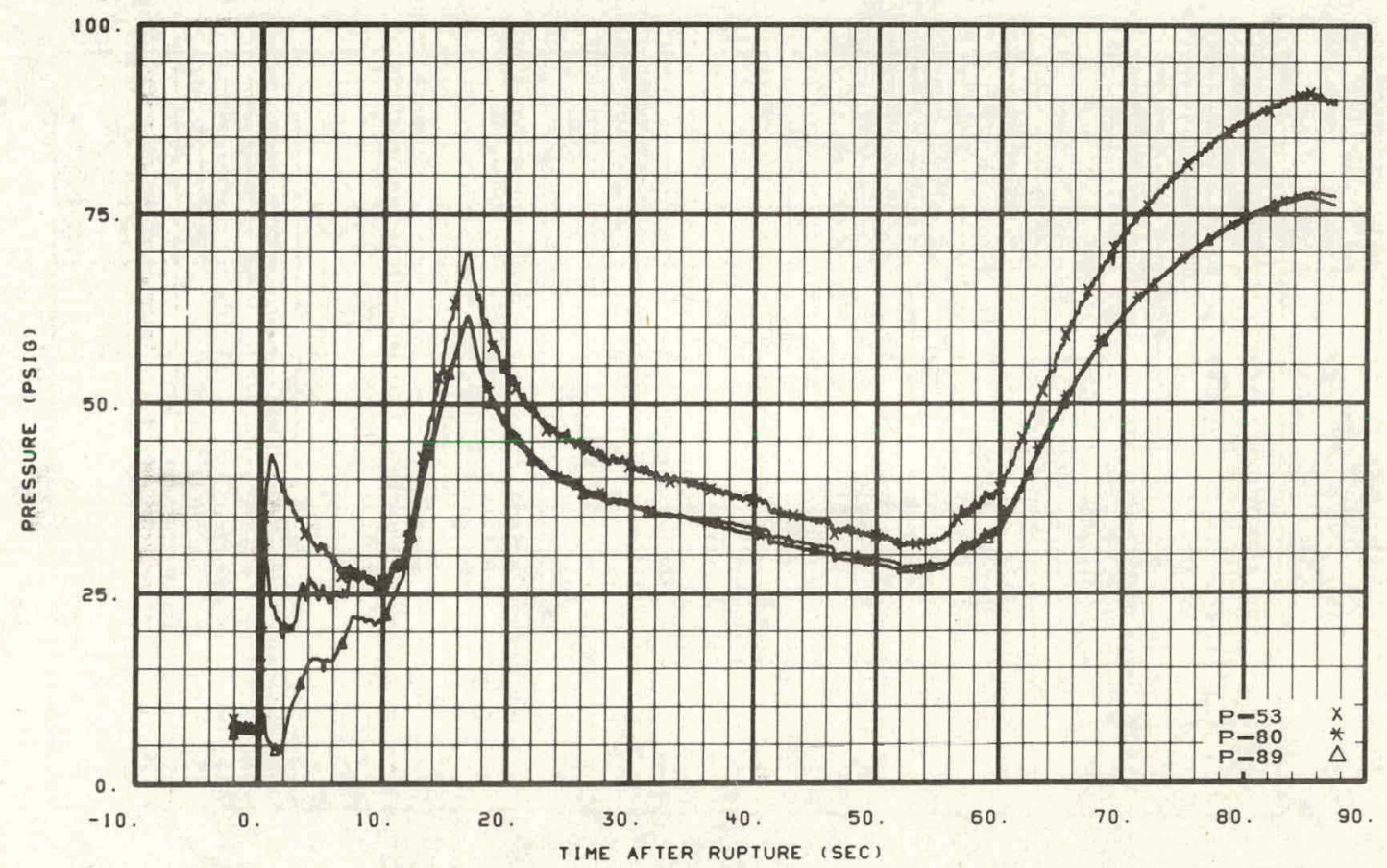

Eig. 44 Pressurc in pressure suppression system. 


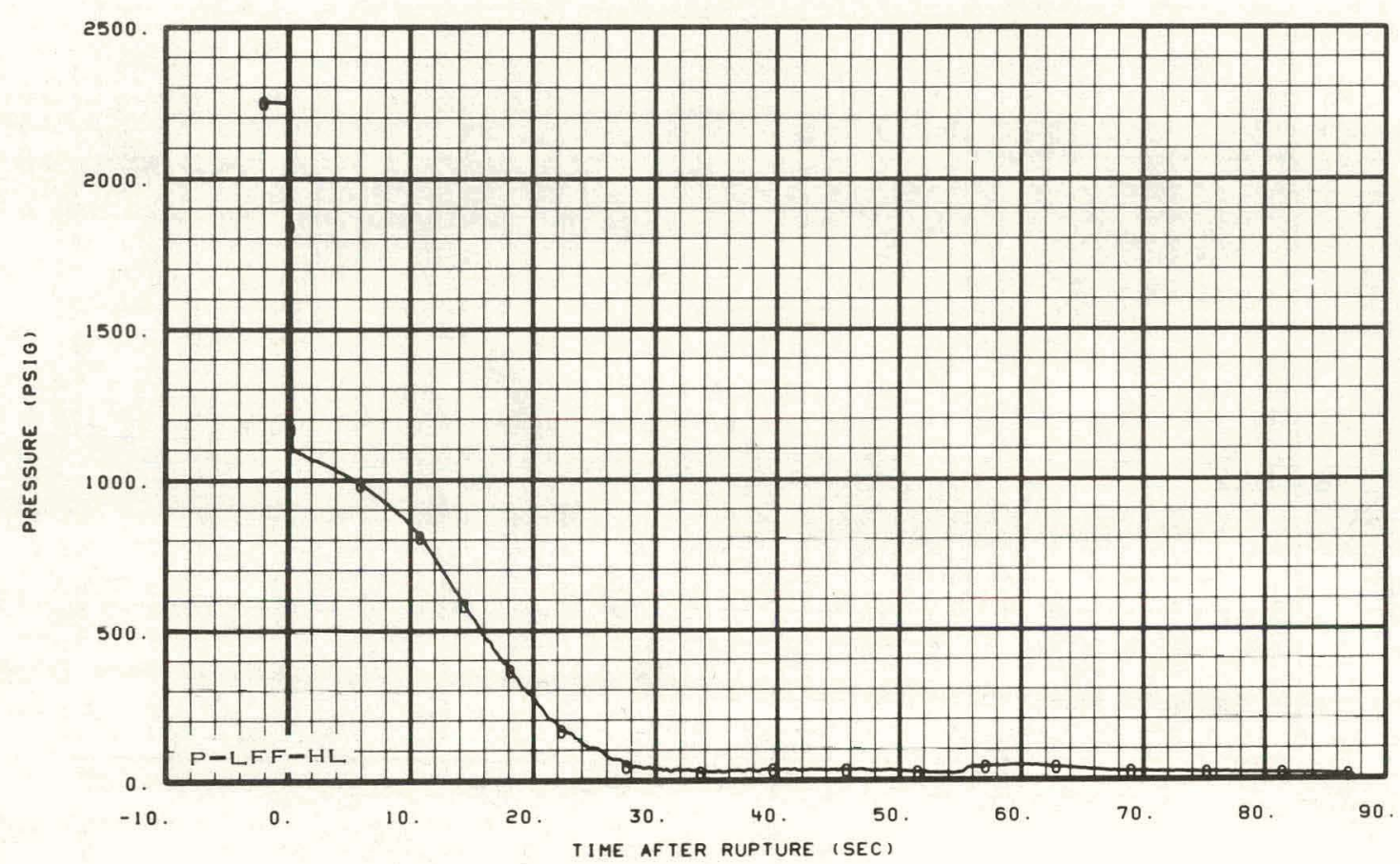

Fig. 45 Pressure at hot leg stub in upper plenum (LOFT free field pressure transducer).

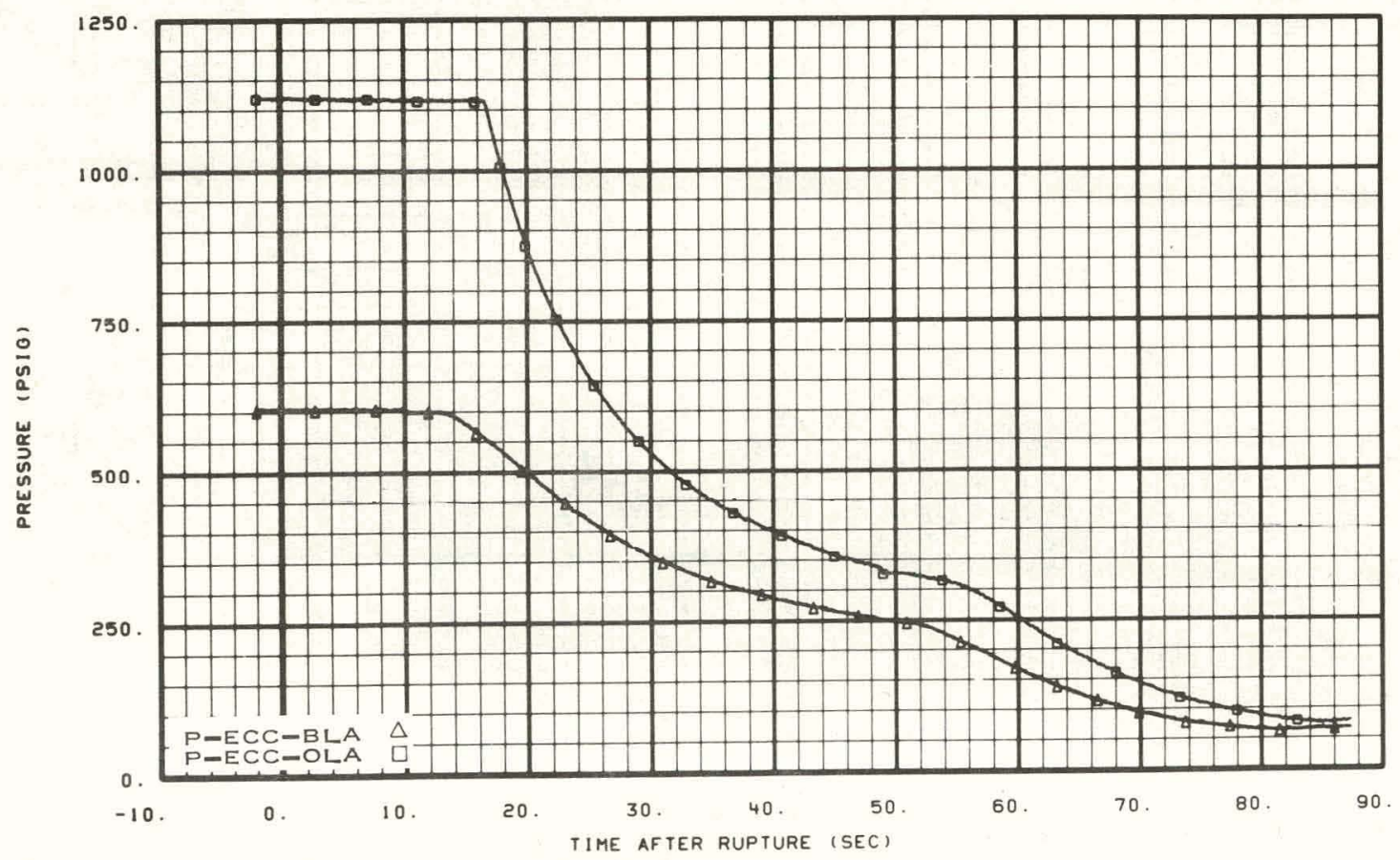

Fig. 46 Pressure of ECC in accumulators. 


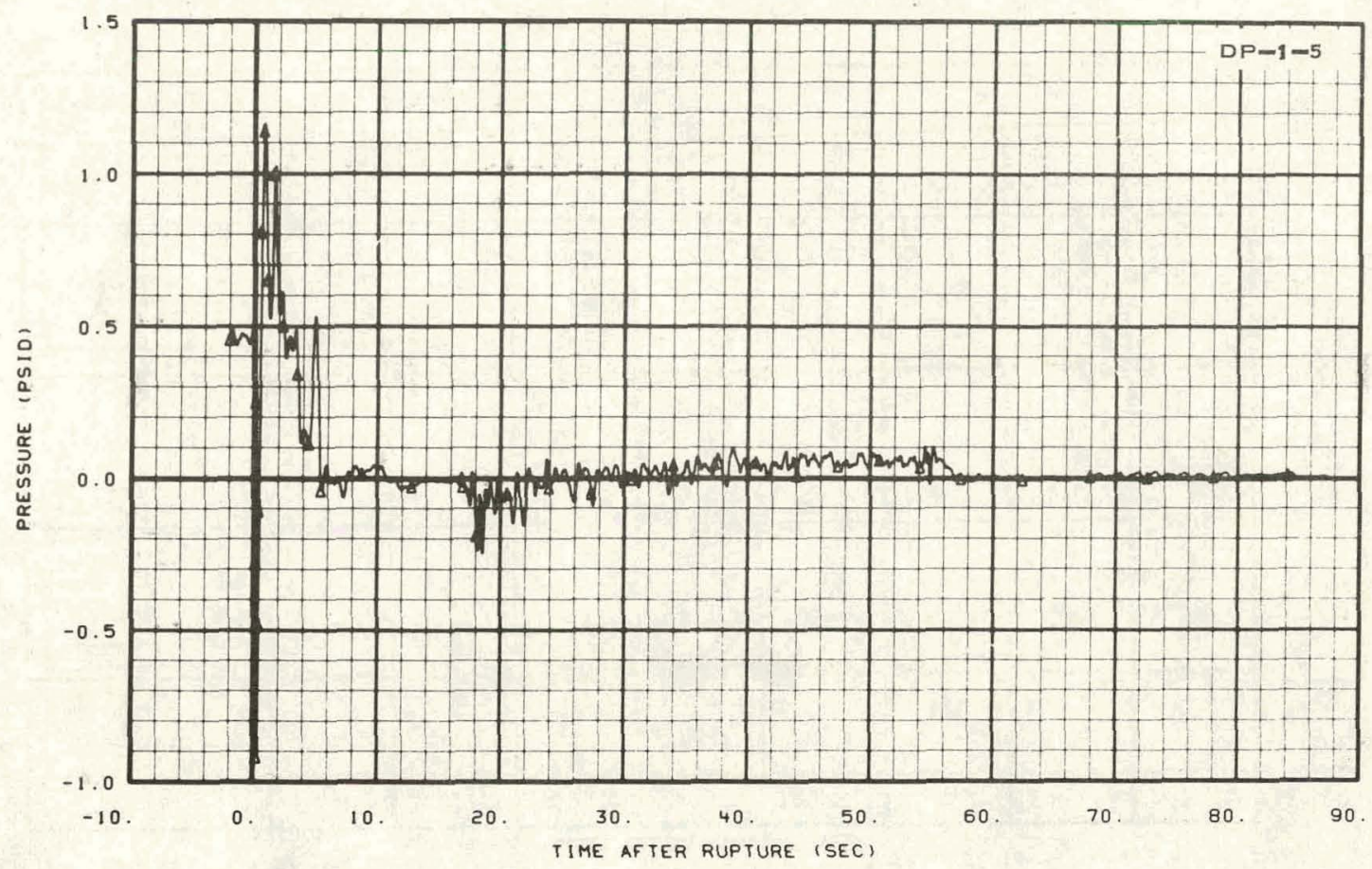

Fig. 47 Differential pressure, operating loop hot leg (DP-1-5).

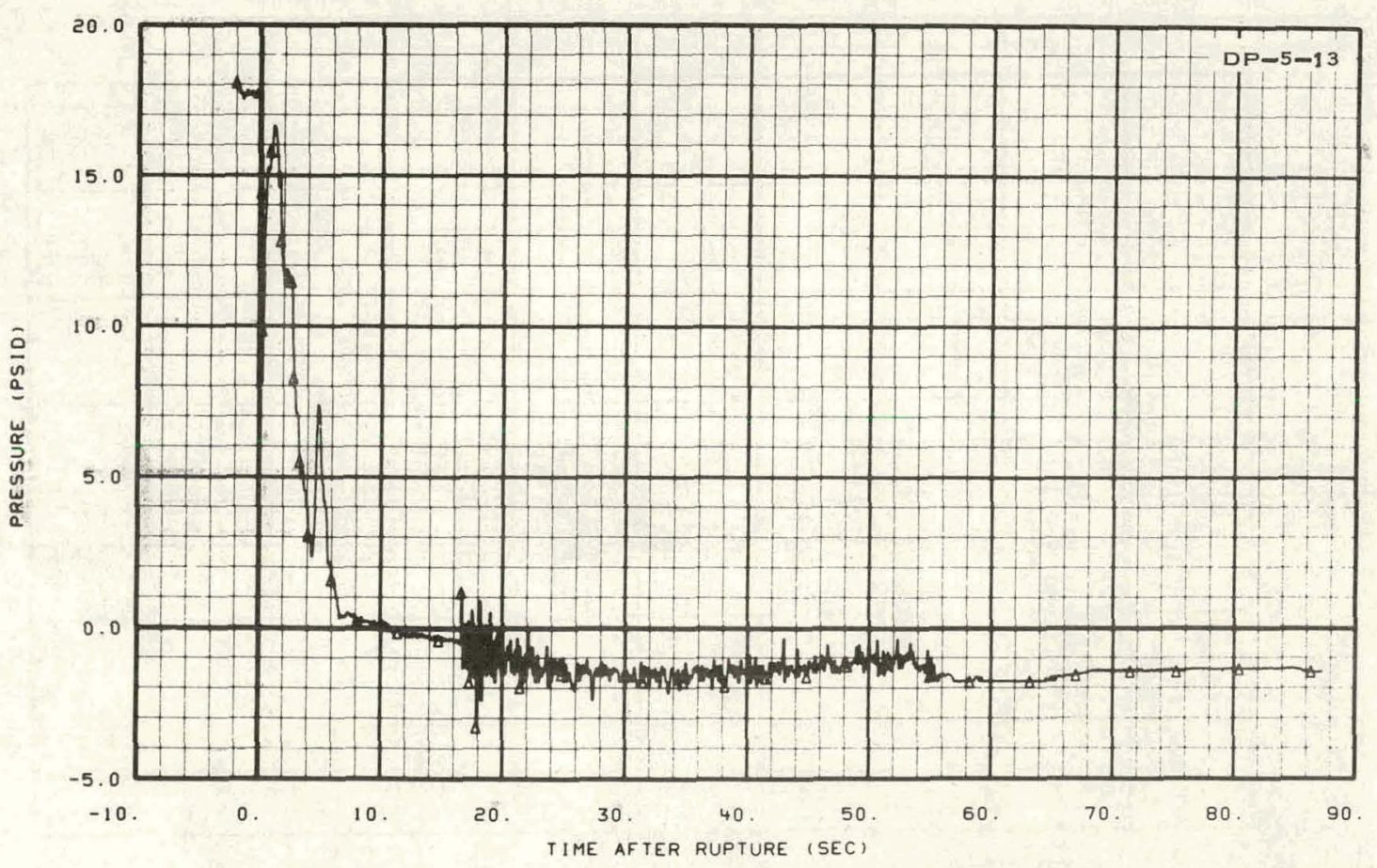

Tig. 48 Differential pressure across steam generator (DP-5-13). 


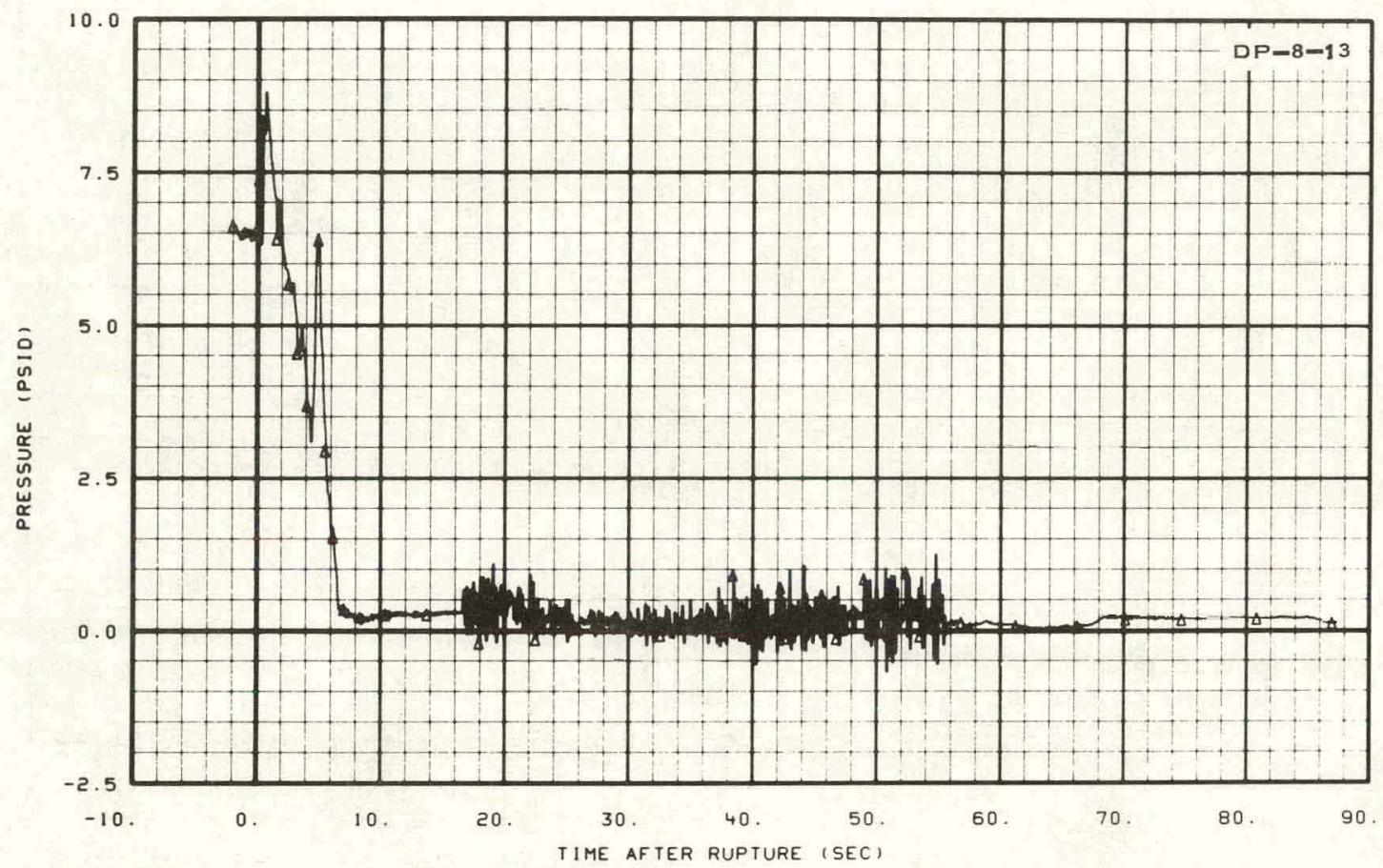

Fig. 49 Differential pressure across pump suction orifice (DP-8-13).

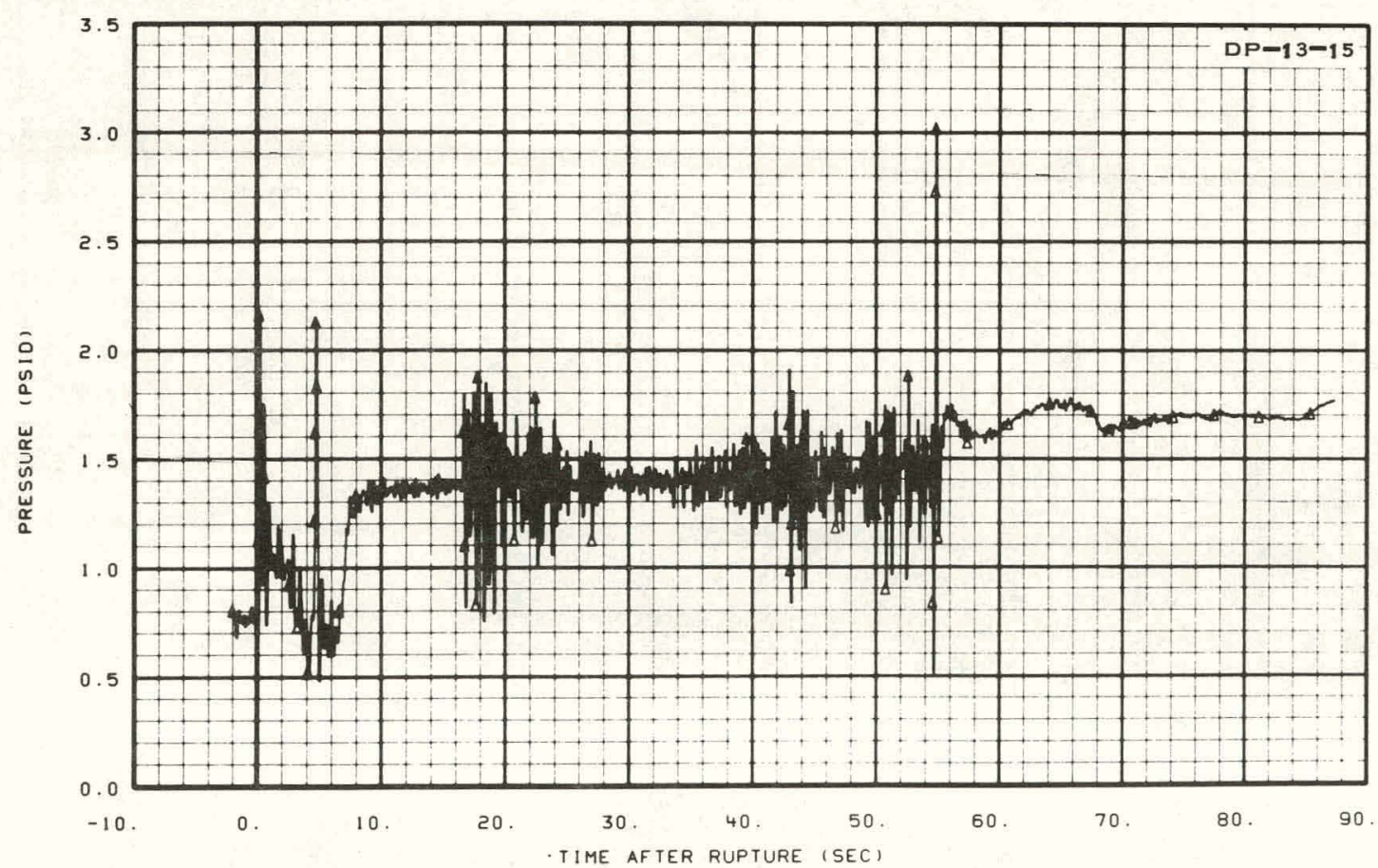

Fig. 50 Differential pressure across operating loop pump inlet (DP-13-15). 


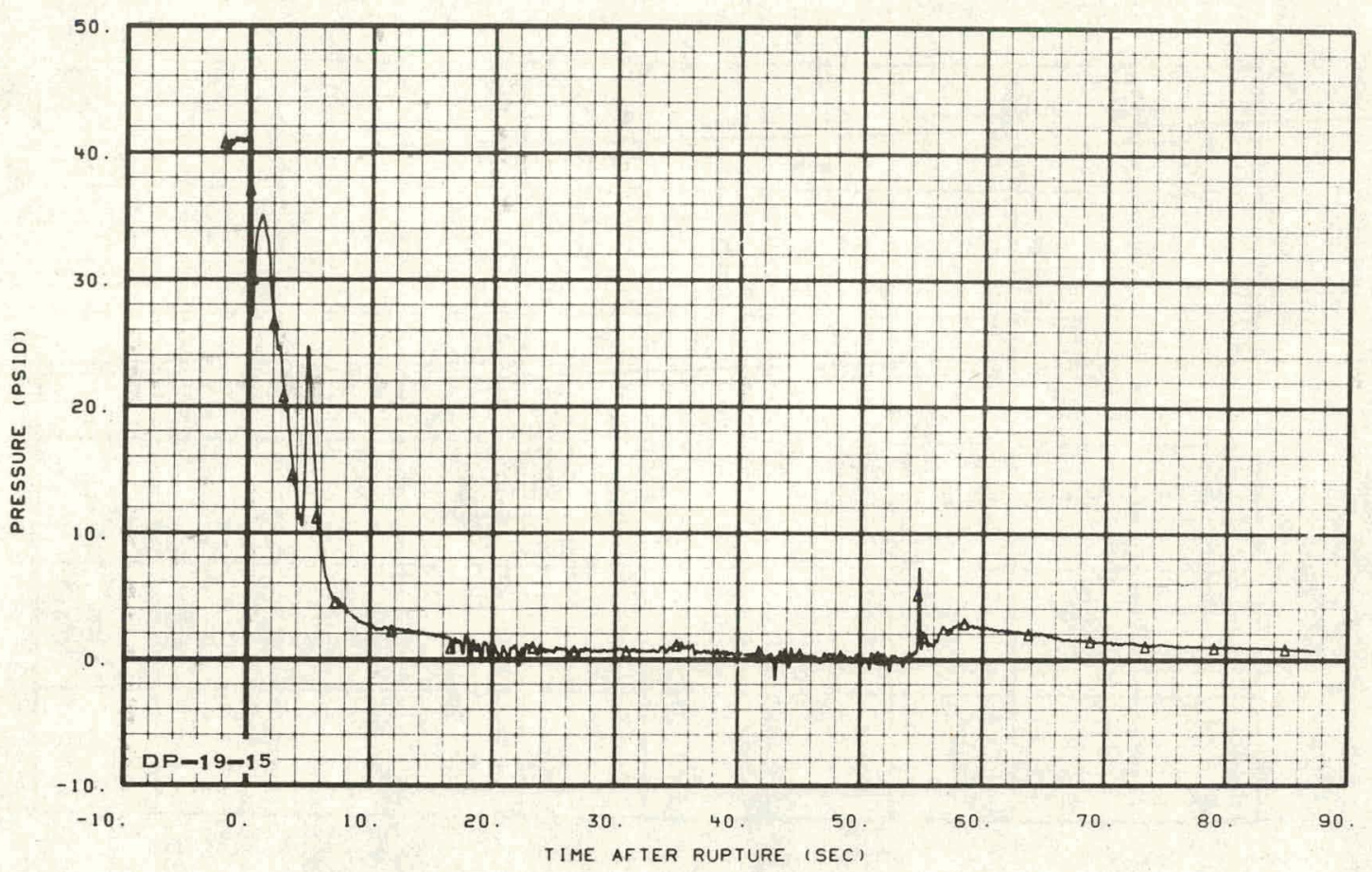

Fig. 51 Differential pressure across operating loop pump (DP-19-15).

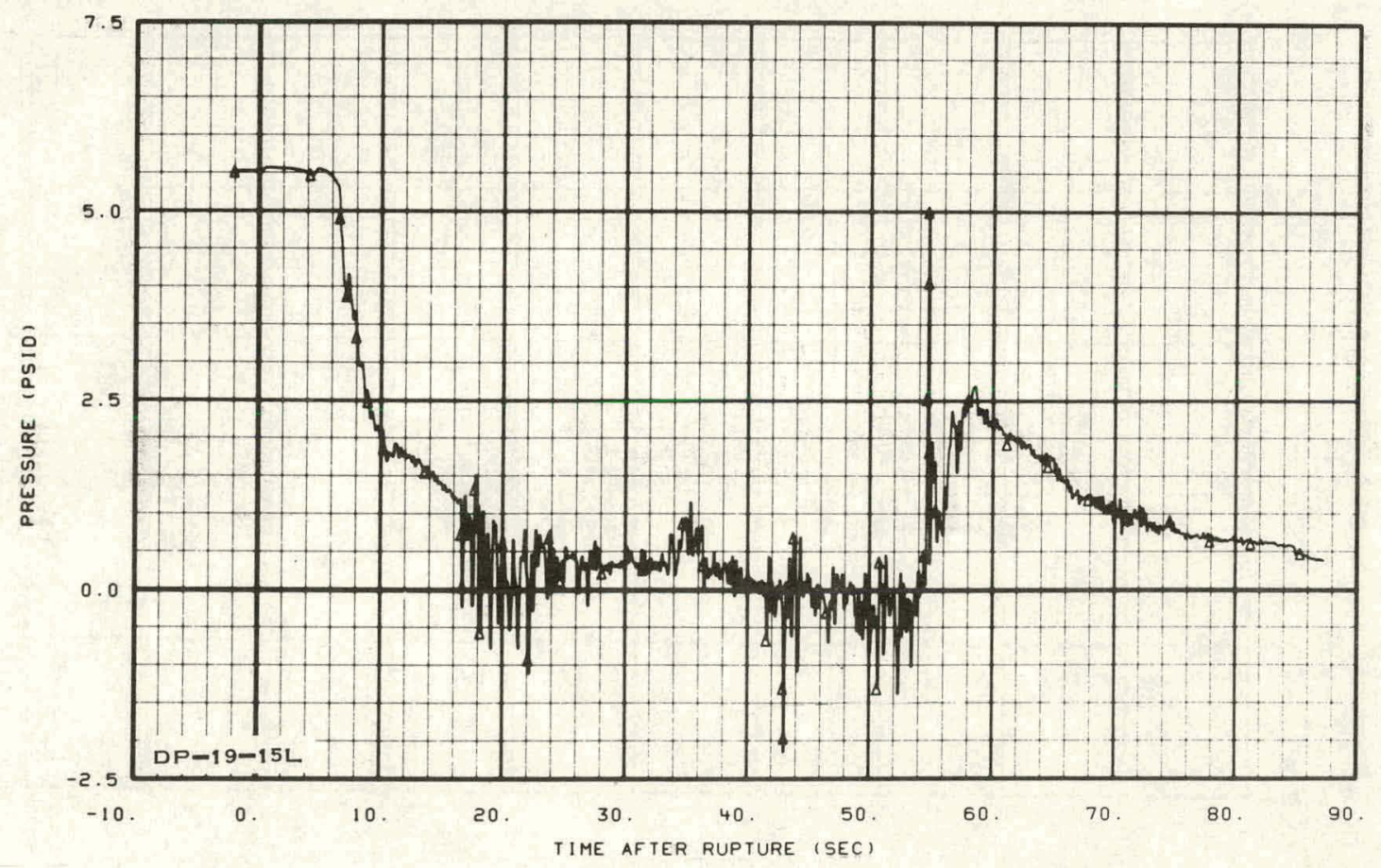

Fig. 52 Differential pressure across operating loop pump, low range (DP-19-15L) . 


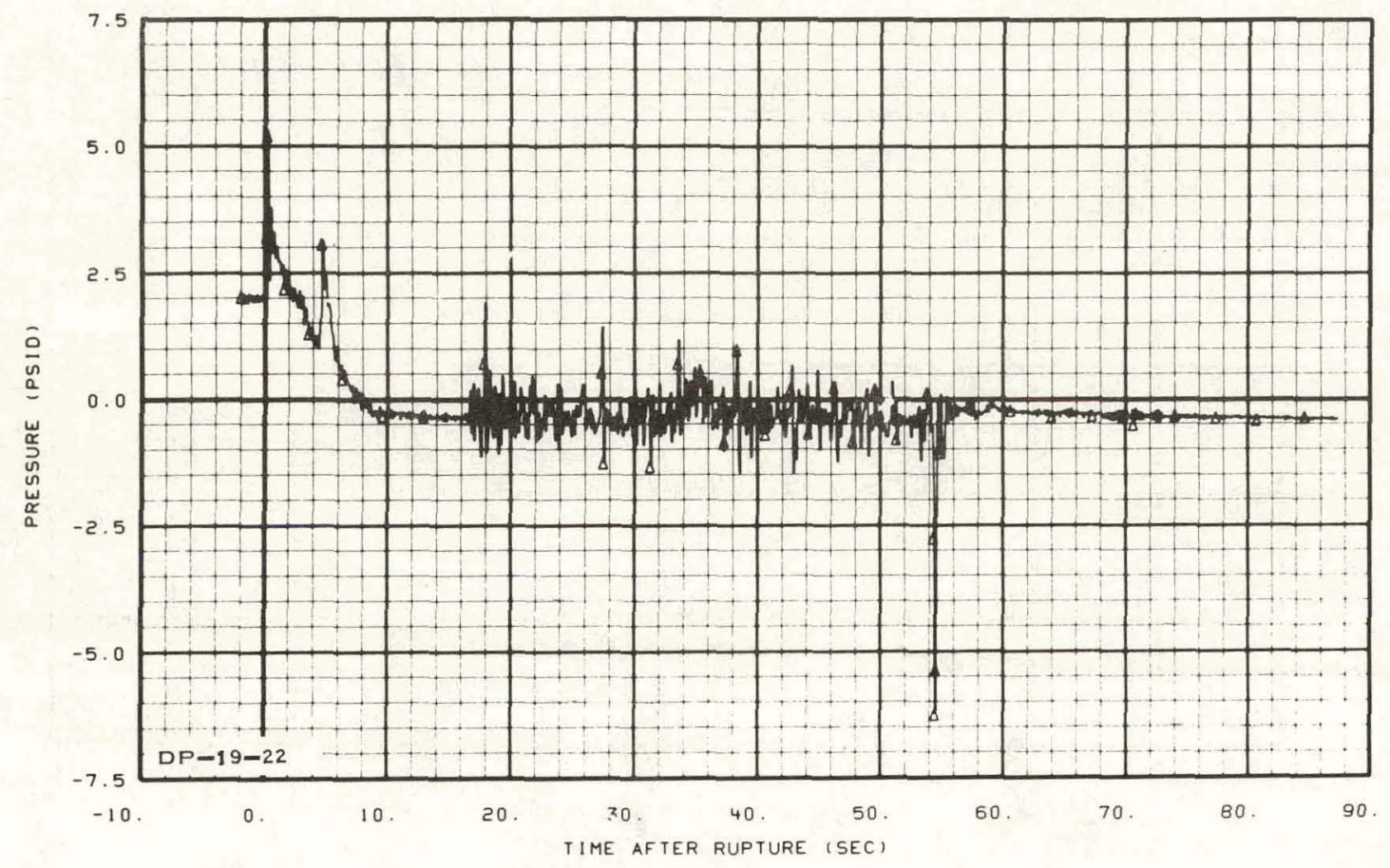

Fig. 53 Differential pressure across operating loop cold leg (DP-19-22).

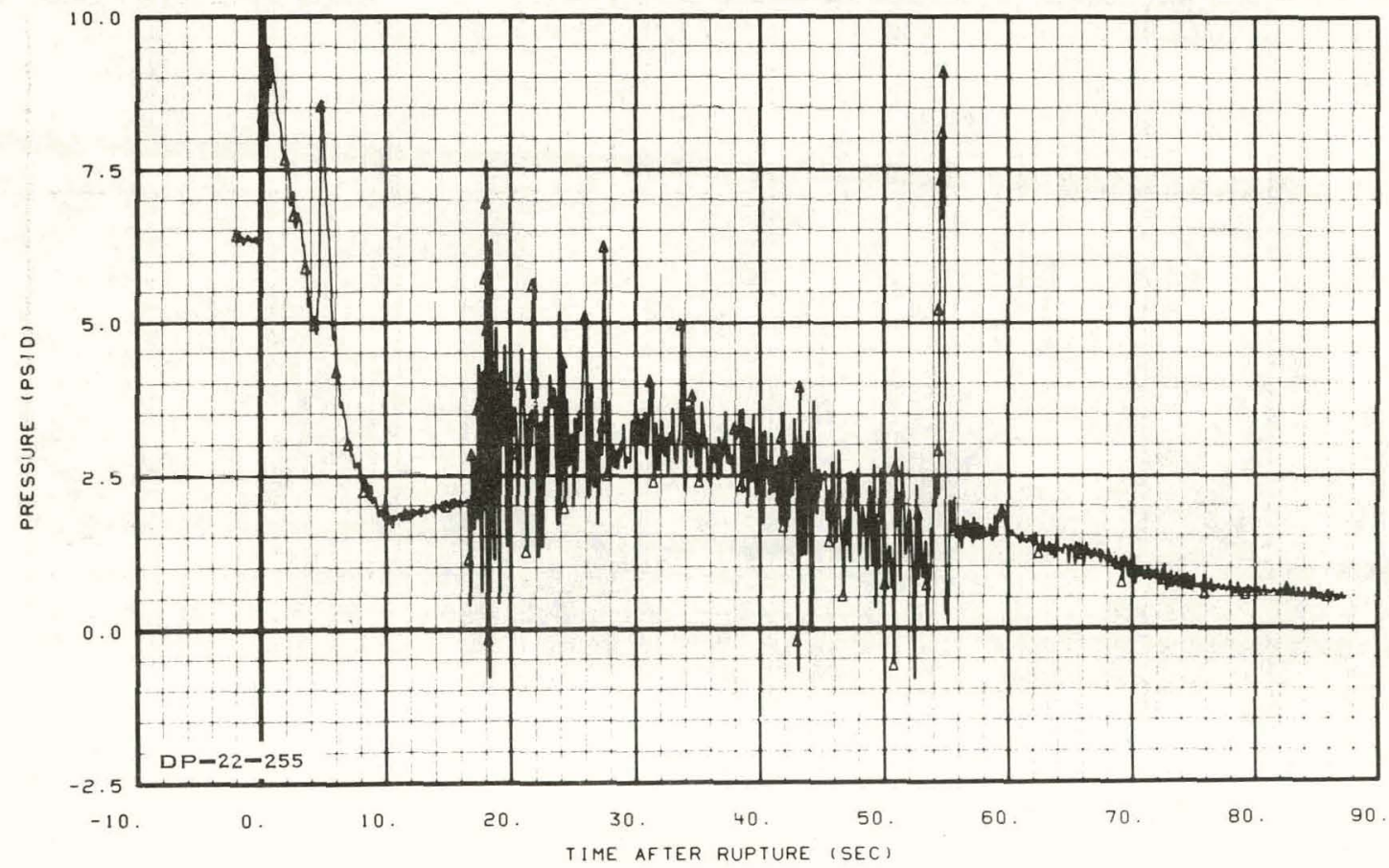

Fig. 54 Differential pressure between cold leg and lower plenum (DP-22-255). 


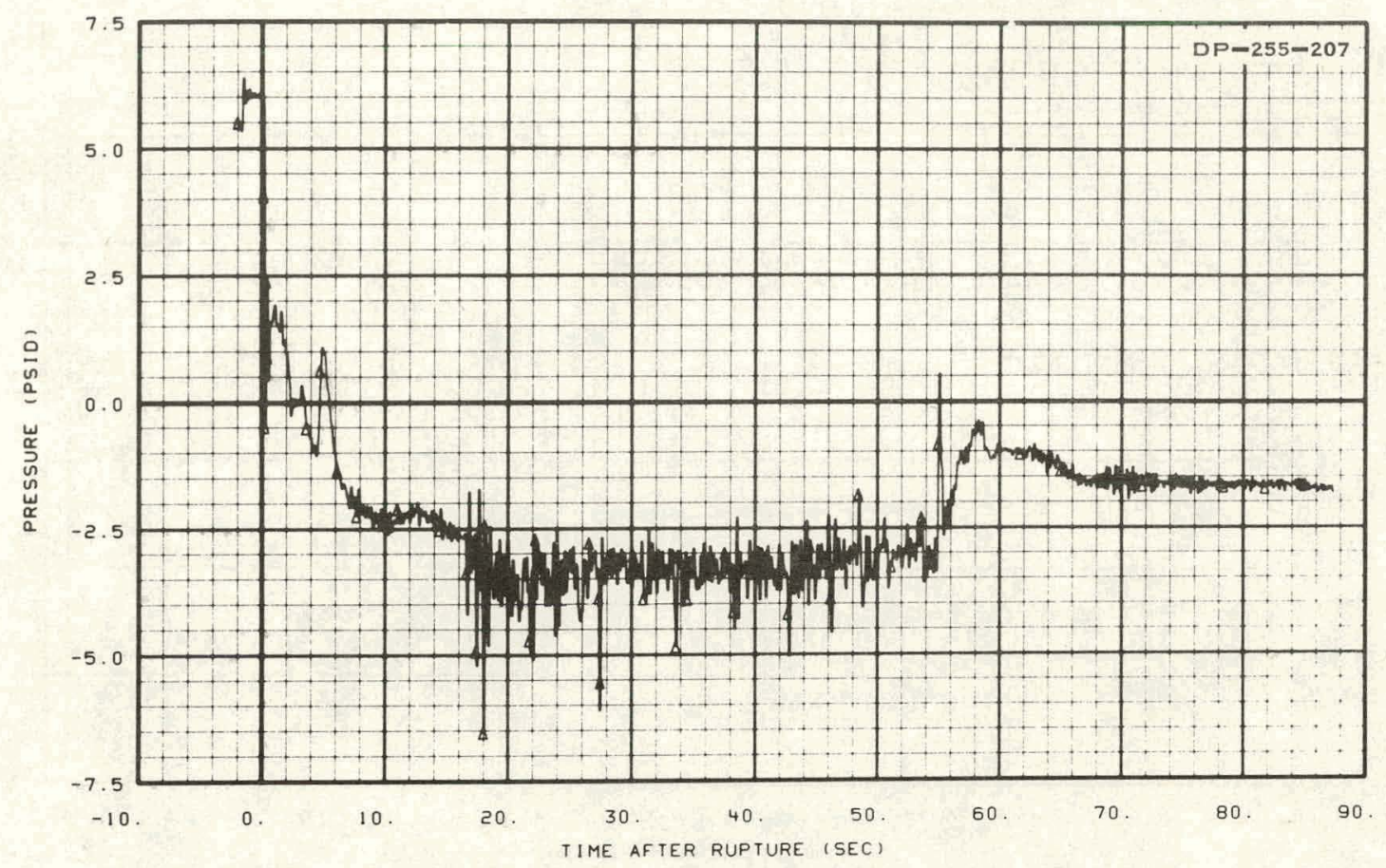

Fig. 55 Differential pressure across core (DP-255-267).

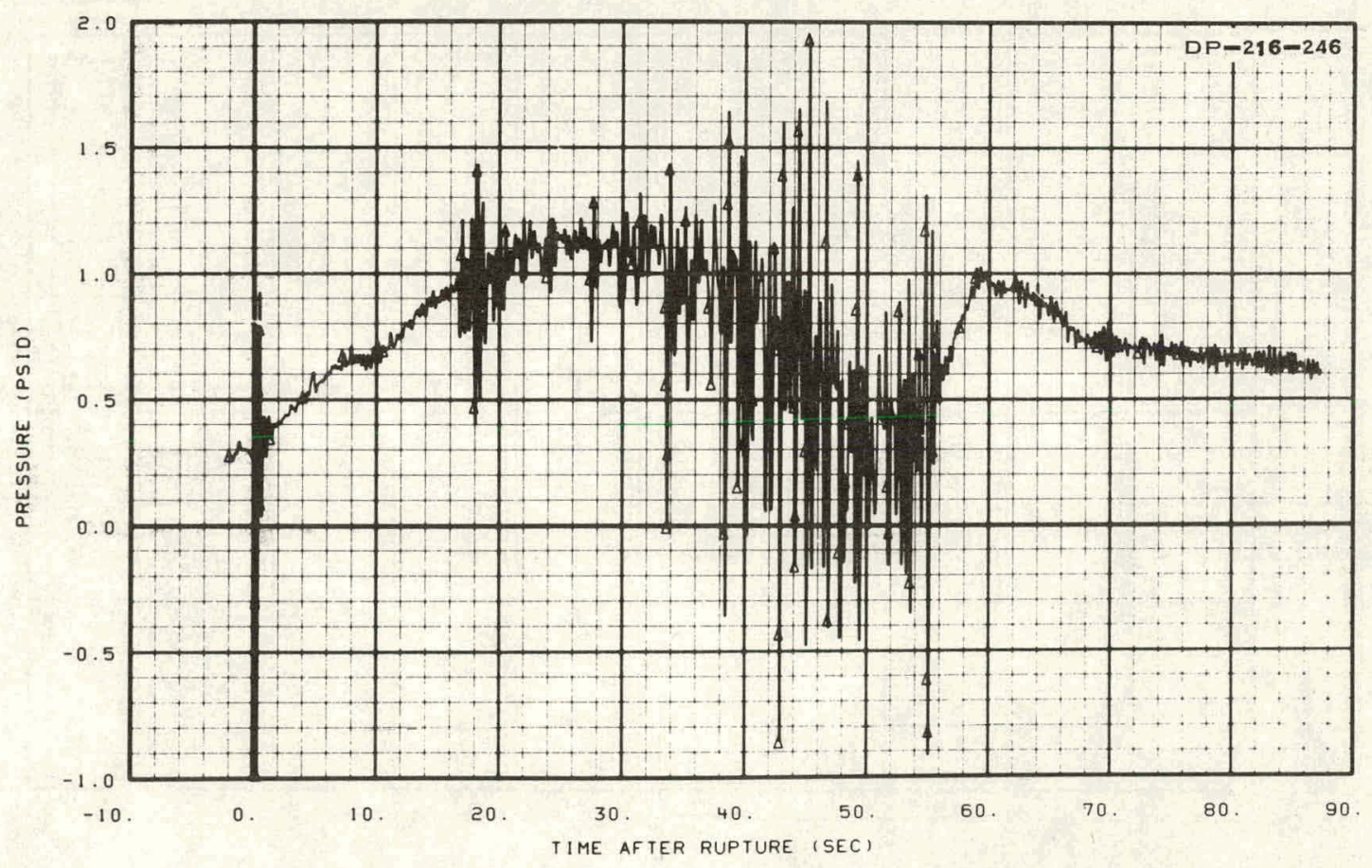

Fig. 56 Differential pressure across upper portion of downcomer $(\mathrm{DP}-216-246)$. 


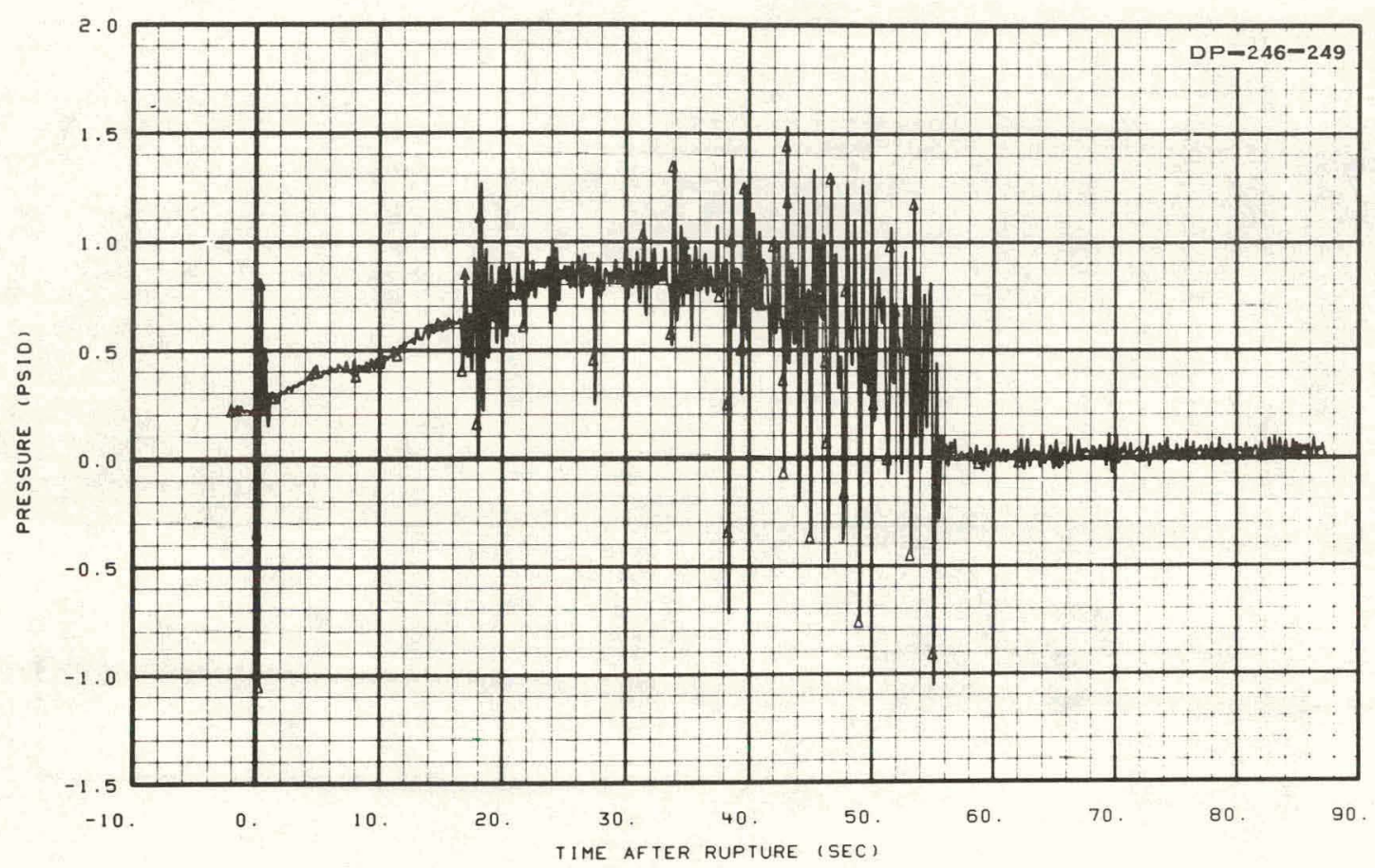

Fig. 57 Differential pressure across middle portion of downcomer (DP-246-249).

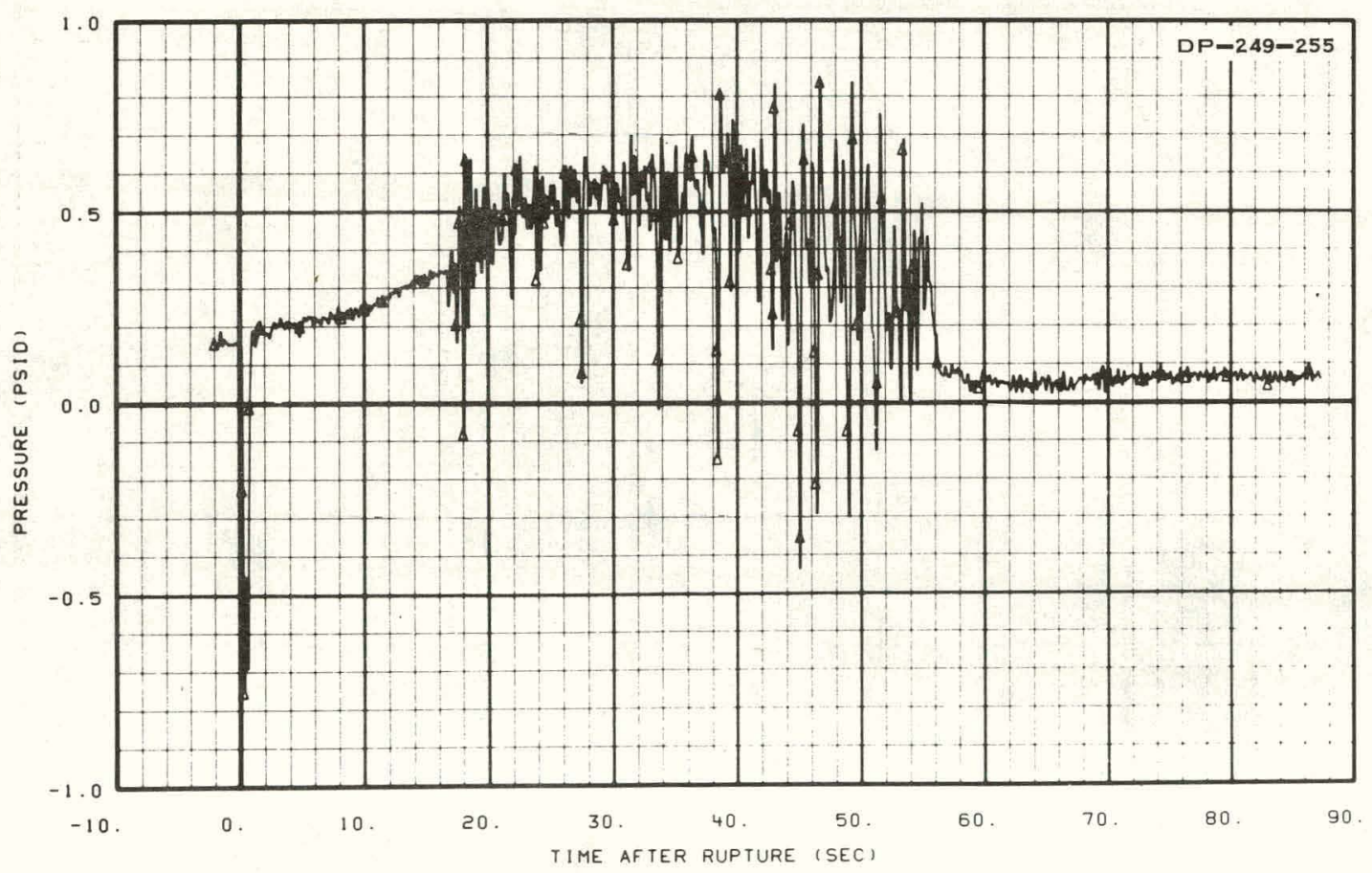

Fig. 58 Differential pressure across lower portion of downcomer (DP-249-255). 


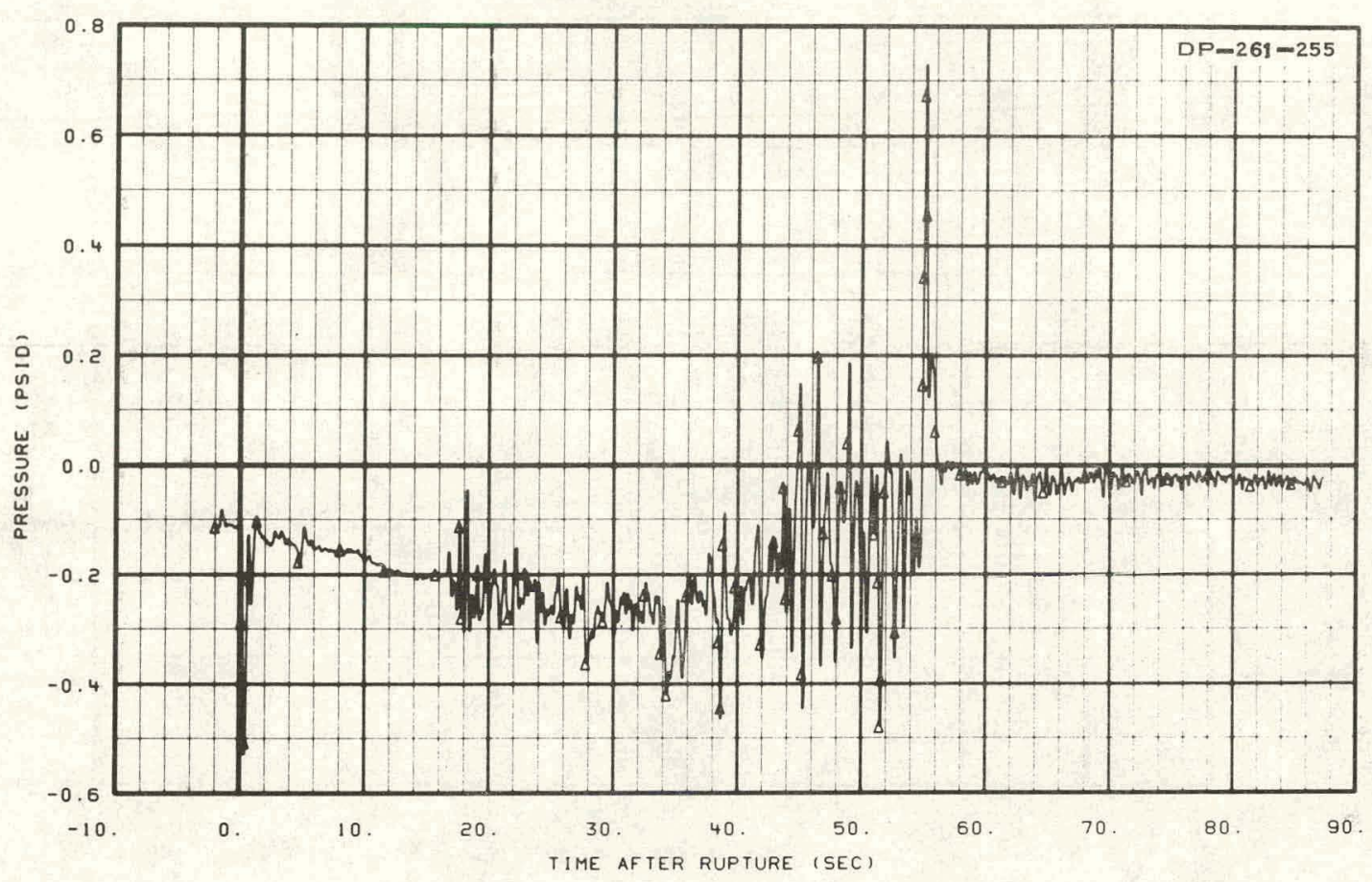

Fig. 59 Differential pressure across lower plenum (DP-261-255).

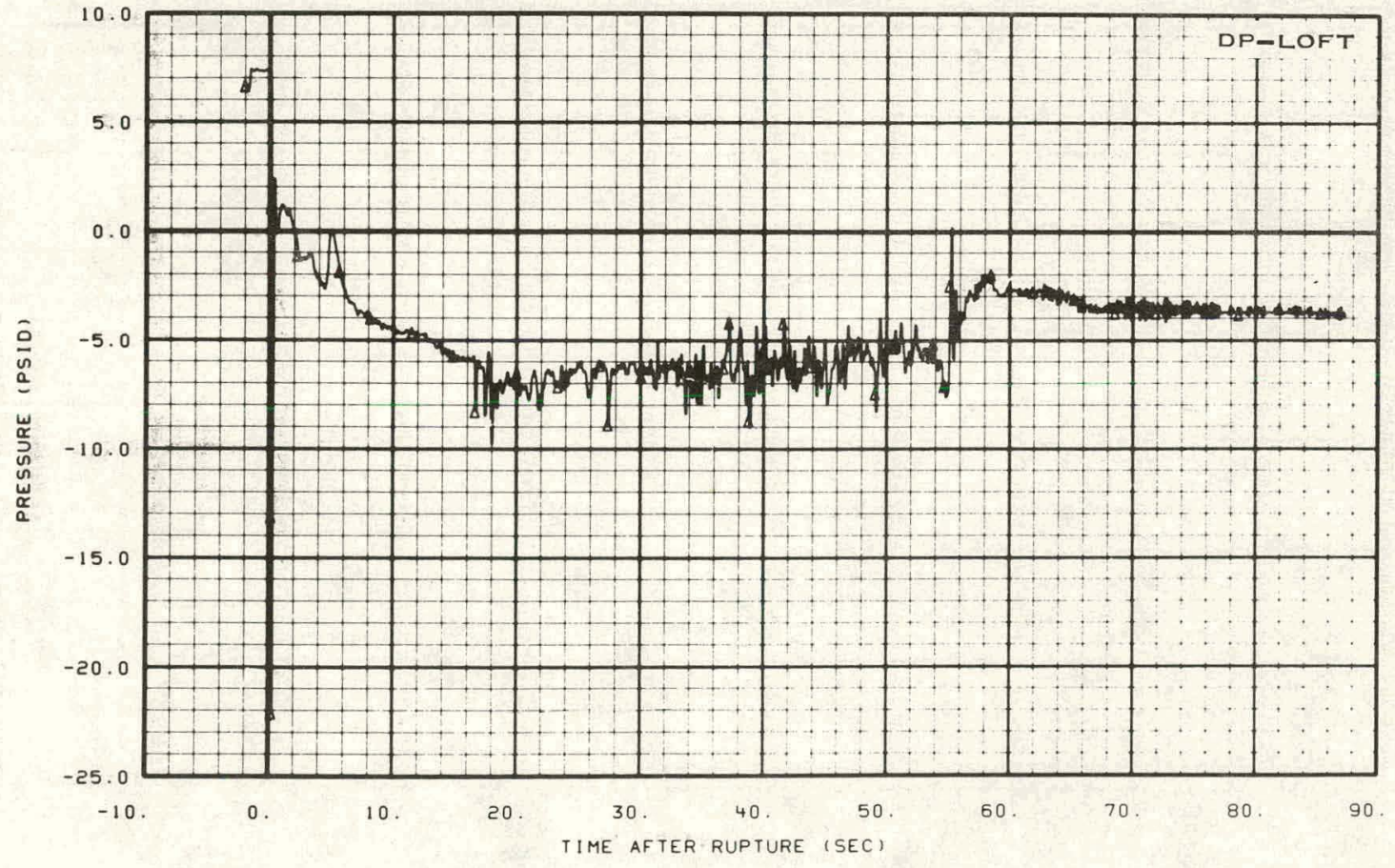

Fig. 60 Differential pressure across vessel (DP-LOFT). 


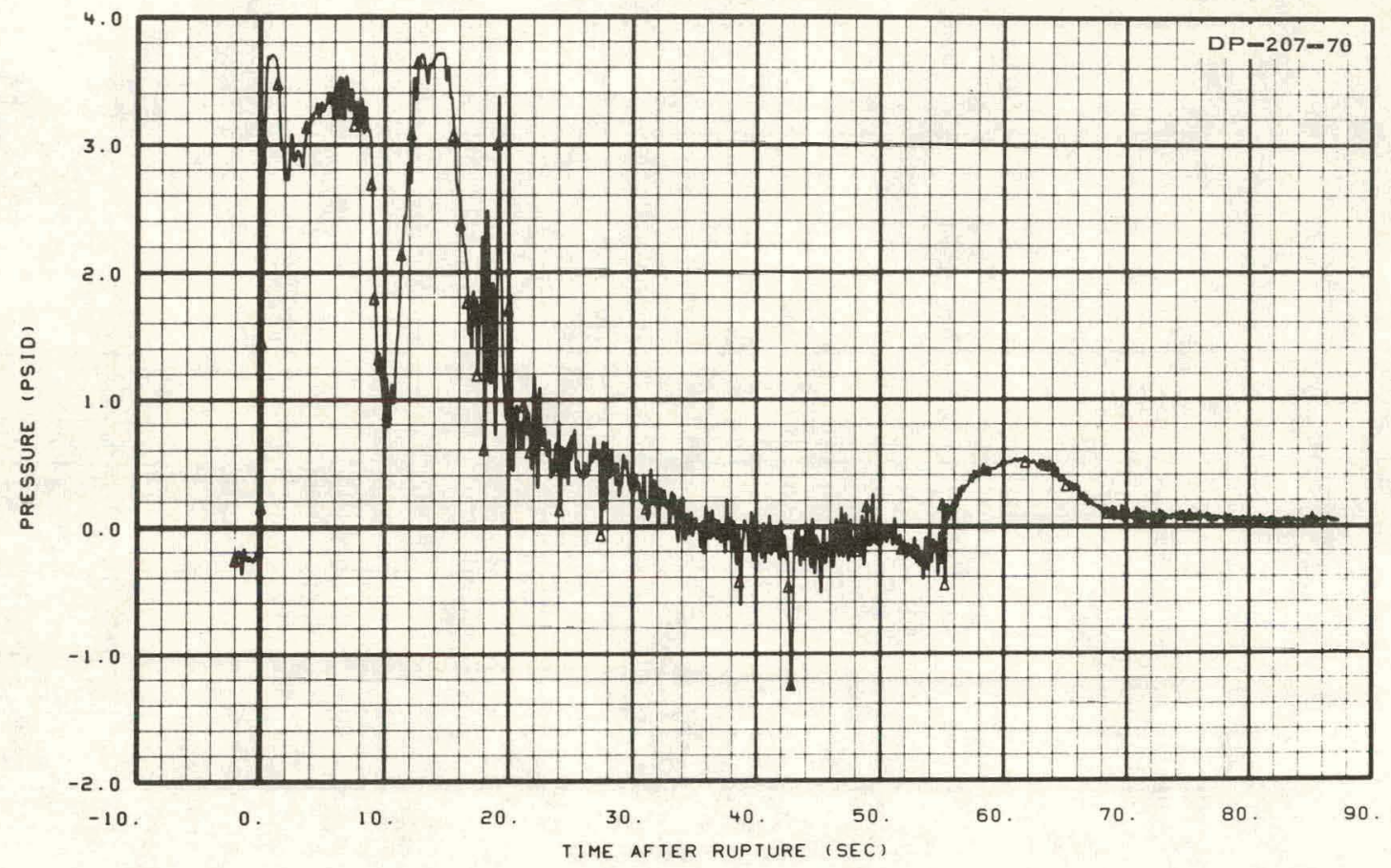

Fig. 61 Differential pressure between vessel upper plenum and blowdown loop hot leg (DP-207-70).

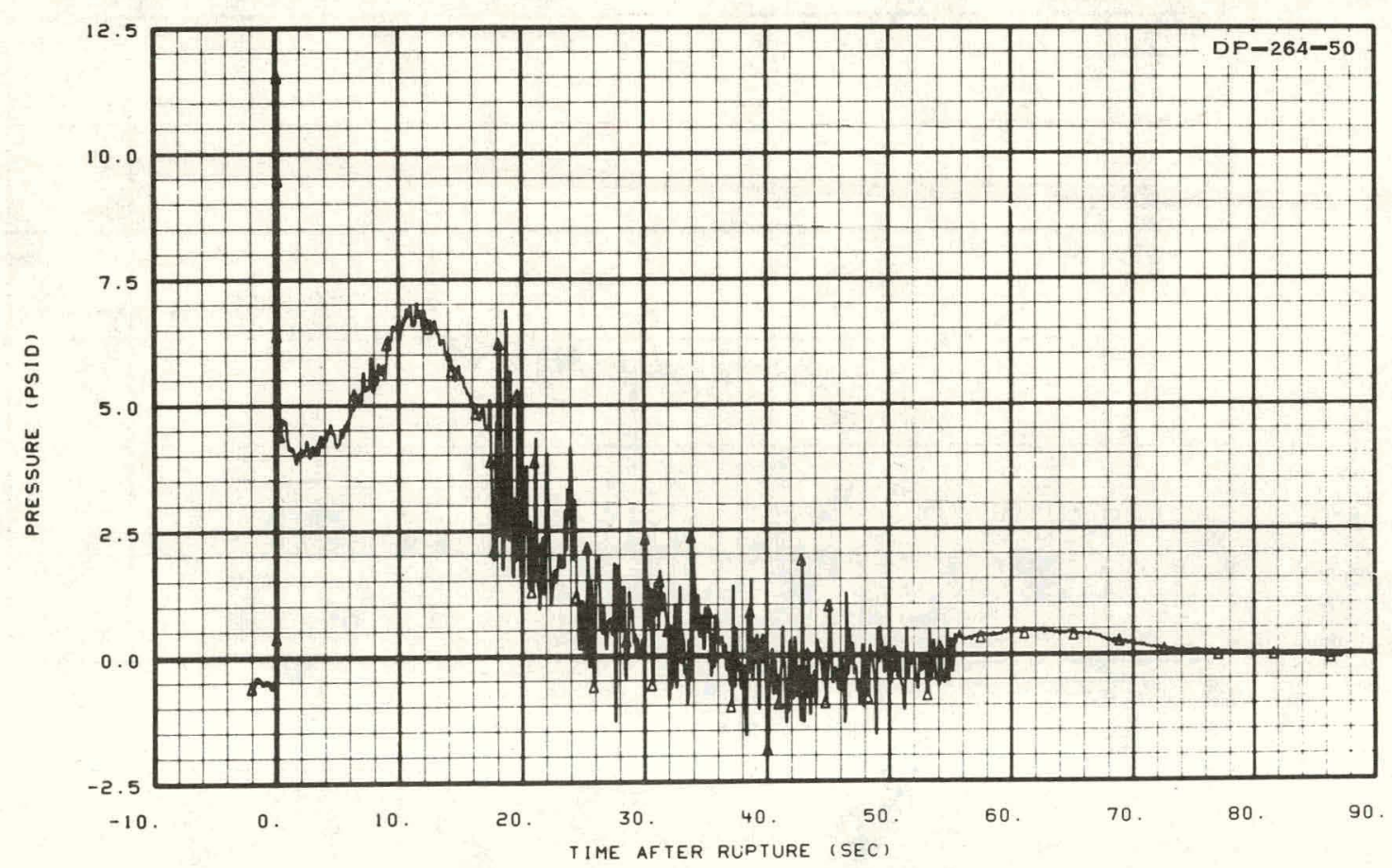

Fig. 62 Differential pressure between vessel inlet annulus and blowdown loop cold leg (DP-264-50). 


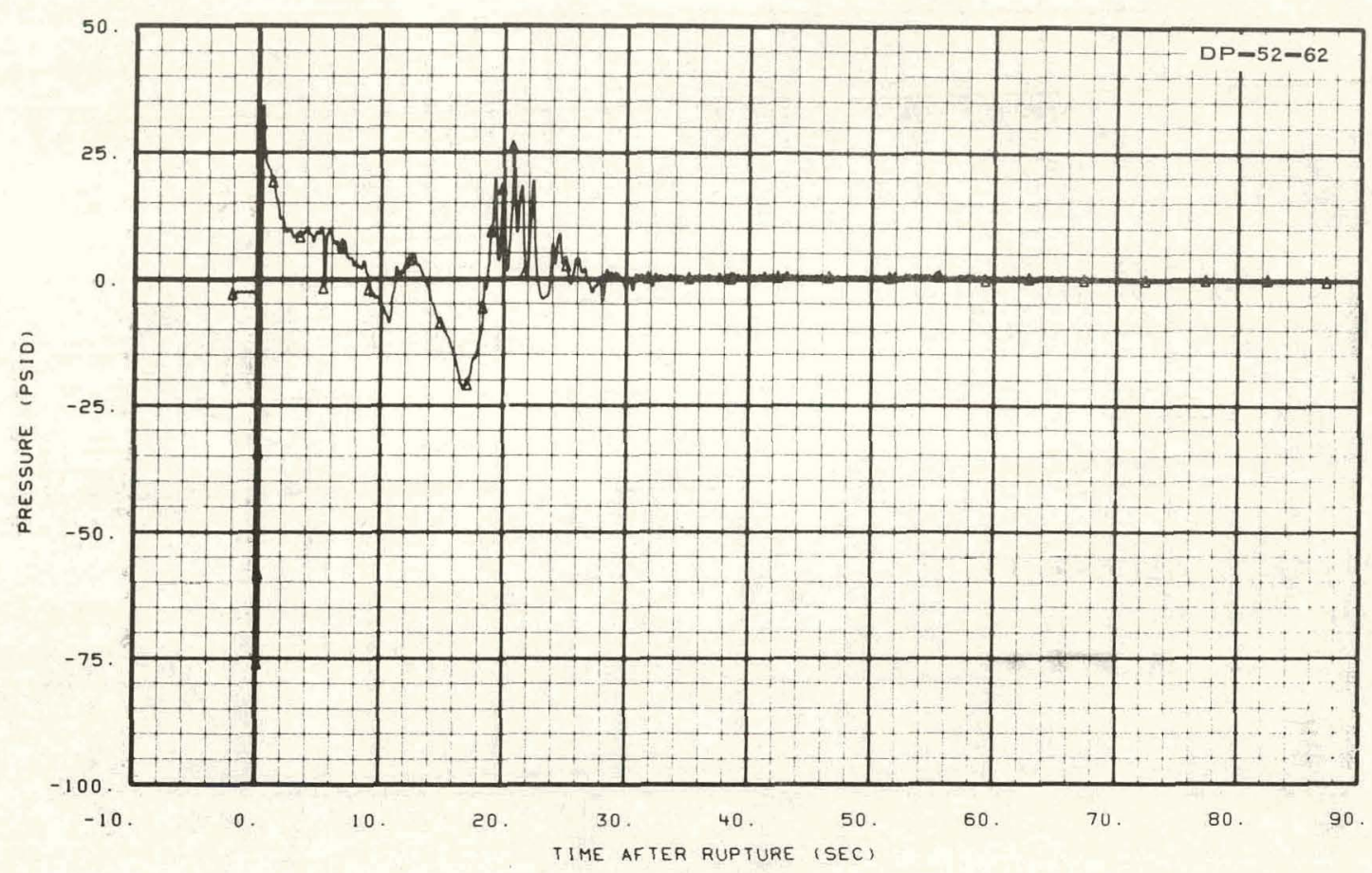

Fig. 63 Differential pressure between inner disc cavities (DP-52-62).

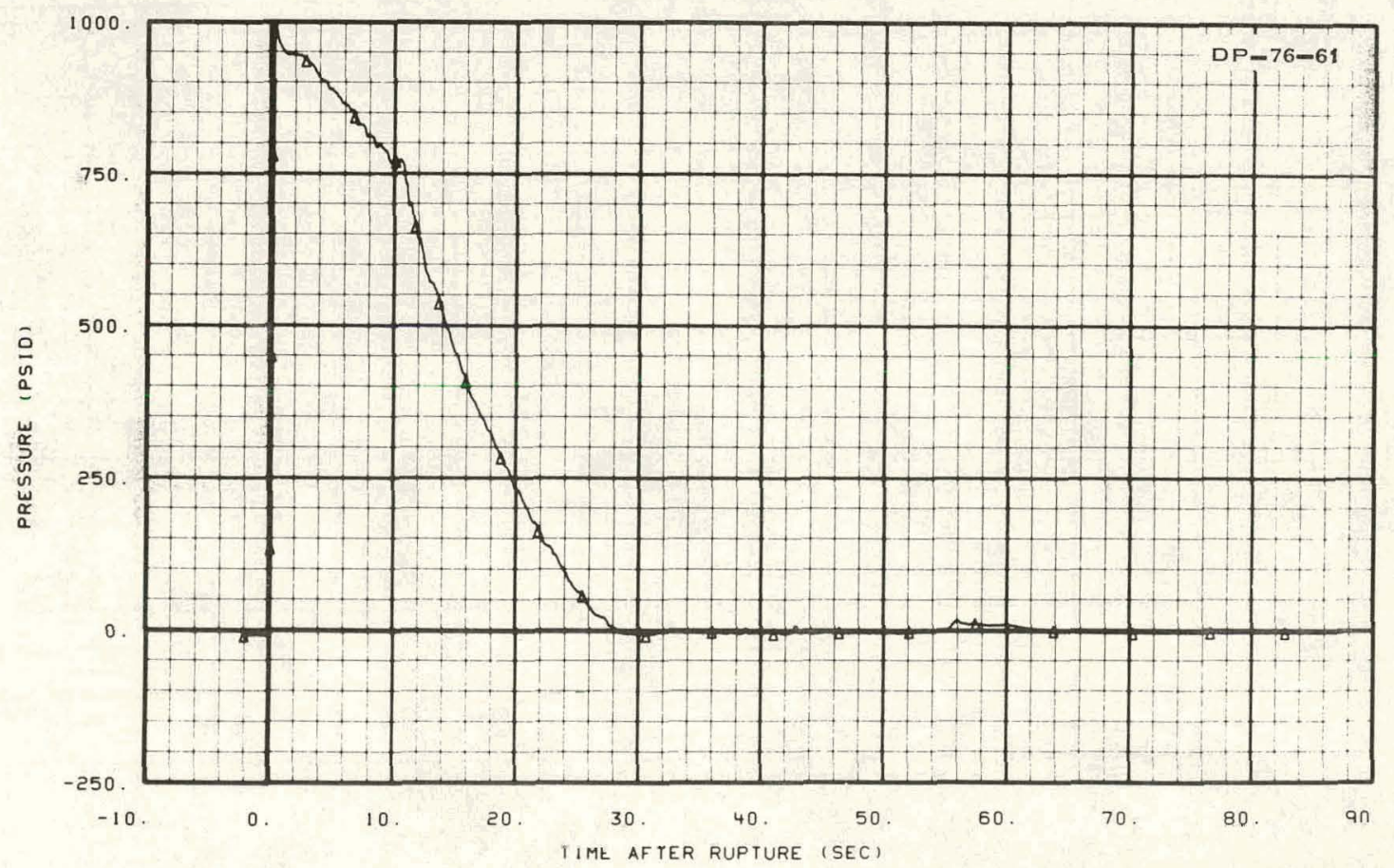

Fig. 64 Differential pressure across blowdown loop hot leg nozzle (DP-76-61). 


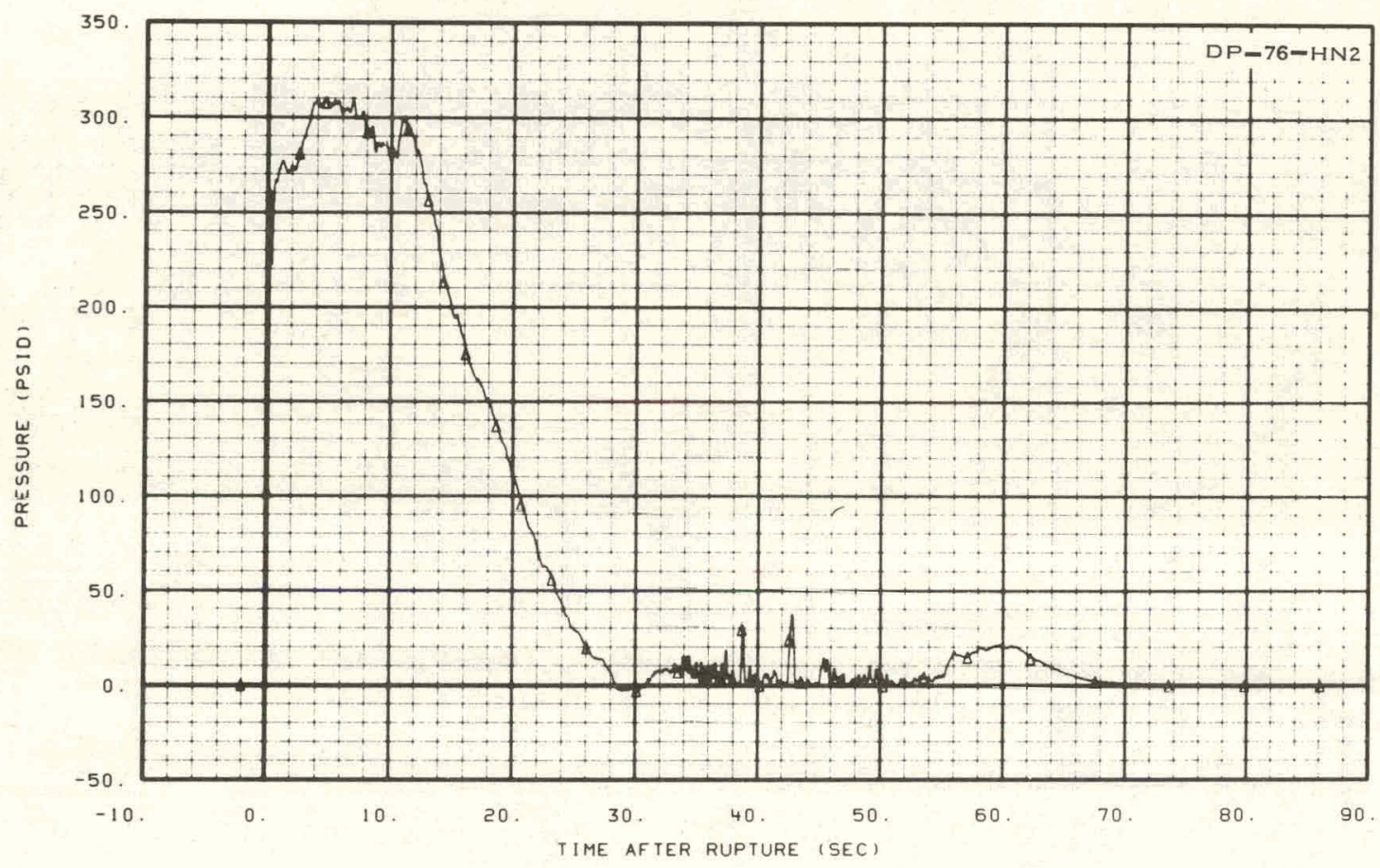

Fig. 65 Differential pressure between simulated pump and throat of blowdown loop hot leg nozzle (DP-76-HN2).

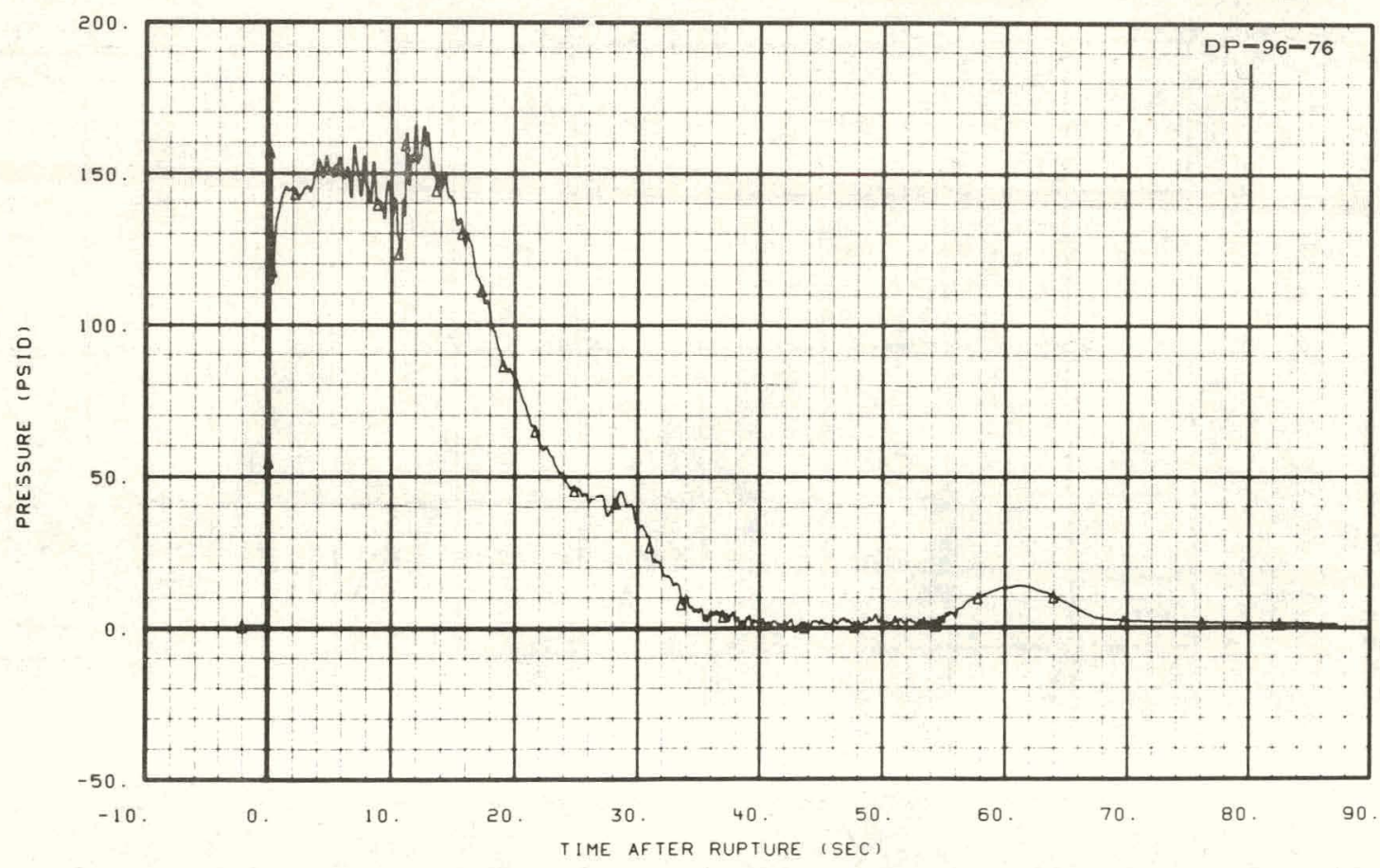

Fig. 66 Differential pressure across simulated pump (DP-96-76). 


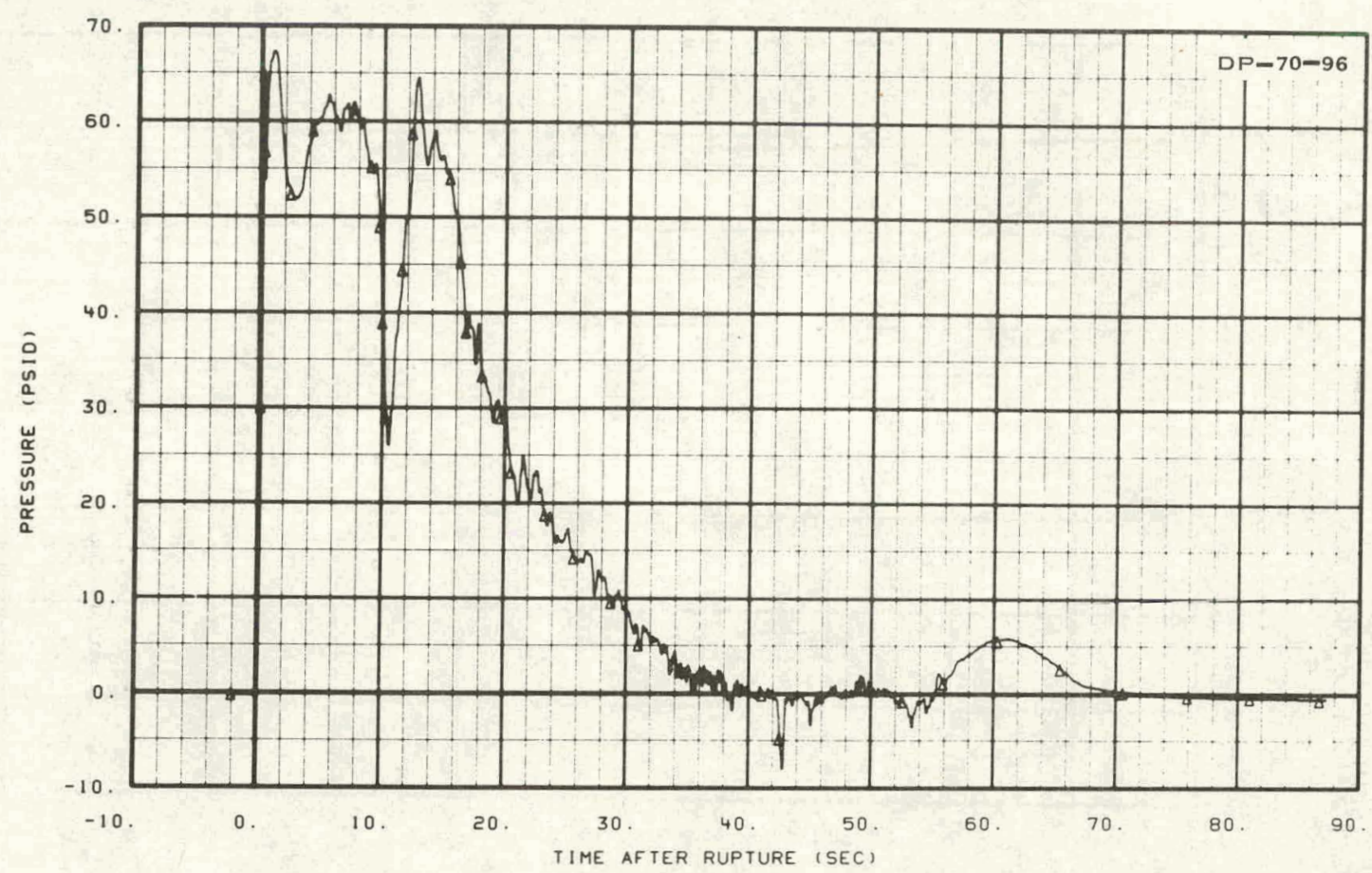

Fig. 67 Differential pressure across simulated steam generator (DP-70-96).

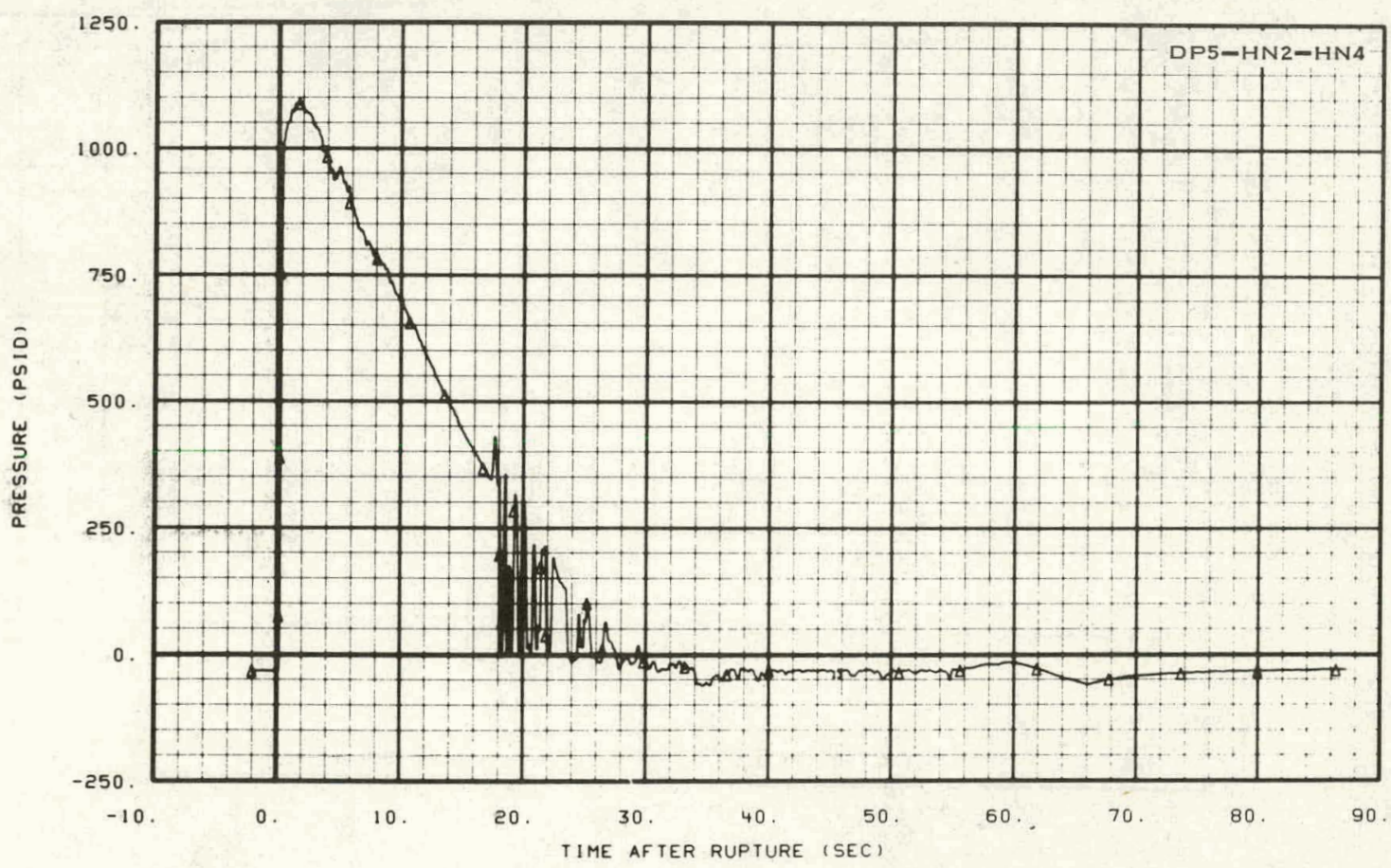

Fig. 68 Differential pressure across blowdown loop cold leg nozzle diverging section (DP5-HN2-HN4). 


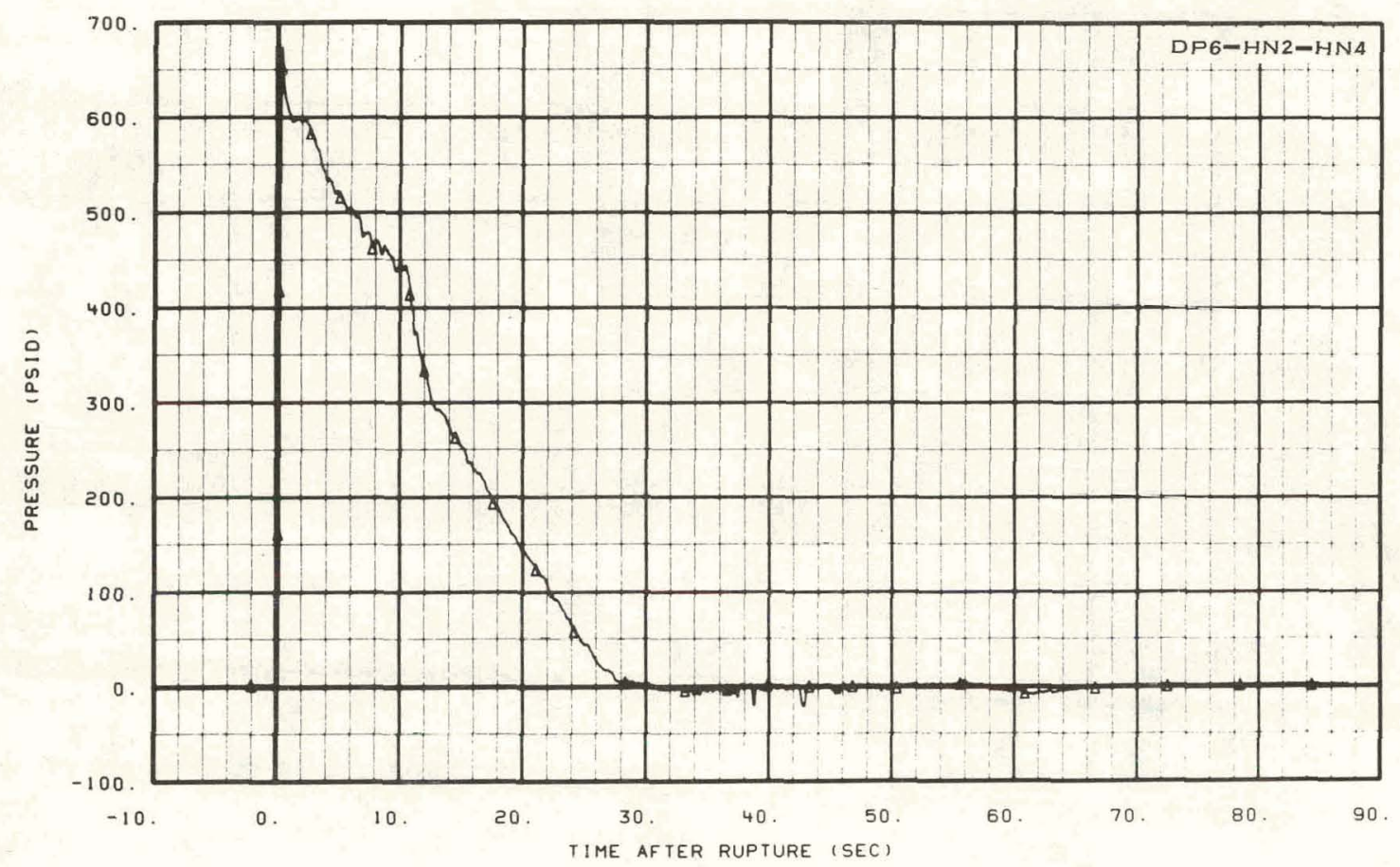

Fig. 69 Differential pressure across blowdown loop hot leg nozzle diverging section (DP6-HN2-HN4).

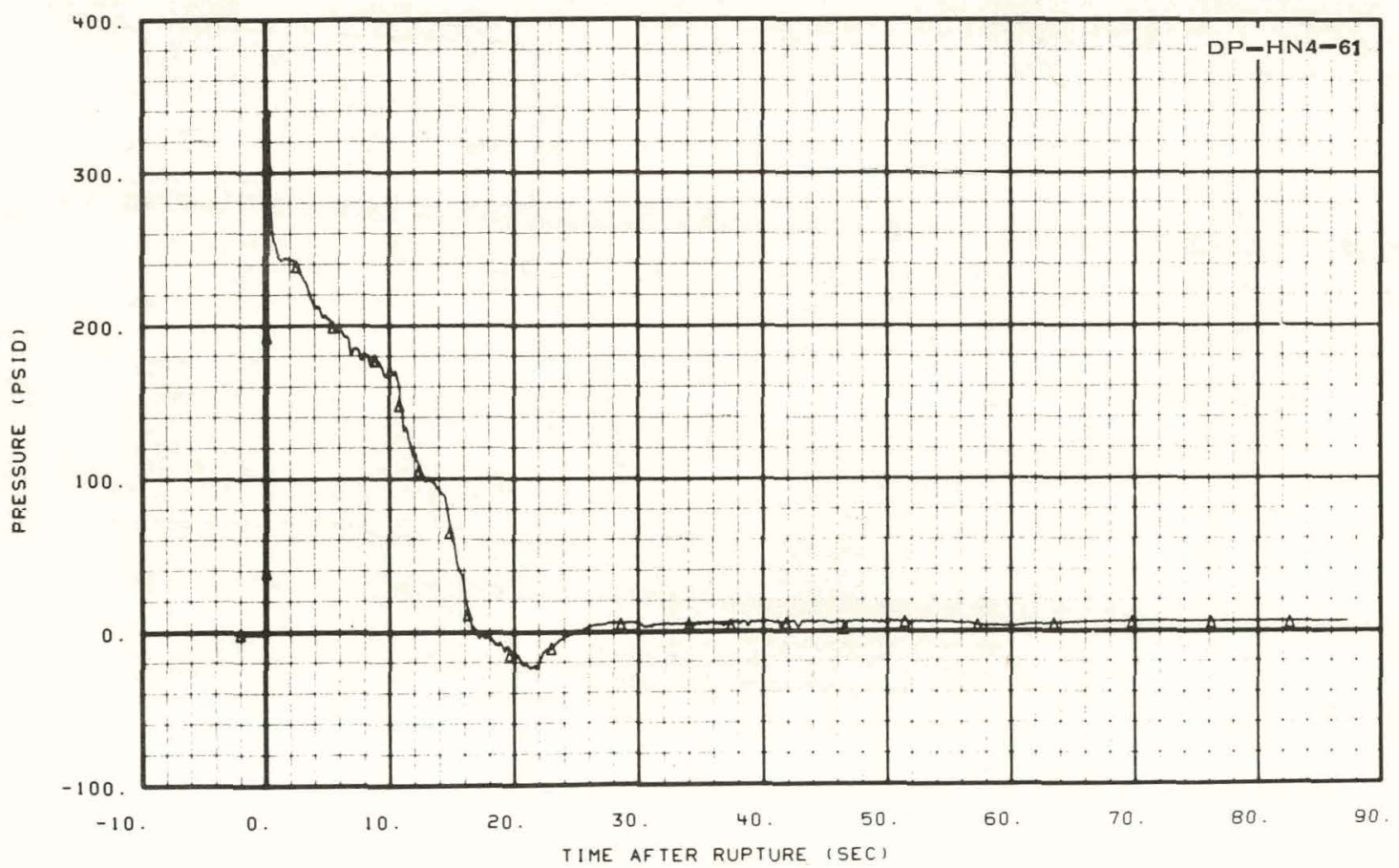

Fig. 70 Differential pressure across blowdown loop hot leg nozzle, Station 61 (DP-HN4-61). 


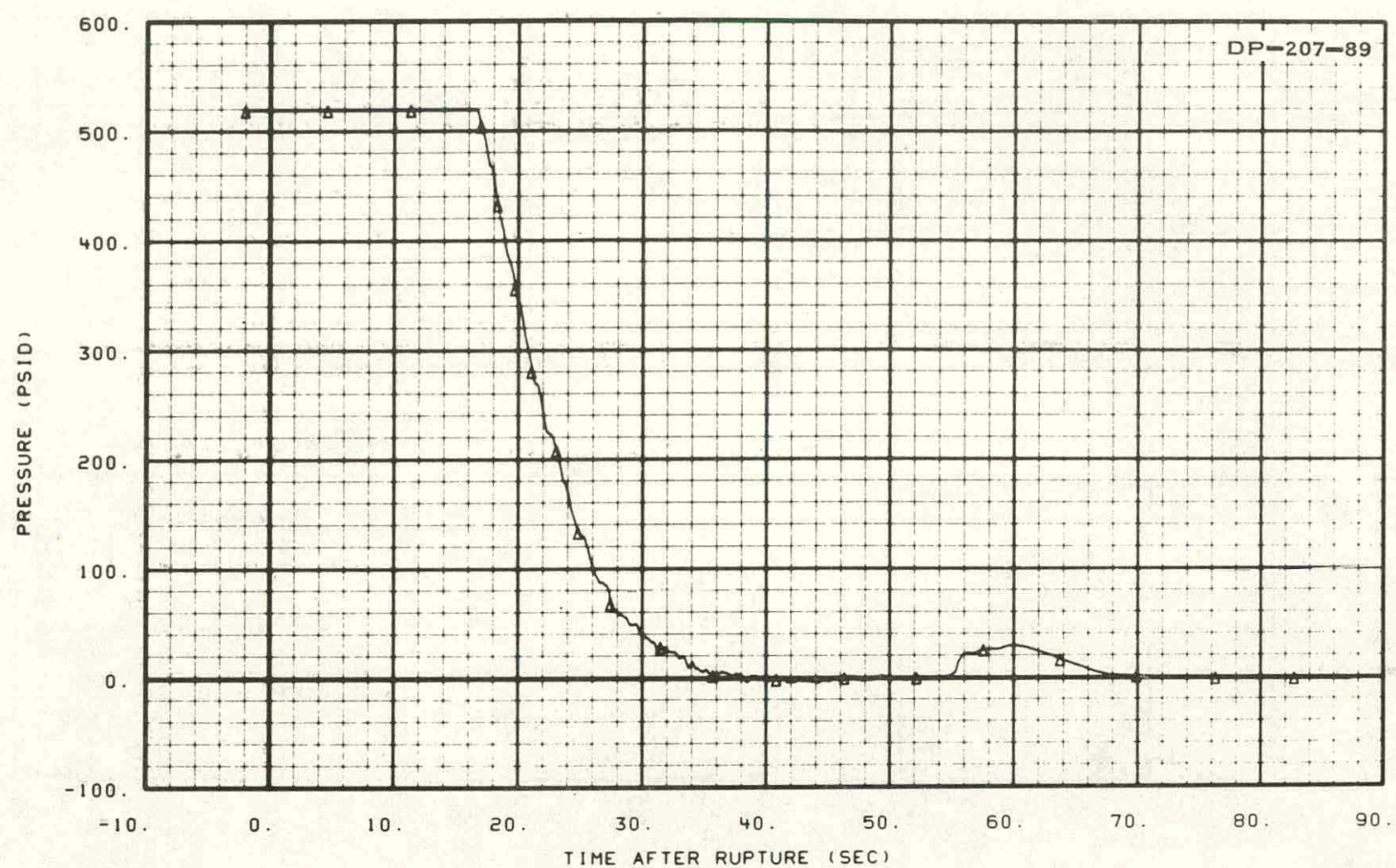

Fig. 71 Differential pressure between vessel upper plenum and pressure suppression tank vapor chamber (DP-207-89).

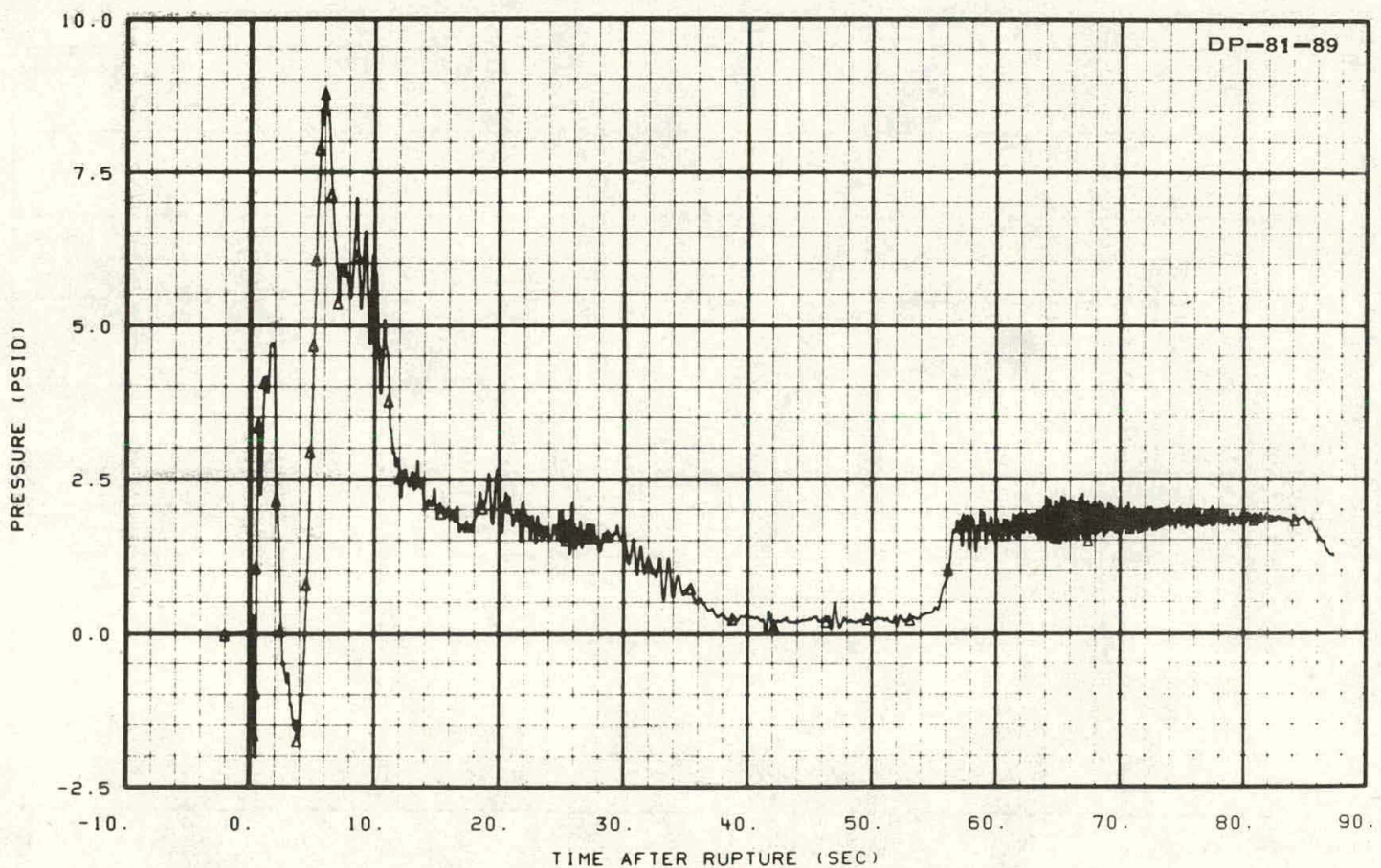

Fig. 72 Differential presśure between pressure suppression header and pressure suppression tank vapor chamber (DP-81-89). 


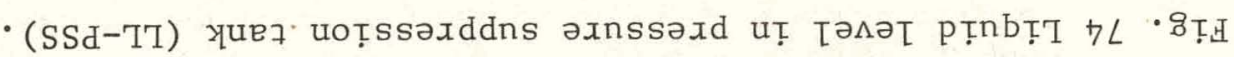

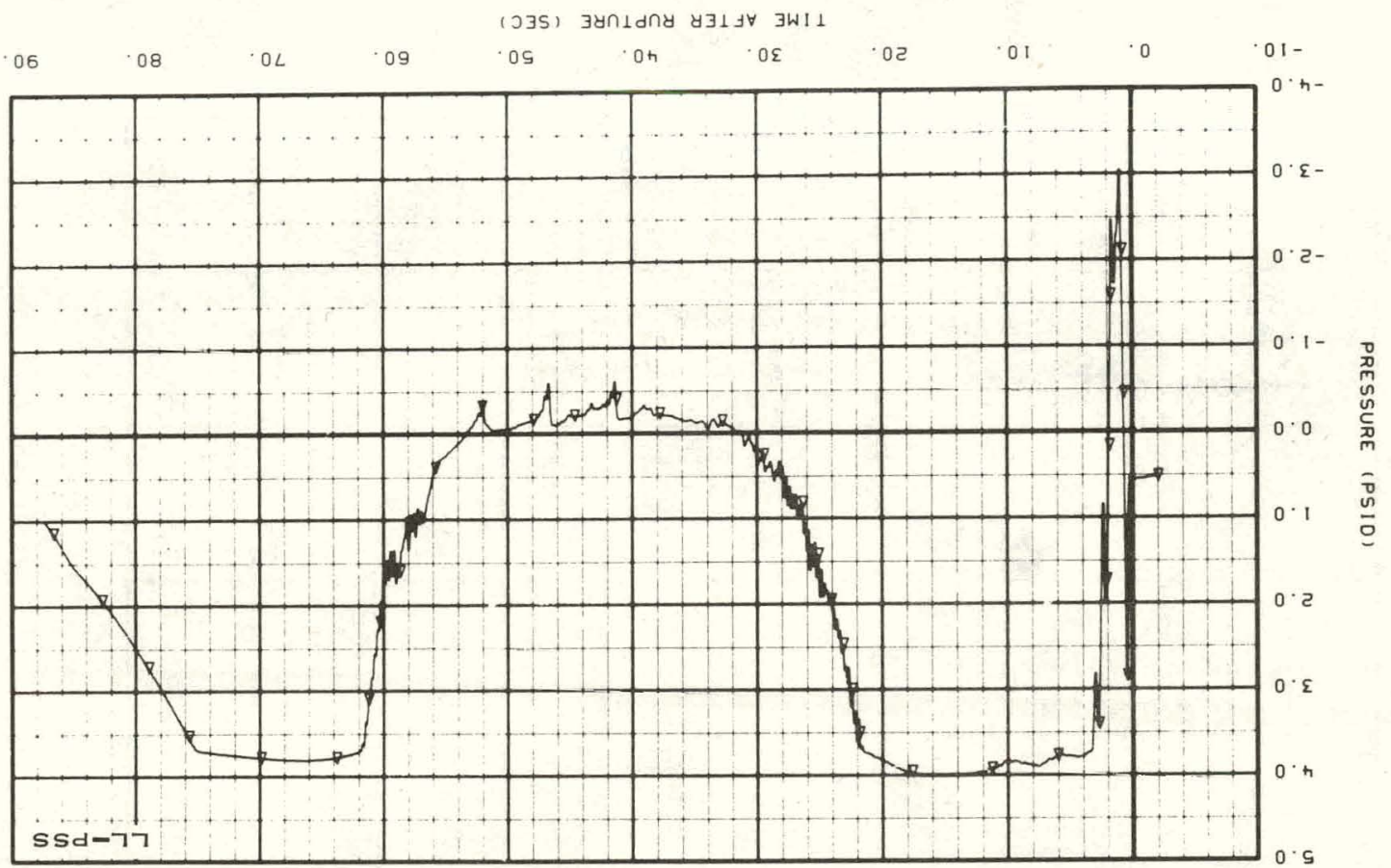

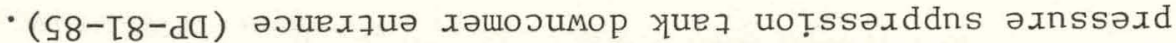

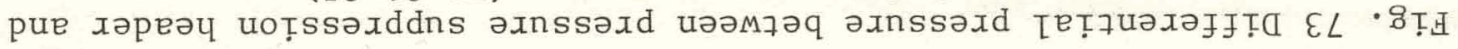

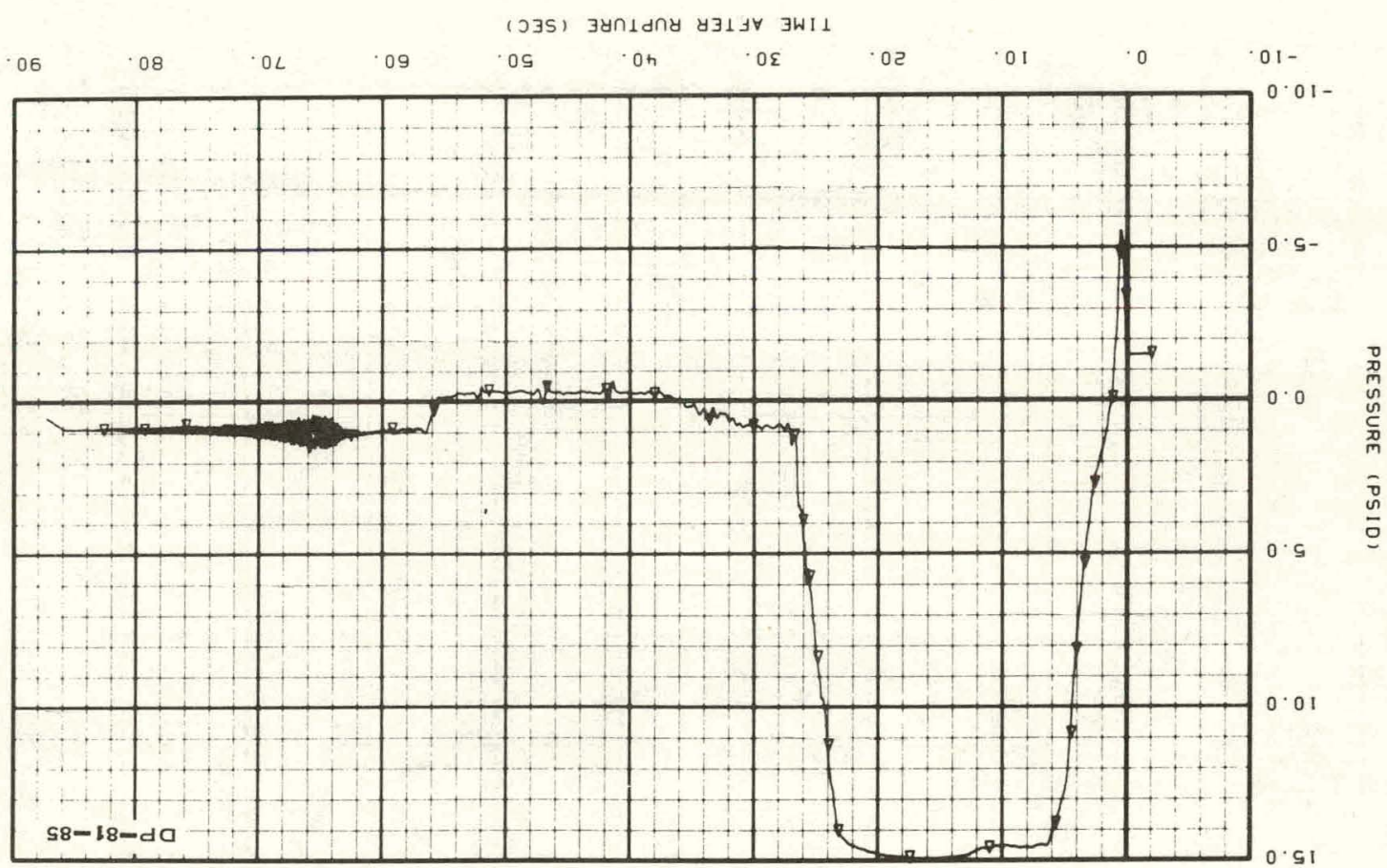




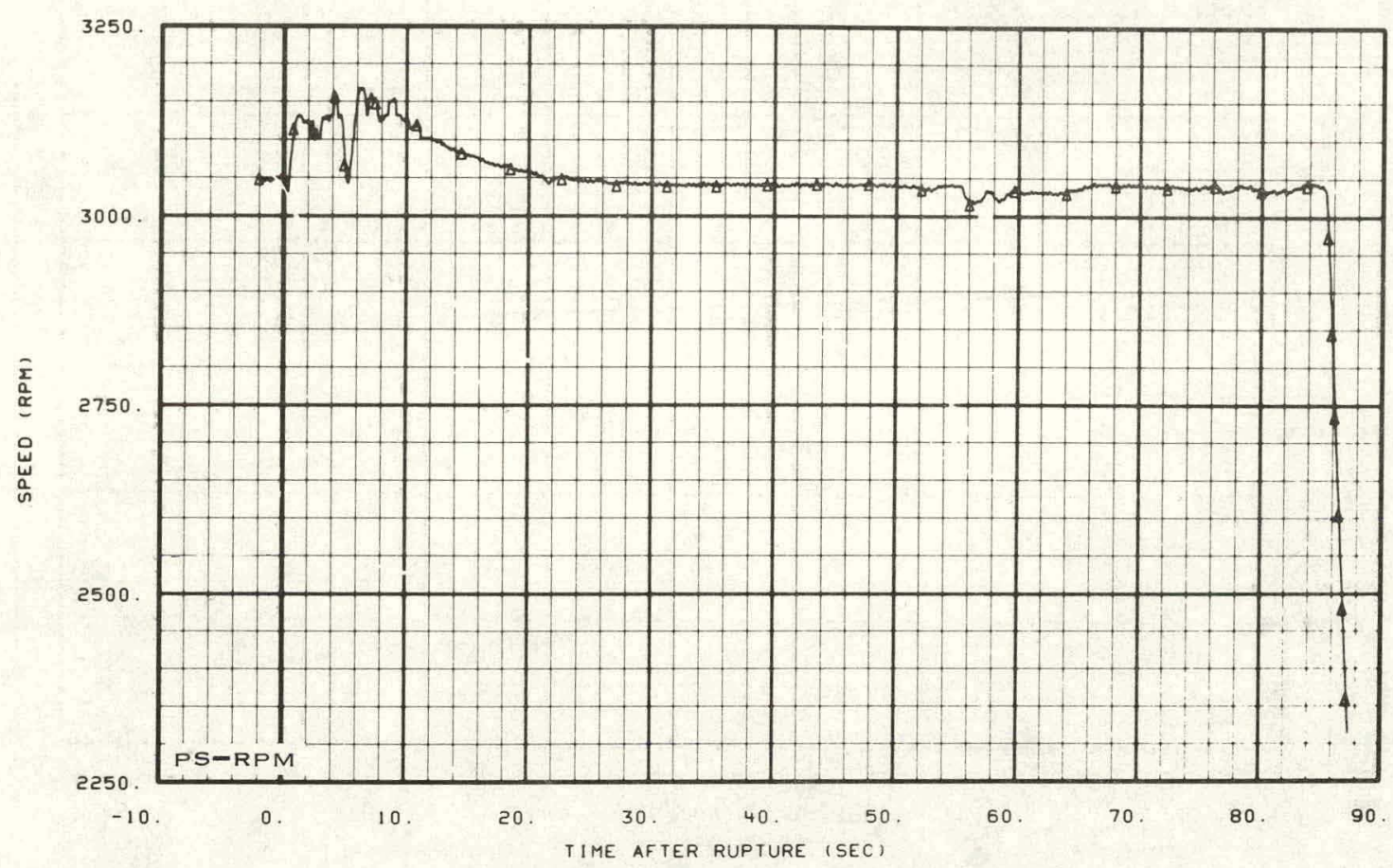

Fig. 75 Pump speed (PS-RPM).

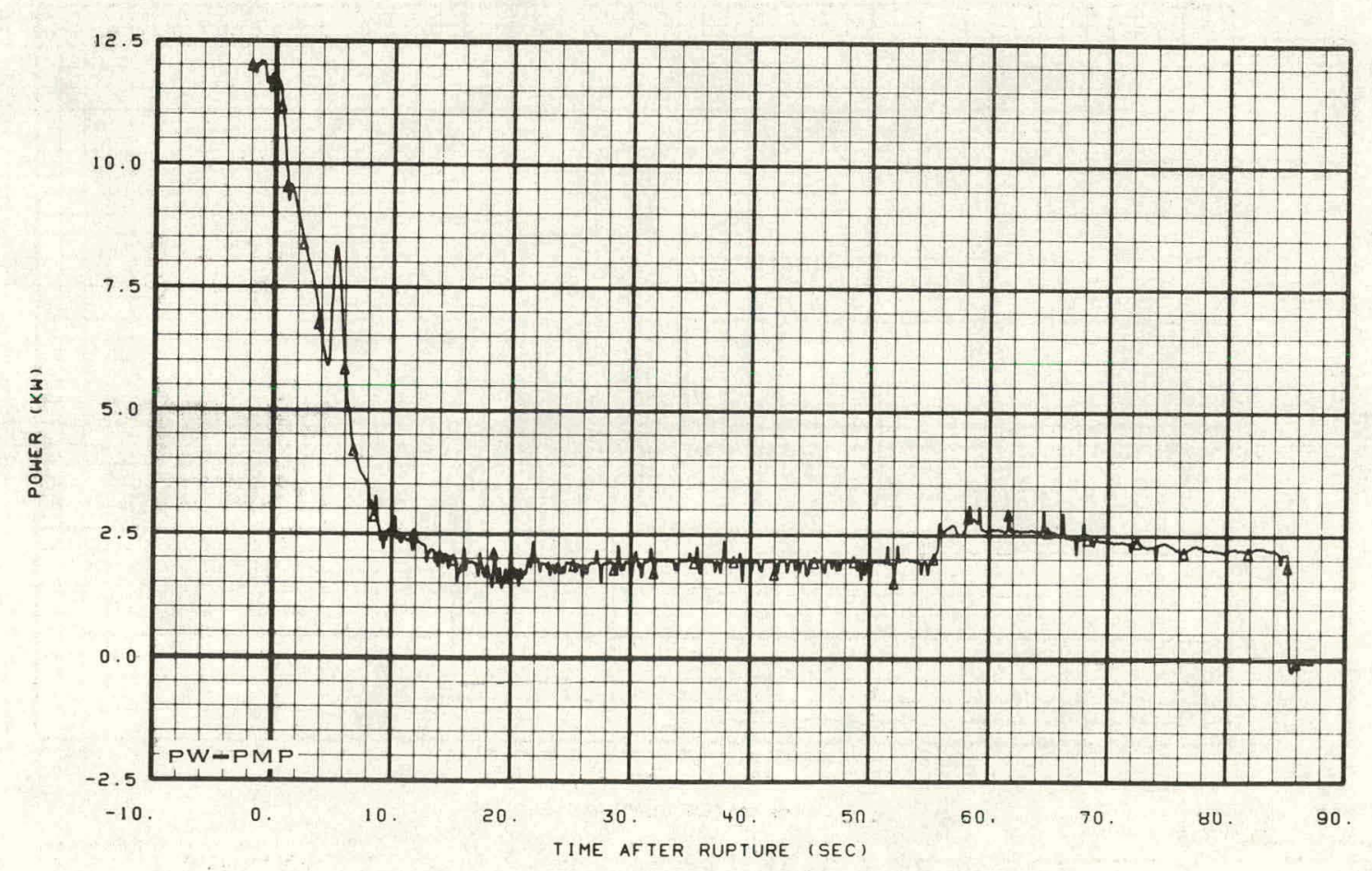

Fig. 76 Pump power (PW-PMP). 


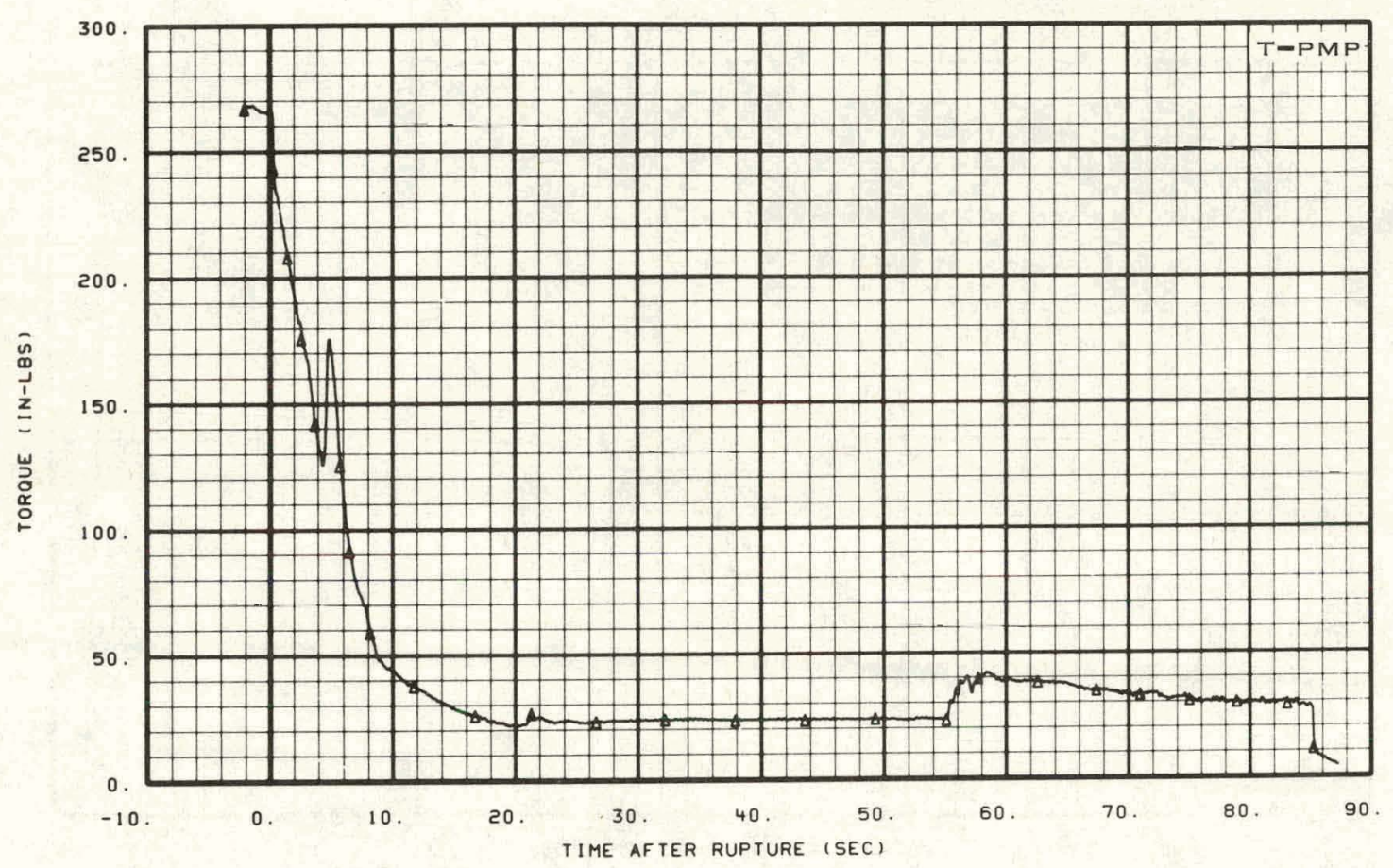

Fig. 77 Pump torque (T-PMP).

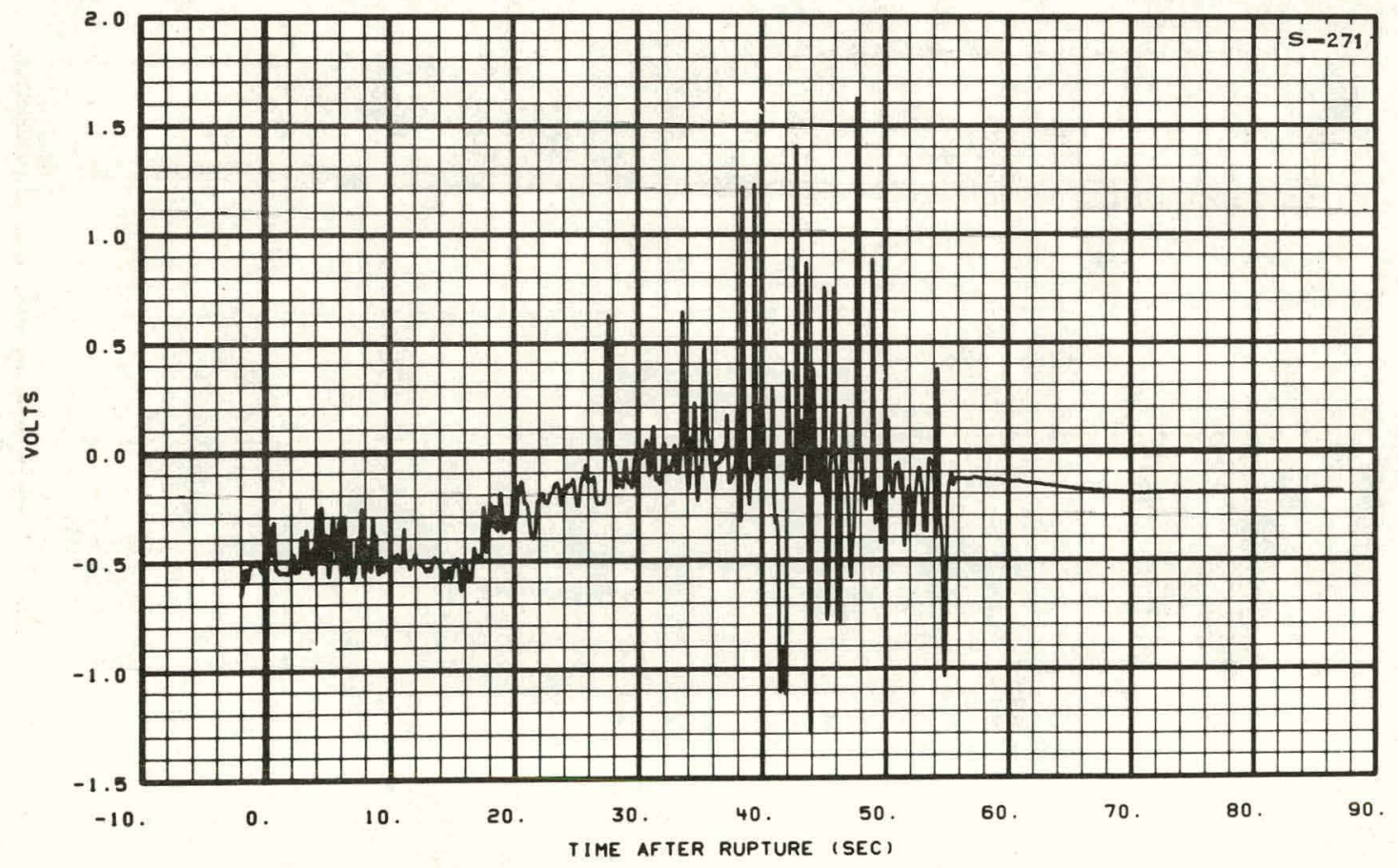

Fig. 78 Flow direction in downcomer gap (S-271). 


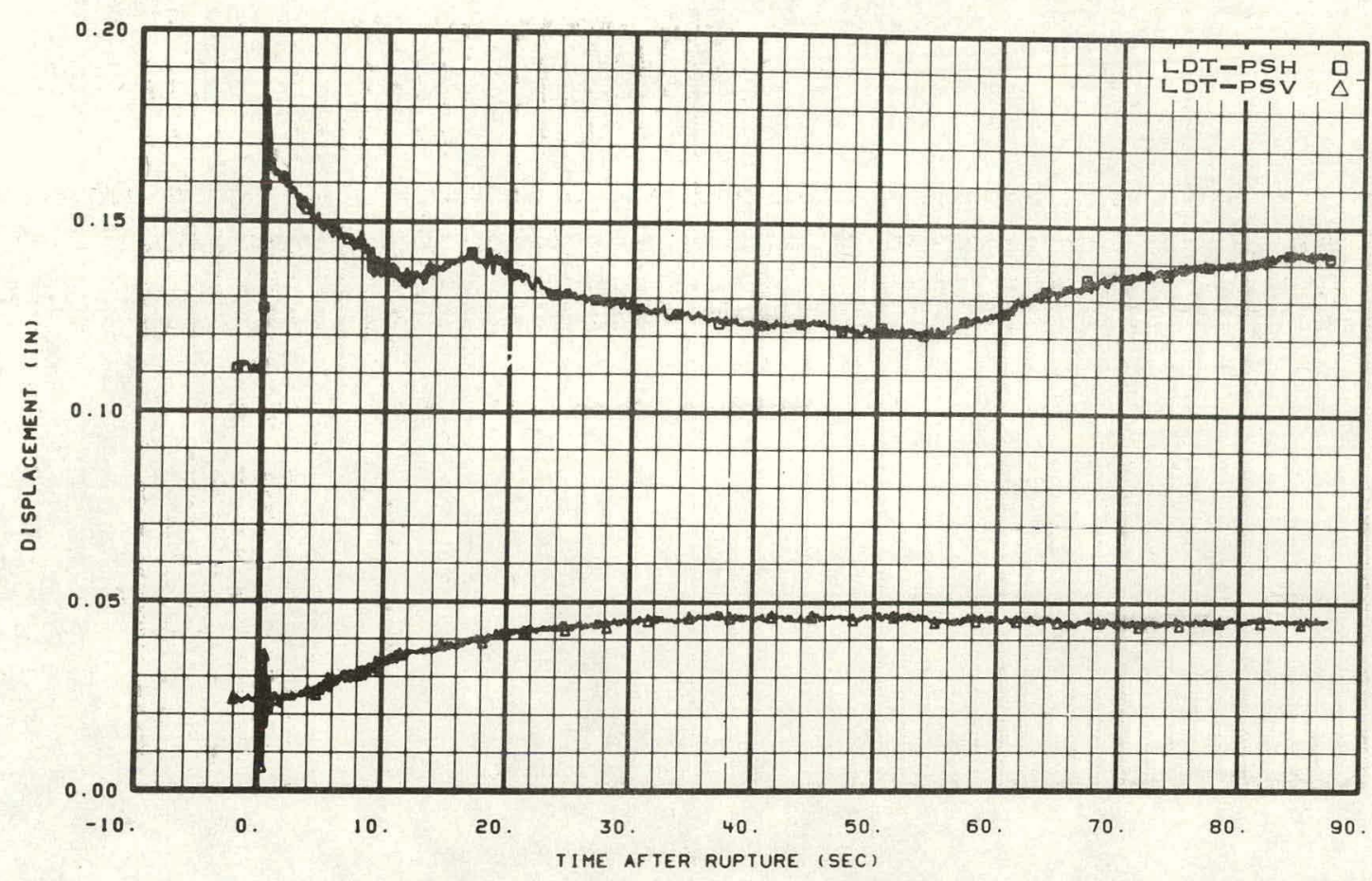

Fig. 79 Displacement of pressure suppression system. 


\section{REFERENCE}

1. S. A. Naff and P. A. Pinson, 1-1/2-Loop Semiscale Isothermal Test Program-Program and System Description in Support of Experiment Data Reports, ANCR-1143 (February 1974). 


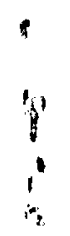

fi

1

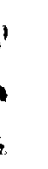

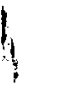

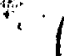

\&. 